\title{
QUANTIFYING THE ENVIRONMENTAL PERFORMANCE OF A STREAM HABITAT IMPROVEMENT PROJECT
}

\author{
A Thesis \\ presented to \\ the Faculty of California Polytechnic State University, \\ San Luis Obispo \\ In Partial Fulfillment \\ of the Requirements for the Degree \\ Master of Forestry Sciences in Environmental Management
}

by

Cody Morse

August 2018 
(C) 2018

Cody Morse

ALL RIGHTS RESERVED 
TITLE:

AUTHOR:

DATE SUBMITTED:

COMMITTEE CHAIR:

COMMITTEE MEMBER:

COMMITTEE MEMBER:
Quantifying the Environmental Performance of a Stream Habitat Enhancement Project

\author{
Cody Morse
}

August 2018

Yiwen Chiu, Ph.D.

Professor of Environmental Management

Brian Dietterick, Ph.D., P.H.

Director, Swanton Pacific Ranch

Jim Robins, M.S.

Principal and Senior Ecologist, Alnus Ecological 


\begin{abstract}
Quantifying the Environmental Performance of a Stream Habitat Improvement Project
\end{abstract}

\author{
Cody Morse
}

River restoration projects are being installed worldwide to rehabilitate degraded river habitat. Many of these projects focus on stream habitat improvement (SHI), and an estimated 60\%of the 37,000 projects listed in the National River Restoration Science Synthesis Program focus on SHI for salmon and trout species. These projects frequently lack a sufficient monitoring program or account for the environmental costs associated with SHI. The present study used life cycle assessment (LCA) techniques and topographic effectiveness monitoring to quantify environmental costs on the basis of geomorphic change. This methodology was a novel approach to assessing the cost-benefit relationship of SHI.

To test this methodology, two phases of the Lower Scotts Creek Floodplain and Habitat Enhancement Project (LSCR) were used as a case study. The LSCR was a SHI project installed along the northern coast of Santa Cruz County, California, USA. A limited scope LCA was used to quantify the life cycle impacts of raw material production, materials transportation, and on-site construction. Once these baseline results were produced, a topographic monitoring program was used to quantify the topographic diversity index (TDI) in pre- and post-project conditions. The TDI percent change was used to scale the baseline LCA results, which quantified the environmental impacts based on geomorphic change.

Phase II outperformed phase I. Phase I had greater cumulative environmental impacts and experienced a $7.7 \%$ TDI increase from pre- to post-project conditions. Phase II had $43 \%$ less cumulative environmental impacts and experienced a 7.9\% TDI increase from pre- to post-project conditions. The impacts in phase I were greater because of the amount of material excavated to create off-channel features, which were a key feature of the LSCR. A scenario analysis also was conducted within the LCA component of this study. The scenario analysis suggests that life cycle impacts could be reduced by $30 \%-65 \%$ by using the accelerated recruitment method in place of importing materials to build large wood complexes.

The results of this study suggest that managers may improve the environmental performance of SHI projects by: (1) using the accelerated recruitment method to introduce larger key pieces to the channel, reducing the need to import materials; (2) using nursery grown plants as opposed to excavating plants for revegetation; (3) minimizing fuel combustion in heavy equipment and haul trucks by ensuring clear access to the channel and streambank, using small engine equipment to clear access corridors during site preparation, running more fuel-efficient machinery or bio-fuel powered machinery, and by attempting to minimize haul distances by sourcing materials locally; and (4) utilizing a "franken-log" design (a ballasted LWC configuration with a rootwad fastened to the downstream end of a log) in LWCs which led to favorable TDI change. This study concluded that LCA could be a valuable tool for monitoring SHI and river restoration projects and that further research of the TDI analysis is justified.

Keywords: Life Cycle Assessment (LCA), Topographic Diversity Index (TDI), river restoration, stream habitat improvement, emissions, large-wood complex (LWC) 


\section{ACKNOWLEDGMENTS}

Many thanks to Dr. Yiwen Chiu for her patience and guidance on this project. Dr. Chiu pushed me to be a better scientist and professional. A special thank you to Brian Dietterick for getting me involved in this project and at Swanton Pacific Ranch. I acknowledge my well-spent time and invaluable collegial associations at Swanton Ranch, where I conducted this research, worked on three phases of the Lower Scotts Creek Habitat Enhancement Project and learned countless land management skills. Special thanks also to Jim Robins, who provided professional input on this project and helped to improve my writing skills. Many thanks to my mother, Cynthia Morse, for supporting my education. Special thank you to my father Kendall Morse and Laura Nolden for helping to edit this thesis document.

This work was supported by the National Institute of Food and Agriculture (Grant No. 46027), from the McIntire-Stennis Cooperative Forestry Program. This funding enabled the primary author Cody Morse to complete the requirements for a graduate degree in forestry sciences from California Polytechnic State University - San Luis Obispo. This research took place at Swanton Pacific Ranch which is owned by Cal Poly Corporation and managed by the College of Agriculture, Food and Environmental Sciences. Swanton Pacific Ranch is a working ranch that conducts research and operations in organic agriculture, forestry, livestock management, and watershed management. I am deeply grateful for the opportunity and hope to stay connected to Cal Poly and the Swanton Community. 


\section{TABLE OF CONTENTS}

$\begin{array}{rll} & \text { Page }\end{array}$

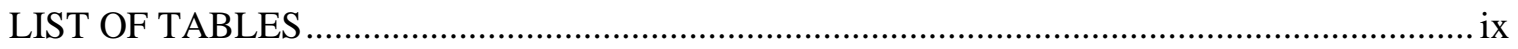

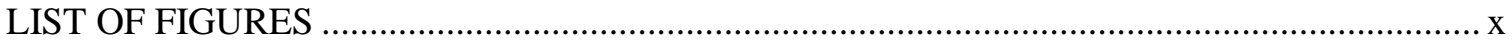

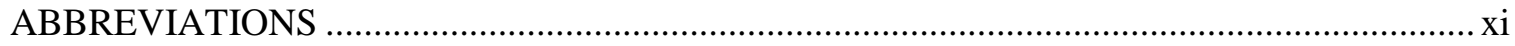

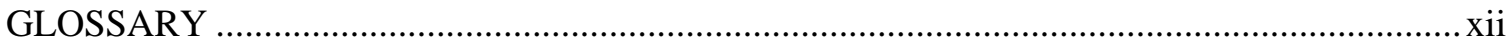

CHAPTER

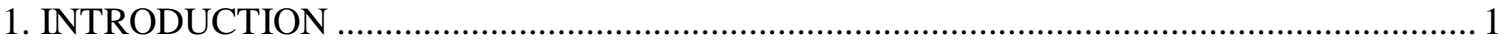

1.1 River Restoration Background .............................................................................. 1

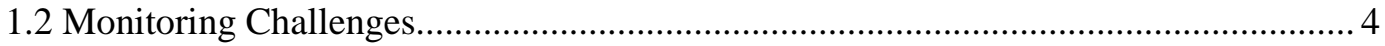

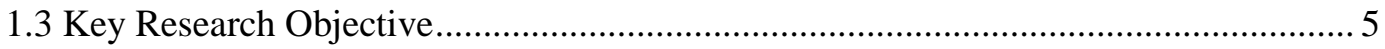

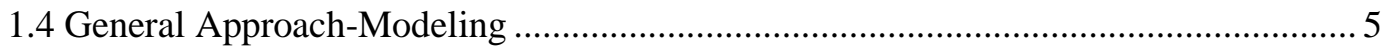

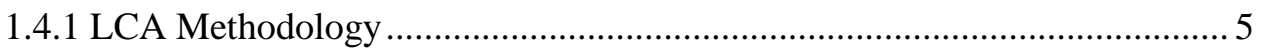

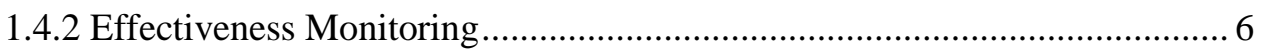

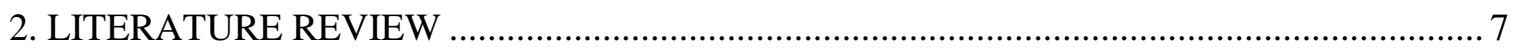

2.1 LCA Applications in Forest Harvest and Management Scenarios................................ 8

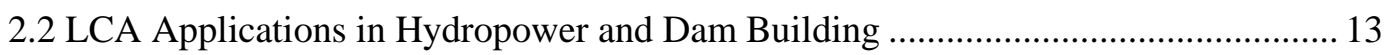

2.3 LCA Applications in Construction and Materials Production ................................... 15

2.4 Applying ISO Framework to River Restoration .................................................... 18

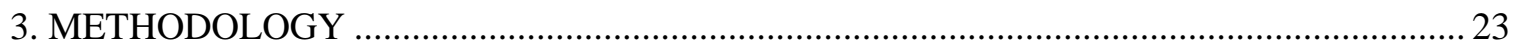

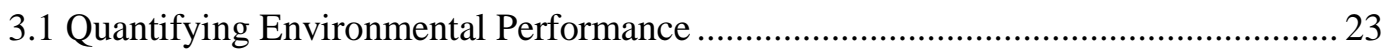

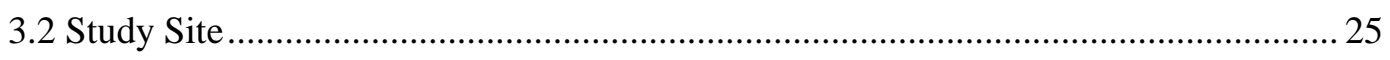

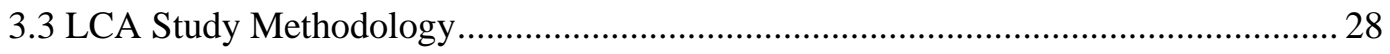

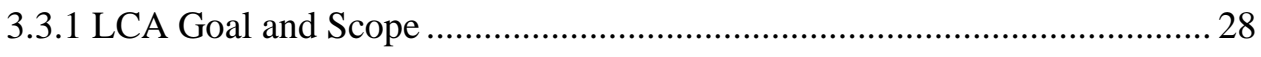

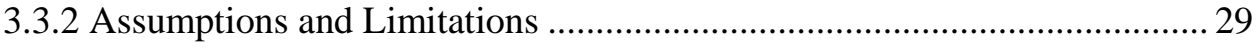

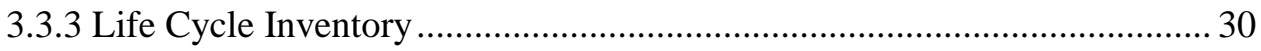

3.3.4 Life Cycle Impact Assessment............................................................... 34

3.3.5 Key Contributor Analysis ........................................................................ 35

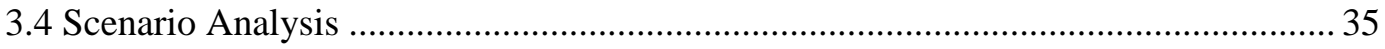

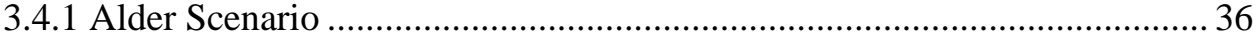

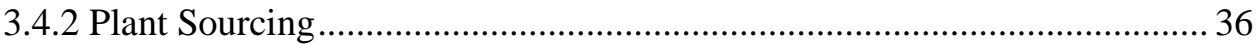

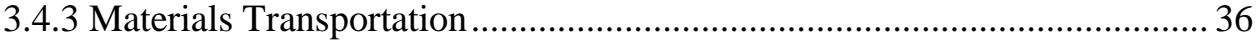

3.5 Quantifying Environmental Performance …............................................................ 37

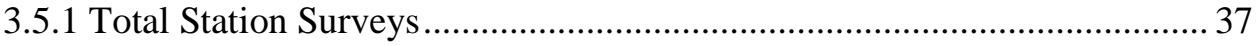


3.5.3 Topographic Diversity Index Percent Change .......................................... 38

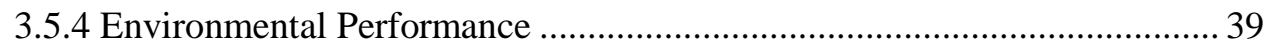

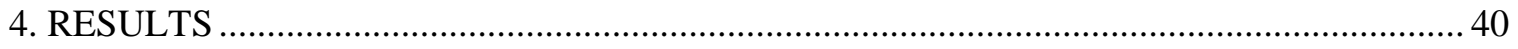

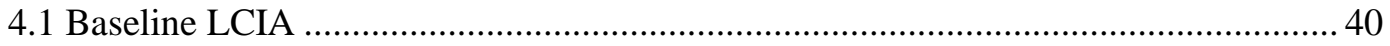

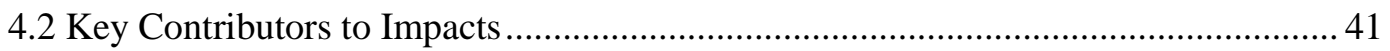

4.2.1 Key Contributors to Impacts in Phase I ................................................. 41

4.2.1.1 Human Health-Carcinogenics.................................................... 41

4.2.1.2 Resource Depletion-Fossil Fuels .............................................. 41

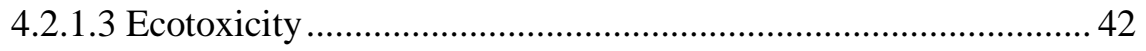

4.2.1.4 Photochemical Ozone Formation.............................................. 42

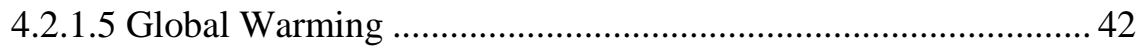

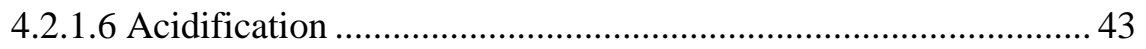

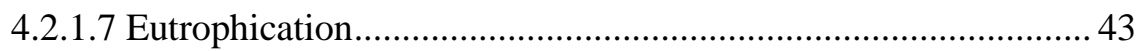

4.2.1.8 Human Health- Non-Carcinogenics.......................................... 43

4.2.1.9 Respiratory Effects ............................................................... 43

4.2.1.10 Ozone Depletion .................................................................. 44

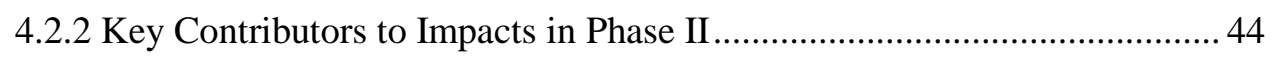

4.2.2.1 Human Health-Carcinogenics.................................................. 44

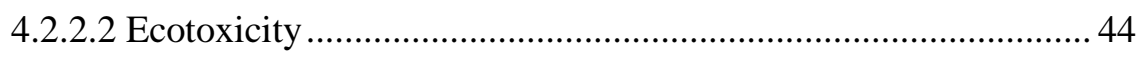

4.2.2.3 Global Warming ................................................................ 45

4.2.2.4 Resource Depletion -Fossil Fuels ............................................ 45

4.2.2.5 Photochemical Ozone Formation............................................... 45

4.2.2.6 Human Health- Non-Carcinogenics.......................................... 45

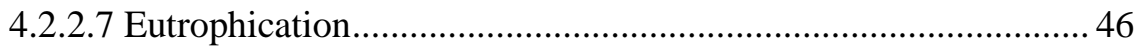

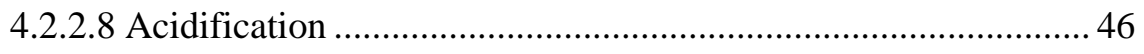

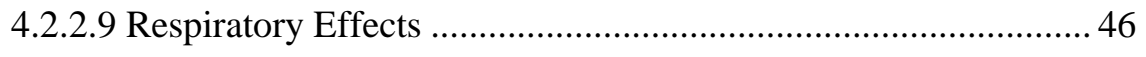

4.2.2.10 Ozone Depletion ................................................................... 47

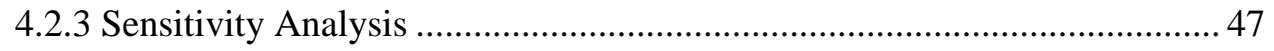

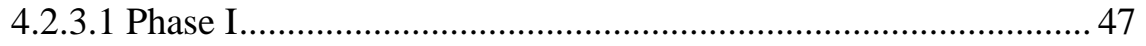

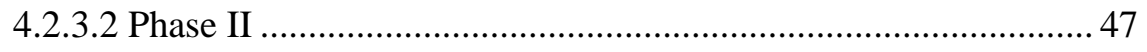

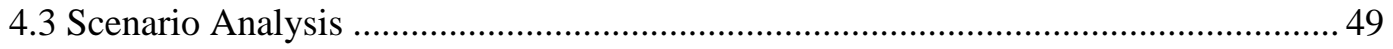

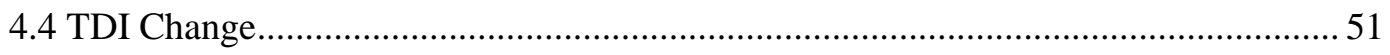

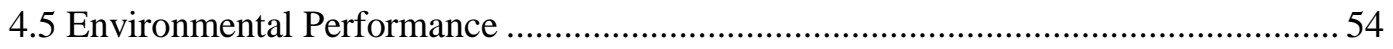




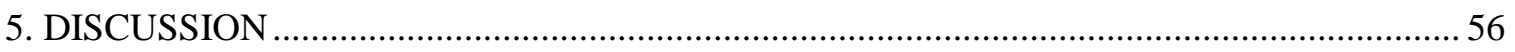

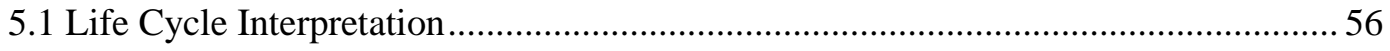

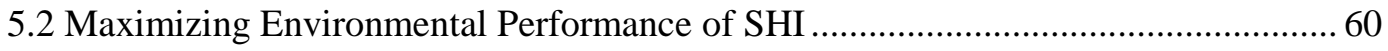

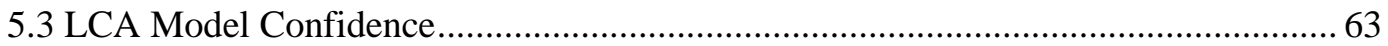

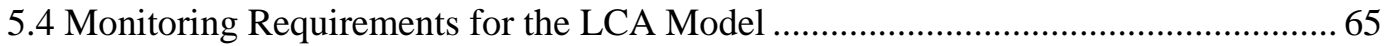

5.5 Data Requirements for TDI Effectiveness Monitoring ........................................... 67

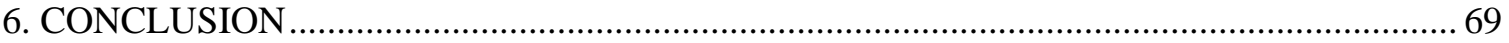

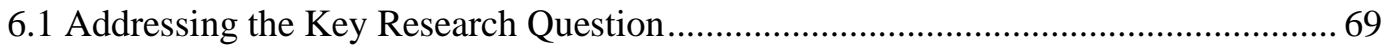

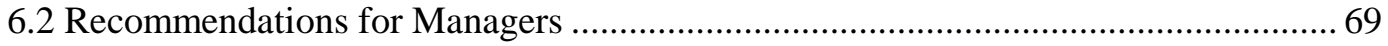

6.2.1 Accelerated Recruitment Method ............................................................. 69

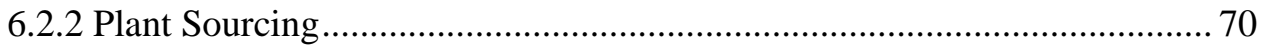

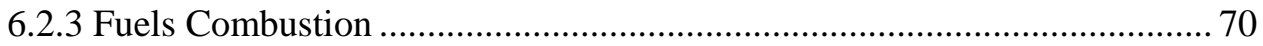

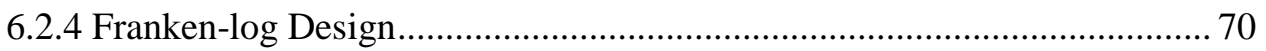

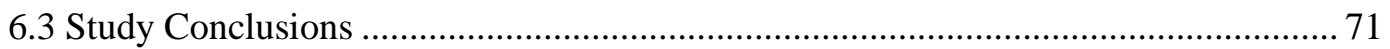

6.3.1 LCA Monitoring Applicability …............................................................ 71

6.3.2 Functional Unit Applicability ............................................................. 71

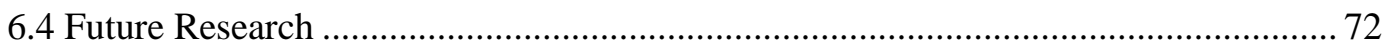

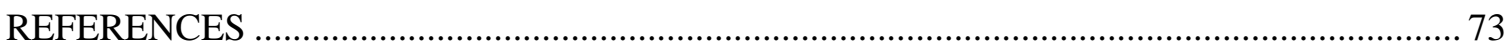

APPENDIX

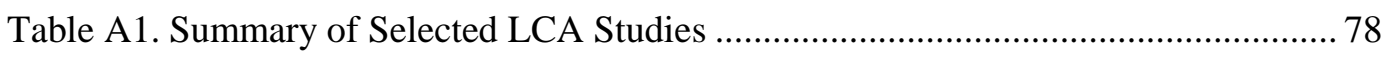

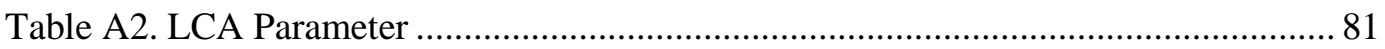

Table A3. Phase I Sensitivity Analysis Results ............................................................ 82

Table A4. Phase I Sensitivity Analysis Results ............................................................. 82

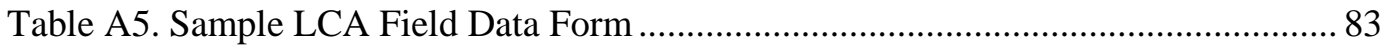




\section{LIST OF TABLES}

Table

1. LCI inputs and technical notes for raw material production phase of the LSCR.

2. LCI inputs and technical notes for the transportation phase of the LSCR.

3. LCI inputs and technical notes for on-site construction phase of the LSCR

4. Summary of scenario analysis by restoration phase.

5. Non-normalized and normalized LCIA results for restoring one meter of stream.

6. Area (ft2) and TDI value for each elevation category in phase I and II of the LSCR.

7. The impact assessment results scaled to reflect a $1 \%$ TDI increase functional unit in both phase I and II.

8. An outline of tasks associated with LCA data collection, modeling, an incorporation with a geomorphic effectiveness monitoring program. 66

9. An outline of tasks associated with establishing a geomorphic effectiveness monitoring program. 


\section{LIST OF FIGURES}

Figure

Page

Figure 1. Product system diagram for the stream habitat improvement (SHI) process with the proposed cradle-to-gate system boundaries.

Figure 2. A schematic diagram of the LCA methodology used to quantify the environmental performance of SHI projects.

Figure 3. Location of Scott's Creek and phase I and II of the Lower Scotts Creek Floodplain and Habitat Enhancement.

Figure 4 CCC Coho Salmon spawning adult estimates for Scotts creek (excerpted from NMFS, 2012). .28

Figure 5. Key contributors to environmental impacts in Human Health-Carcinogenics (HHC), Photochemical Ozone Formation (POF), Global Warming (GW), Acidification (AC), Ecotoxicity (EU), Eutrophication (EU), Human Health Non-Carcinogenics (HHNC), Respiratory Effects (RE), Resource Depletion (RE), and Ozone Depletion (OD) in Phase I (P1) and Phase II (P2).

Figure 6. Quantifies the overall environmental impacts from the baseline, Alder 50\% (AS 50\%), Alder 100\% (AS 100\%), Plant Sourcing (PS), and Materials Transportation (MT) scenarios......50

Figure 7. DEM of study reach channels for phase I (top) and phase II (bottom), pre-project survey is shown on the left, post-project survey is shown on the right. .53

Figure 8. A picture of a franken-log LWC configuration. .54

Figure 9. A view looking upstream at LWC 3 in phase II showing the multi-stemmed alder and LWC beneath. Most readily identifiable is the rootwad of LWC 3 in phase II on the left of the picture. 


\section{ABBREVIATIONS}

LCA Life Cycle Assessment

SHI Stream habitat improvement

LWC Large Wood Complex

LSCR Lower Scotts Creek Floodplain and Habitat Enhancement Project

AS

PS

MT

TDI

ISO

LCI

LCIA Life Cycle Impact Assessment

DEM Digital Elevation Models

CCC Central California Coast

DBH Diameter at Breast Height

TIN Triangular Irregular Network
Alder Scenario

Plant Sourcing Scenario

Materials Transportation Scenario

Topographic Diversity Index

International Organization for Standardization

Life Cycle Inventory 


\section{GLOSSARY}

Life Cycle Assessment (LCA) - an environmental management technique which quantifies the environmental impacts over the life cycle of a product

Stream Habitat Improvement (SHI) - river restoration practices focused on improving stream and floodplain habitat for fish or other threatened species

Environmental Impacts - a LCA term which represents the potential impacts from the use of resources and/or the environmental consequence of releases (used interchangeably with “impacts”)

Life Cycle Inventory Analysis (LCI) - involves data collection and calculation procedure to quantify relevant inputs and outputs of a product system

Life Cycle Impact Assessment (LCIA) - evaluates the significance of potential environmental impacts using the LCI results

Impact Assessment Methodology - a tool used to in LCIA to assign emissions to various environmental impact categories

Unit Process - smallest element considered in the LCI for which input and output data are quantified

System Boundaries - asset of criteria specifying which unit processes are part of a product system 


\section{Introduction}

\subsection{River Restoration Background}

In an ecological context, river restoration refers to a variety of practices which aim to improve key ecosystem functions, often in support of a species or community. River restoration is widely practiced across the world, especially in developed countries (Kail et al., 2007; Roni et al., 2008). In the U.S. alone, over 37,000 river restoration projects were implemented between 1990 and 2003. The annual number of projects increased from approximately 400 in 1990 to approximately 5,500 in 2003 and cost on average one billion dollars per year (Bernhardt et al., 2005). Increased river restoration in the U.S. was catalyzed in part by the listing of many Pacific salmon populations (Oncorhynchus spp.) as threatened or endangered under the U.S. Endangered Species Act (Roni et al., 2010). An estimated $60 \%$ of the aforementioned 37,000 projects aimed to improve habitat for salmon and trout in the Pacific Northwest and California (Bernhardt et al., 2005; Roni et al., 2010). The popularity of river restoration (Morandi et al., 2014) and the lack of information on how river restoration practices may contribute to anthropogenic pollution, underscore the need for further study to quantify the environmental impacts of the river restoration process.

In 2010, the California Environmental Quality Act began requiring state and local agencies to conduct or support analyses which address the greenhouse gas emissions associated with a proposed project (Association of Environmental Professionals, 2010). Life cycle assessment (LCA) is a tool that can be used to address this aspect of impact analysis. LCA is an environmental management technique which quantifies the environmental impacts over the life cycle of a product or service (ISO, 2006).

LCA measures environmental impacts over a range of impact categories including, but not limited to, global warming potential, acidification, or eutrophication. Environmental impacts are 
typically measured from the time raw materials are acquired to the end of life of a product or service. Each impact category is measured in a way that relates the emissions to a single refence unit. For instance, global warming potential is measured using $\mathrm{CO}_{2}$ equivalence $\left(\mathrm{kg} \mathrm{CO}_{2}\right.$ eq.). During the life cycle impact assessment phase of LCA any emission which contributes to the global warming potential is converted to $\mathrm{kg}$. $\mathrm{CO}_{2}$ eq. and reported in terms global warming potential. This study will focus on applying LCA, techniques to measure the environmental impacts in ten impact categories (photochemical ozone formation, acidification, global warming, eutrophication, respiratory effects, human Health-non-carcinogenics, human healthcarcinogenics, ecotoxicity, ozone depletion, and resource depletion-fossil fuels) associated with the implementation of a stream habitat improvement (SHI) project, a common type of river restoration project. Although LCA is used in a wide variety of other fields, an extensive literature review suggests that LCA has never been applied previously to a river restoration project.

LCA has been applied to manufacturing (López Gayarre et al., 2015; Gan et al., 2016a), renewable energy production (Suwanit and Gheewala, 2011; Turney and Fthenakis, 2011; Varun et al., 2012; González-García et al., 2013b; Zhang et al., 2014), and forest product production (Dias and Arroja, 2012; Cambria and Pierangeli, 2012; González-García et al., 2013a, 2014a; Han et al., 2015), among other fields. To quantify the environmental impacts of river restoration, this study proposed using a cradle-to-gate LCA (including material sourcing, transportation, and project construction) for two phases of a SHI project, which were completed in fall of 2015 and 2016, respectively. These projects were conducted on Cal Poly's Swanton Pacific Ranch, situated on the West coast of North America, in northern Santa Cruz County, California.

SHI projects are arguably the most common river restoration projects. The main goal of these projects is to improve habitat for salmon and trout in the Pacific Northwest and California (Bernhardt et al., 2005; Roni et al., 2010). Techniques for SHI vary, but commonly include 
riparian planting, exclusion of livestock, removal of barriers to fish passage, erosion control, floodplain habitat improvements, and placing instream structures to create or improve fish habitat (Roni et al., 2010, 2014; Howson et al., 2012; Carah et al., 2014). SHI is a long-standing practice. Using instream structures to improve habitat for fish been documented as early as the 1880's (Thompson and Stull, 2002). The popularity and historical use of SHI practices, have led to the publication of numerous manuals and books which guide managers on design and implementation (Roni et al., 2002).

In California, numerous agencies and stakeholders support SHI projects. For instance, the California Department of Fish and Wildlife published the fourth edition of the California Salmonid Stream Habitat Restoration Manual in 2010 to serve as a guide for SHI projects. This manual provides a list of basic structural materials including gabions, logs, rootwads, and boulders (Flosi et al., 2010). Often these materials are used to construct large-wood complexes (LWCs) or other engineered structures to improve habitat conditions (Gallagher et al., 2012; Carah et al., 2014). Improving habitat conditions in California is a common goal of river restoration projects because approximately $34 \%$ of perennial streams in California are classified as degraded (Swamp PSA, 2015). Sources of this degradation include hydropower, agriculture, timber harvesting, wood removal, and mining (Nehlsen et al., 1991; Carah et al., 2014). These and other activities have led to a variety of disturbances including higher degrees of channelization, channel erosion, and excessive sediment deposits. SHI projects often aim to remediate these disturbances by introducing structures which may alter channel depth or substrate dynamics, river velocity, stream cover, high-flow refuge habitat, and processes that affect oviposition (Howson et al., 2012). 


\subsection{Monitoring Challenges}

Although abundant information exists on the design and implementation of river restoration, project monitoring has been and remains a substantial challenge (Bernhardt et al., 2005; Katz et al., 2007; Palmer et al., 2007; Rumps et al., 2007). Rumps et al., (2007) interviewed 47 project managers in the Pacific Northwest, of whom $70 \%$ reported successful projects, although, $43 \%$ were unable to provide any success criteria. Although effectiveness monitoring programs are more common today, river restoration projects continue to be implemented without adequate monitoring programs. Furthermore, many monitoring programs lack the reproducibility required to inform similar future projects (Tompkins and Kondolf, 2007). Incorporating LCA into a monitoring program would allow for a reproducible framework that could be applied to SHI projects, and on a broader scale, to all river restoration projects.

Although monitoring programs still face challenges, numerous studies have tracked the success of restoration projects. When successful monitoring programs were established, they tended to focus on the effects of restoration projects on fish abundance. These programs typically demonstrated a positive response (Cederholm et al., 1997; Solazzi et al., 2000; Kail et al., 2007; Nagayama and Nakamura, 2010; Whiteway et al., 2010; Roni et al., 2010; Howson et al., 2012; Jong and Cowx, 2016), but occasionally demonstrated little or no response (Stewart et al., 2009; Koljonen et al., 2013). Some monitoring programs focused on geomorphic (structure or shape of the river channel) aspects of restoration projects (Tompkins and Kondolf, 2007; Carah et al., 2014; Poppe et al., 2016). Other monitoring programs used a combination of indicators that included fish abundance and geomorphic aspects along with macroinvertebrate populations and aquatic fauna (Gerhard and Reich, 2000; O’Neal et al., 2016; Pilotto et al., 2016). Although there is a variety of effectiveness monitoring programs, many of these monitoring programs fell short of addressing the environmental impacts that may be associated with implementation of SHI. 


\subsection{Key Research Objective}

To address the environmental performance of SHI projects, this study sought to answer the following key research question: Can we quantify the environmental costs of river restoration based on geomorphic change? The specific goals of this research were to: (1) quantify the environmental impacts of installing a SHI project; (2) identify the key contributors to the environmental impacts from an SHI project; (3) use topographic data to quantify the environmental performance of an SHI project; (4) document how managers may use this framework to improve the environmental performance of SHI projects.

\subsection{General Approach - Modeling}

This study used the Lower Scotts Creek Stream Floodplain and Habitat Enhancement Project (LSCR) as a case study. The LSCR used LWCs (large wood complex), floodplain connections, and riparian planting to conduct SHI (Cook, 2016). This methodology coupled LCA and topographic effectiveness monitoring to quantify the environmental performance of the LSCR, a study conducted in two phases.

\subsubsection{LCA Methodology}

This study quantified the environmental impacts associated with raw material production, transportation to the site, and on-site construction (cradle-to-gate) of phases I and II of the LSCR. An environmental impact profile was produced for the baseline conditions in both phase I and II. These baseline data helped identify the key contributors to environmental impacts in both phases I and II. Furthermore, a scenario analysis quantified the environmental impact from using (1) two alder scenarios (AS 50\% and AS 100\%) in which in-situ alders were added as unanchored largewood to the channel; (2) a plant sourcing scenario (PS), which varied the methods used to conduct revegetation in disturbed areas; and (3) a materials transportation (MT) scenario which increased material transport distances. 


\subsubsection{Effectiveness Monitoring}

To assess the effectiveness of the LSCR, topographic surveys were conducted for pre- and postproject conditions in both phases I and II. These topographic surveys were used a total station (optical surveying equipment) to assess changes in the physical habitat that may have resulted from project installations, particularly from LWCs. These data were used to model the topographic diversity index (TDI), which quantified the channel complexity before and after restoration was conducted. TDIs were used to assess major changes in habitat types and to develop an approach that integrates LCA results to quantify the environmental performance of the LSCR. 


\section{Literature Review}

River restoration encompasses a wide range of practices. It can be is broadly defined as an attempt to return river ecosystem functions to pre-disturbance conditions (Kauffman et al., 2011). Along the West Coast of the USA, most river restoration projects aim to improve habitat for threatened endangered salmonids (Bash and Ryan, 2002; Bernhardt et al., 2005). Frequently, this style of river restoration aims to increase the amount and density of downed wood in the channel, either by improving riparian conditions such that there will be a natural input of wood to the channel, or by artificially increasing instream wood densities by placing wood structures in the channel. Inputs of large wood can increase slow-water areas by creating backwaters, pools, side-channels, eddies, and floodplain access. Restoration efforts that introduce large wood aim to mimic the ecosystem services large wood provides, which can increase the amount and quality of crucial over-wintering habitats and summer low-flow habitats (Gallagher et al., 2012; Carah et al., 2014).

River restoration using large wood has occurred for decades (Thompson, 2006), especially in North America where there is a great deal of interest in restoring historic salmon fisheries (Carah et al., 2014). In fact, the California Fisheries Restoration Grant Program has spent approximately 180 million dollars on restoration activities - not limited to large wood projects - from 1981 to 2012 (Gallagher et al., 2012). In a similar period, over 37,000 river restoration projects have been implemented across the U.S. (Bernhardt et al., 2005).

Typically, instream structures that incorporate large wood are built using imported logs or by directly falling riparian trees into the channel. These LWCs often incorporate logs, boulders, rebar, steel cabling, epoxy, and other engineered materials. Constructing these wood features often requires the use of heavy machinery and other small-engine equipment: such as, log skidders, excavators, front-loaders, chainsaws, dump trucks, and other machinery to manipulate and place hefty materials (Kail et al., 2007; Carah et al., 2014). The effectiveness and the design of these 
wood structures has been examined by numerous studies (Hilderbrand et al., 1998; Roni et al., 2002, 2010, 2014; Carah et al., 2014). However, little is known about the environmental impacts associated with the river restoration process. Extensive literature review suggests that LCA techniques have never been applied to river restoration. Thus, research that quantifies the environmental impacts of the river restoration process will provide valuable information to land managers and restoration practitioners.

Beyond quantifying the environmental impacts of a singular river restoration project, LCA could serve as a repeatable part of a monitoring program. LCA is an internationally standardized process with four distinct phases including Goal and Scope, Life Cycle Inventory (LCI), Life Cycle Impact Assessment (LCIA), and Interpretation. The goal and scope phase defines the context of the study and communicates what is being studied, the study boundaries, limitations, impact categories. The LCI phase involves the data collection and initial quantifications of inputs and outputs of the product system. The LCIA phase assigns the LCI results into impact categories and calculates their magnitude. In the interpretation phase, the LCA practitioner considers the results of the LCIA and often presents the findings in the form of conclusions or recommendations (ISO, 2006). This review offers a background on how LCA techniques have been used in various fields and how the LCA methodology may be adapted to quantify the environmental impacts of a SHI project. The specific objectives are to: (1) review pertinent LCA studies in the fields of forestry, river projects, and construction and materials projects (see appendix, Table A1); (2) identify the appropriate goal and scope, life cycle inventory analysis (LCI), life cycle impact assessment (LCIA), and life cycle interpretation phases as specified in the ISO 14040:2006 document for SHI projects.

\subsection{LCA Applications in Forest Harvest and Management Scenarios}

LCA has been used to quantify the environmental impacts of producing forest products (Dias and Arroja, 2012; González-García et al., 2012, 2013b; a, 2014b; a; Cambria and Pierangeli, 2012; 
Handler et al., 2014; Han et al., 2015). A component of each of these studies models the environmental impacts of using heavy equipment to log, forward, and transport logs. Frequently this aspect of the process is responsible for the largest contribution to environmental impacts or is a "hotspot" within the production system (Dias and Arroja, 2012; González-García et al., 2012, 2013b, 2014b; Cambria and Pierangeli, 2012). Since heavy equipment is frequently used in the river restoration process (Carah et al., 2014), it is important to review LCA studies on forest product systems. This section summarized the goal and scope, LCI, LCIA, and interpretation phases of several LCA studies on forest products.

The goal and scope section of many forestry studies focus on the production of roundwood. Roundwood refers to a log that has been grown, harvested, processed, and delivered to the mill. Forest products studies tend to use a 'cradle-to-gate' methodology, considering environmental impacts associated with: site preparation, stand establishment and tending, final logging, and transportation to the mill 'gate.' Site preparation activities may include land clearing, herbicide treatment, road preparation and fertilizing. Stand establishment and tending activities include seedling establishment, planting, thinning, and preliminary harvesting. The final logging phase includes final cutting, yarding, and loading onto trucks- a process which can be like some river restoration activities. Last, transportation activities include the final hauling of logs to the sawmill gate (Dias and Arroja, 2012; Cambria and Pierangeli, 2012; González-García et al., 2013a, 2014b; a; Han et al., 2015).

Also within the goal and scope phase of a LCA, a functional unit is used to define what is being studied and to define the inputs and outputs of the LCI and LCIA phases (ISO, 2006). For instance, the majority of the forestry studies reviewed use $1 \mathrm{~m}^{3}$ of roundwood either including bark, or under the bark as the functional unit (Dias and Arroja, 2012; Cambria and Pierangeli, 2012; González-García et al., 2014a; Han et al., 2015). Other studies have different functional 
units, such as one green metric tonne of forest biomass (Handler et al., 2014), growing one hectare of willows (González-García et al., 2012), or producing 1 millijoule of heat from the combustion of willow chips (González-García et al., 2013b).

During the LCI phase, these forestry studies received primary information on equipment usage and harvest processes through interviews with forest managers, land managers, and from logger surveys (González-García et al., 2012, 2013a, 2014b; Cambria and Pierangeli, 2012; Handler et al., 2014; Han et al., 2015). One such study associated with redwood production in California utilized surveys from a collection of companies which make up $90 \%$ of the redwood decking industry in Northern California (Han et al., 2015). An analysis of roundwood supply in Michigan used logger survey data mailed to 220 survey respondents to provide an accurate picture of logging across the state. These surveys provided information on harvesting and transportation strategies, ultimately leading to analysis of three equipment configurations: a) cut-to-length full processor/forwarder, (b) feller-buncher/skidder/slasher, (c) chainsaws/skidders. The study went on to examine impacts associated with the each equipment configuration scenario (Handler et al., 2014).

Secondary information is typically compiled from published technical reports and other reputable data sets. A common data set used is the Ecoinvent database (Ecoinvent, 2016), this database contains unit process associated with harvesting equipment and has been used in a variety of timber harvest studies (Dias and Arroja, 2012; González-García et al., 2012, 2013a, 2014a). Other forestry studies incorporate data from previous studies and other published data sets and national publications (Cambria and Pierangeli, 2012; Han et al., 2015).

During the LCIA phase, an impact assessment method is an asset used to specify, assign, and calculate the environmental impacts of a product system. In European forestry studies the CML 2 baseline 2000 V2.04 was a common impact assessment method. An American study used the 
TRACI impact assessment package produced by the Environmental Protection Agency (Han et al. 2015). Regardless of the impact assessment package, many studies considered global warming, eutrophication, acidification, ozone depletion, photochemical ozone formation, human toxicity, and ecotoxicity (Dias and Arroja, 2012; González-García et al., 2012, 2013a, 2014a; Cambria and Pierangeli, 2012).

In life cycle interpretation, many forestry studies documented hotspots during final harvesting. Final harvesting involved using a plethora of heavy equipment including log skidders, adapted farm tractors, and log forwarders to cut and transport logs. These types of harvesting equipment have a large fuel requirement and impart large contributions to global warming potential, acidification, and photochemical ozone formation (Dias and Arroja, 2012; González-García et al., 2014b; a; Han et al., 2015). Beyond identifying key contributors, forestry studies tend to model several scenarios which quantify the impacts of different silvicultural techniques (Dias and Arroja, 2012; González-García et al., 2014b; a; Han et al., 2015). For instance, a study by Han et al., (2015) modeled the impacts from uneven- and even-aged timber management systems in northern California. Han et al., (2015) found that an even-aged management system which used manual-ground based harvesting outperformed its counterparts in both even-aged and unevenaged scenarios. Another study by Dias and Arroja (2012) modeled high intensity forest management with best practices, high intensity forest management with traditional practices, and low intensity forest management in both eucalypt and maritime pine wood production systems in Portugal. Dias and Arroja (2012) found that low-intensity management practices in maritime pine wood production systems generated the least environmental impacts per $\mathrm{m}^{3}$ of wood. Lowintensity management practices in pine wood forested outperformed its eucalypt counterpart because eucalypt forests required greater site preparation and more standing tending, had smaller dimensions, and required greater fertilizer use. Life cycle impacts tended to vary greatly depending on silvicultural technique. Despite this, most studies found that the final harvesting 
was the most impactful phases of production (Dias and Arroja, 2012; González-García et al., 2012, 2013a, 2014a; Cambria and Pierangeli, 2012).

Aside from the final harvest, another hotspot in forest product production was the use of fertilizers. Fertilizers were used to increase plant vigor, which led to greater environmental impacts, particularly in upstream manufacturing. The application of these fertilizers lead to greater emissions to soil and water, increasing the amount eutrophication and acidification potentials of these production systems (Dias and Arroja, 2012; González-García et al., 2012, 2013a, 2014a; Cambria and Pierangeli, 2012). Despite this, many product systems used fertilizer because it increased yield and, in some cases, resulted in a better environmental profile. A study by Gonzalez-Garcia et al. (2012) found that when fertilizers were added to long term commercial willow plantation in Sweden, the operations had a better overall environmental performance when compared to operations that did not use fertilizer. However, Gonzalez-Garcia et al. (2012) noted that when fertilizers were used the eutrophication and acidification potential increased significantly.

Reviewing LCA studies on timber harvest operations suggests that the use of heavy equipment is a common hotspot. These observations are important because the river restoration process which often requires a great deal of heavy machinery and equipment use. River restoration projects may use excavators, dump trucks, front-end loaders, and chainsaws (Scotts et al., 2014) which are used to fall trees, manipulate large materials, and excavate earth materials (Carah et al., 2014). Forest product studies reviewed here suggest that these activities can impart significant environmental impacts. This is especially true if materials are transported across great distances. Han et al. (2015), approximated that the loading and hauling of logs contributed to nearly $37 \%$ of the global warming impacts. The transportation of these large materials may also be a large contributor to the environmental impacts of the river restoration process. The evidence 
substantiates an evaluation of the environmental impacts associated with the use of heavy equipment to construct and transport large materials in the river restoration processes.

\subsection{LCA Applications in Hydropower and Dam Building}

LCA has been used to quantify the environmental impacts from hydropower and dam building projects. These projects focus on quantifying the environmental impacts from small- and largescale hydropower dams and small-scale check dams. These river installations typically involve the use of heavy equipment, which is used to construct the facilities that generate electricity or modify flow regimes. While river restoration in California does not seek to generate electricity, there are similarities between the processes, especially during the construction of small-scale dams (Suwanit and Gheewala, 2011; Varun et al., 2012; Liu et al., 2013; Kayo et al., 2014; Zhang et al., 2015).

In the goal and scope phase, studies that examine hydropower installations typically compare the performance of two or more hydropower dam designs. A study by Zhang et al. (2015) compared the environmental performances of two large-scale dam designs. Other studies examined multiple designs of small-scale hydropower dam designs and timber check dams (Kayo et al. 2014; Suwanit and Gheewala 2011; Varun et al. 2012). Functional units vary by study hydropower dams is one unit of electricity produced, either in kilowatt-hours (Zhang et al., 2015) or in miliwatt-hours (Suwanit and Gheewala 2011; Varun et al. 2012).Another study by Liu et al., (2013) compared concrete and rockfill dams based on a single unit of concrete, while another study used life cycle techniques to assess the carbon balance of a timber check dam (Kayo et al. 2014). Hydropower studies set system boundaries around material production, construction activities, transportation, and operation and maintenance (Suwanit and Gheewala, 2011; Varun et al., 2012; Liu et al., 2013; Zhang et al., 2015). 
During LCI, Primary data is typically gathered from members of the industry. In a study that examined mini-hydropower plants in India, primary data was gathered on site, while secondary data were gathered from the literature and Ecoinvent databases (Suwanit and Gheewala 2011). In a study by Liu et al., (2013) data were gathered by the government hydropower research institutes. Other studies employed similar LCI techniques (Kayo et al. 2014; Varun et al. 2012; Zhang et al. 2015).

During the LCIA phase, most of these studies focused on the greenhouse gas emissions, particularly with $\mathrm{CO}_{2}$ emissions (Suwanit and Gheewala, 2011; Varun et al., 2012; Liu et al., 2013; Zhang et al., 2015). One study used the CML 2001 baseline impact assessment methodology which quantified the impacts in abiotic depletion, acidification, global warming, freshwater aquatic ecotoxicity, human toxicity, photochemical oxidation, and fossil fuel resource depletion (Suwanit and Gheewala, 2011). Liu et al., (2013) considered NOx emissions, CO emissions, and particulate matter emissions.

In the life cycle interpretation phase, most of these studies identified an installation design which was less impactful. Two studies compared the environmental impacts of rockfill and concrete hydropower dams, both studies found suggest earth-core dams were less impactful than their concrete counterparts. This was largely due to the upstream impacts associated with producing concrete and the fact that concrete dams tended to use more concrete (Liu et al., 2013; Zhang et al., 2015). For instance, in Zhang et al. (2015) the difference was largely attributed to the material production stage, where the concrete-gravity dam emitted $46 \%$ more $\mathrm{kg} \mathrm{CO}_{2}$ eq. than the earthrockfill dam.

In smaller scale dam building, a study by Suwanit and Gheewala (2011) found that construction and transportation are the most impactful phases in the life cycle of mini-hydropower plants in Thailand. This was largely due to the huge amount of materials, shipping costs to Thailand, and 
the remoteness of the mini-hydropower plants. Varun et al. (2012) examined different engineering designs of small hydropower schemes in India and found that the $\mathrm{CO}_{2}$ emissions depended on the head design and capacity of each project.

In a unique study by Kayo et al. (2014), the carbon footprint of simple timber check dam was compared to the carbon footprint of a simple concrete check dam. This study had broad system boundaries, which incorporated resource extraction, resource transport, manufacturing, construction, maintenance, and disposal. This study found that the timber check dam performed better than the concrete check dam after an operation period of 22 years, especially if reforestation occurred after the timber was harvested and used in construction. The use of forestresidue and sawmill-residue as a fuel source also reduced the carbon footprint of timber check dams.

The results from these studies suggest that the more highly engineered structures tended to have greater environmental impacts. This was largely due to the upstream impacts of material production (Liu et al., 2013; Zhang et al., 2015) and in some cases the shipping distances of materials (Suwanit and Gheewala, 2011). River restoration deals with similar challenges, often materials are engineered (steel cabling, epoxy, rebar, concrete) or transported to remote locations. It is likely that these aspects of the river restoration process will also generate significant contributions to the environmental impacts.

\subsection{LCA Applications in Construction and Materials Production}

This section reviews a mixed-bag of LCA studies on road development, aggregate production and the production of erosion control materials. River restoration requires similar processes to some construction projects. For example, construction contracting groups are often hired to build structures and operate similar types of equipment in both processes (Cook, 2016). The river restoration process is like materials production systems because both systems may use similar 
types of earthmovers (Stripple, 2001; Barandica et al., 2013; Cook, 2016). This section also highlights a study on erosion control materials because conducting erosion control is commonly practiced in river restoration.

The goal and scope of construction and materials production varies depending on the product system. For instance, many LCA studies on road building address the environmental impacts from creating $1 \mathrm{~km}$ of road, with a system boundary that includes materials production, site preparation, construction, operation, maintenance, and disposal (Stripple, 2001; Barandica et al., 2013). Studies on aggregate production or use designate a given amount of aggregate as a functional unit. For instance, Gan et al., (2016) used $1 \mathrm{~kg}$ of aggregate as a functional unit and a system boundary which included materials extraction, processing, transport, and disposal (López Gayarre et al., 2015; Gan et al., 2016). One study examined different erosion control methods, including bio-mats, geo-nets, geo-cells and deep-rooted plants. The functional unit for this study was the erosion materials required to cover one hectare of slope. The system boundaries for this study included the production and transportation of raw materials, installation, and hydro-seeding required to install erosion control (Rocco et al. 2015).

In the LCI phase, construction and materials production projects tend to gather primary data from industry sources and secondary data from published datasets (Stripple, 2001). Another road project used a program called CO2struct to model some construction processes (Barandica et al., 2013). Aggregate studies receive primary data from supplier surveys and tend to report their data in tables that highlight gasoline and diesel consumption (Gan et al. 2016; Gayarre et al. 2015). In Rocco et al. (2015), data was presented on each of the four-erosion control method usage patterns from industry sources, while secondary data was gathered from European Union published datasets. 
During the LCIA phase, the global warming potential $\left(\mathrm{kg} \mathrm{CO}^{2}\right.$ eq.) was quantified in every construction and materials production study examined in this review (Stripple, 2001; Barandica et al., 2013; López Gayarre et al., 2015; Rocco et al., 2015; Gan et al., 2016a). Other commonly examined impact categories were acidification and eutrophication. Rocco et al. (2016) used the impact assessment categories associated with an exergy analysis, including Cumulative Exergy Demand, the Thermo-Ecological Cost, and the Cumulative Exergy Extraction from Natural Environment. Together these methodologies measured impacts associated with non-renewable fossil fuels, non-renewable nuclear energy, renewable kinetic energy, renewable solar energy, renewable potential energy, non-renewable primary energy, renewable biomass energy, renewable water resources, non-renewable metals, non-renewable minerals, and land use.

In the life cycle interpretation phase, finding varied by study topic. Gayarre et al., (2015) compared natural aggregate, recycled aggregate at a fixed plant, and recycled aggregate at a mobile plant for concrete kerbs and found that natural aggregate was a less impactful than its recycled counterparts. This difference was associated with a with the operation of a rock crusher and processing unit in recycled aggregate. Transportation was also a hotspot, and the use of local products was encouraged (Gan et al. 2015). Rocco et al. (2016) found that deep rooted plants were a much better option when compared to three more highly engineered geo-textile fabrics produced for erosion control.

As in many other studies in this review, machinery and materials transportation were consistent hotspots. Of particular importance to river restoration managers were the findings on deep-rooted plants in Rocco et al. (2016). Deep-rooted plants performed better when compared to geo-textile fabrics. Geo-textiles have been used for erosion control in variety of different settings, including river restoration (Rocco et al. 2016). Assuming this study would have similar results in the western United States, deep rooted plants could be a more environmentally sensitive option than 
any other method of erosion control, even straw mulch, which is also commonly used (Flosi et al., 2010).

\subsection{Applying ISO Framework to River Restoration}

The goal of this section is to apply the ISO 14040 (2006) LCA Principles and Framework to river restoration projects, in particularly to stream habitat improvement (SHI). Applying the ISO framework to a SHI project will provide managers with the tools to evaluate their own SHI projects, or on a broader scale, to all river restoration projects. To justify the appropriate goal and scope, life cycle inventory analysis (LCI), life cycle impact assessment (LCIA), and life cycle interpretation phases, this section uses examples from the literature and adapts methods used from several key studies.

In the goal and scope phase, this study proposes using a cradle-to-gate analysis to quantify the environmental impacts from conducting SHI. A cradle-to-gate analysis was employed in various other related studies. For instance, Han et al. (2015) used a cradle-to-gate analysis to address impacts associated with various management scenarios in northern California redwood forests. A cradle-to-gate analysis is commonly used in other forest management studies (Saud et al., 2013; González-García et al., 2013a, 2014b), and in various studies in different fields (Suwanit and Gheewala, 2011; McGrath et al., 2015; Gan et al., 2016b). Using a cradle-to-gate methodology would allow mangers to quickly evaluate projects upon their construction and omit lengthy instream and decommission phases and to quantify the impacts from the most intensive processes. Furthermore, little or no action is taken once restoration structures are placed, especially in SHI projects (Dietterick, Robins, verbal communication 2016). The primary processes include raw material production, transportation to the site, and on-site construction activities (Figure 1). 


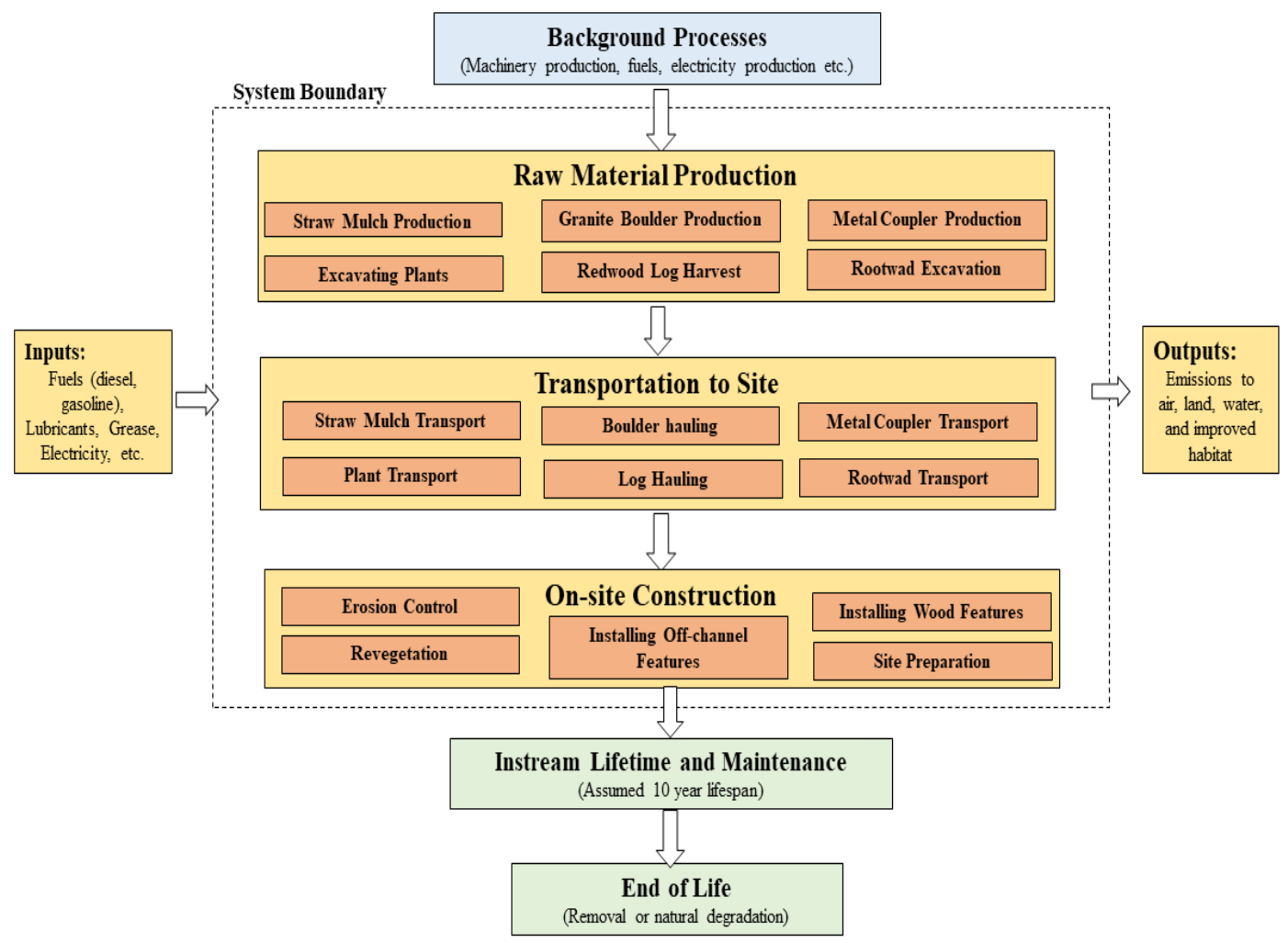

Figure 1. Product system diagram for the stream habitat improvement (SHI) process with the proposed cradle-to-gate system boundaries.

The raw material production phase examines the impacts associated with the collection or production of the raw materials used to conduct SHI. Raw materials may include logs, boulders, metal pieces, and other engineered materials which require some element of manufacturing (Kail et al. 2007). Studies have demonstrated that timber harvest activities and aggregate extraction have substantial environmental impacts (Dias and Arroja, 2012; Gan et al. 2016; Gayarre et al. 2015; Gonazalez-Garcia et al. 2014 Han et al. 2015).

Once these materials are harvested, mined, or produced they must be transported from the source gate to the appropriate river reach. The transportation to the site phase addresses the impacts associated with delivering raw materials and heavy equipment to the site. Some studies document substantial impacts associated with the transportation of raw materials (Gan et al. 2015; Han et al. 2015; Suwanit and Gheewala 2011), which is especially important considering the remoteness of some restorable rivers. 
Once the materials are on-site, a certain degree of construction and manipulation must occur. The on-site construction phase addresses the impacts from site preparation, installing wood features, off-channel features, erosion control, and revegetation. These on-site activities often require the use of chainsaws and heavy equipment (Carah et al. 2014), heavy equipment operation was a frequently observed hotspot in the LCA studies (Barandica et al. 2013; Dias and Arroja, 2012; Gan et al. 2016; Gayarre et al. 2015; Stripple, 2001; Suwanit and Gheewala 2011, Zhang et al. 2015). Thus, impacts associated with heavy equipment operation are important to quantify and evaluate.

To quantify the impacts of SHI projects, this study used one meter of stream restored as a reference unit. Units of length have been used as functional units in LCA studies on roads (Stripple, 2001; Barandica et al., 2013), but units of length do not represent the true function of SHI projects. The goal of many SHI projects in California is to increase the abundance of endangered or threatened salmonids (Gallagher, 2012). The changes in fish abundance from SHI projects would be an ideal functional unit for LCA studies. However, these data may not be readily available, one study suggests that at least five years of pre- and post-installation data may be required to assess changes in fish populations (Koljonen et al., 2013). As an alternative functional unit, studies have demonstrated that stream instream structures can increase habitat complexity (Gallagher, 2012; Howson et al., 2012). A measurement of habitat complexity would provide a relatively quick approximation of one of key ecosystem functions SHI provides. In lieu of having fish abundance data this study proposes using available topographic survey data to establish a functional unit.

The LCI phase included collecting and checking all the primary data associated with each of the phases in the process flow (Figure 1). Special attention was paid to heavy equipment use because it was a frequently documented hotspot in many similar production system (Cambria and Pierangeli 2012; Dias and Arroja 2012; Gonzalez-Garcia et al. 2014; Gonzalez-Garcia et al. 
2014 ${ }_{2}$; Gonzalez-Garcia et al. 2013; Gonzalez-Garcia 2012; Han et al. 2015). Additionally, the weights of materials and haul distances were recorded to quantify the impacts associated with transportation and raw material production (Suwanit and Gheewala, 2011). For secondary data, this study used published data sets from Ecoinvent. Ecoinvent was the most commonly used secondary data set in the studied reviewed here (González-García et al., 2013a, 2014a; McGrath et al., 2015; Rocco et al., 2015; Gan et al., 2016).

During the LCIA phase, common impact categories were global warming potential, eutrophication, photochemical ozone formation, and acidification. To compare results from the widest range of LCA studies, a practitioner may focus on the aforementioned impact categories. This study proposes using the TRACI 2.1 impact methodology, which quantifies impacts associated with the four most commonly evaluated categories. TRACI 2.1 was created by the U.S. Environmental Protection Agency and was used in several key LCA studies in the U.S. Using TRACI will simplify the life cycle interpretation phase because allows for comparison with other similar studies.

For the life cycle interpretation phase, special attention was paid to the operation of diesel-fired equipment. Especially, considering that diesel consumption in heavy equipment was a hotspot in similar production systems (Barandica et al. 2013; Dias and Arroja, 2012; Gan et al. 2016; Gayarre et al. 2015; Stripple, 2001; Suwanit and Gheewala 2011, Zhang et al. 2015). Beyond diesel fired-machinery, this literature review suggests that other hotspots may be present. For instance, the use of fertilizer, upstream raw material production processes, and various logging activities were also common hotspots. Many restoration activities use products such as straw mulch, timber, and plant materials all of which may require fertilizer. Studies demonstrated that the use of fertilizer increase impacts in various product systems (González-García et al., 2012, 2013b; Cambria and Pierangeli, 2012). Also, the raw material extraction phase in SHI may be 
very impactful. For instance, supply of aggregate has substantial impacts, particularly in upstream production processes (Gan et al. 2016; Gayarre et al. 2015). Similarly, the supply of timber logs has also shown to have substantial impacts as well (Han et al. 2015; Handle et al. 2014). SHI projects use a variety of materials to improve habitat, which include processed logs and quarried rock. The impacts associated with producing some these materials has been documented in prior studies, however, the specific approach used in river restoration has never been examined using these LCA techniques.

This study will demonstrate the broad applicability of LCA and give valuable information to LCA practitioners and river managers. LCA studies have shown that similar production systems produce considerable impacts. Heavy equipment operation was a frequent hotspot in many similar production systems, this study hypothesizes that this will be the case in SHI projects as well. This research will aim to apply life cycle thinking to quantify the environmental impacts, identify key contributors, and on a larger scope address the negative environmental repercussions of conducting an environmental restoration project. 


\section{Methods}

\subsection{Quantifying Environmental Performance}

This chapter describes the Lower Scotts Creek Floodplain and Habitat Enhancement Project (LSCR) in the study site section, and how LCA was used to quantify the environmental impacts associated with SHI. Additionally, this section describes how LCA and topographic effectiveness monitoring were incorporated to quantify the environmental performance of the LSCR. The study site is described and includes a general site description and a brief description of the hydrologic conditions. The LCA methodology section describes how this study quantified the baseline results, identified the key contributor to impacts, and conducted the scenario analysis. LCA methodology is centered on the LCA ISO 14040 framework (ISO, 2006) including goal and scope, life cycle inventory (LCI), life cycle impact assessment (LCIA), and interpretation. The effectiveness monitoring section describes how: total station surveys were conducted, digital elevation models (DEMs) were created, Topographic Diversity Index (TDI) percent change was calculated, and environmental performance was calculated (Figure 2). 


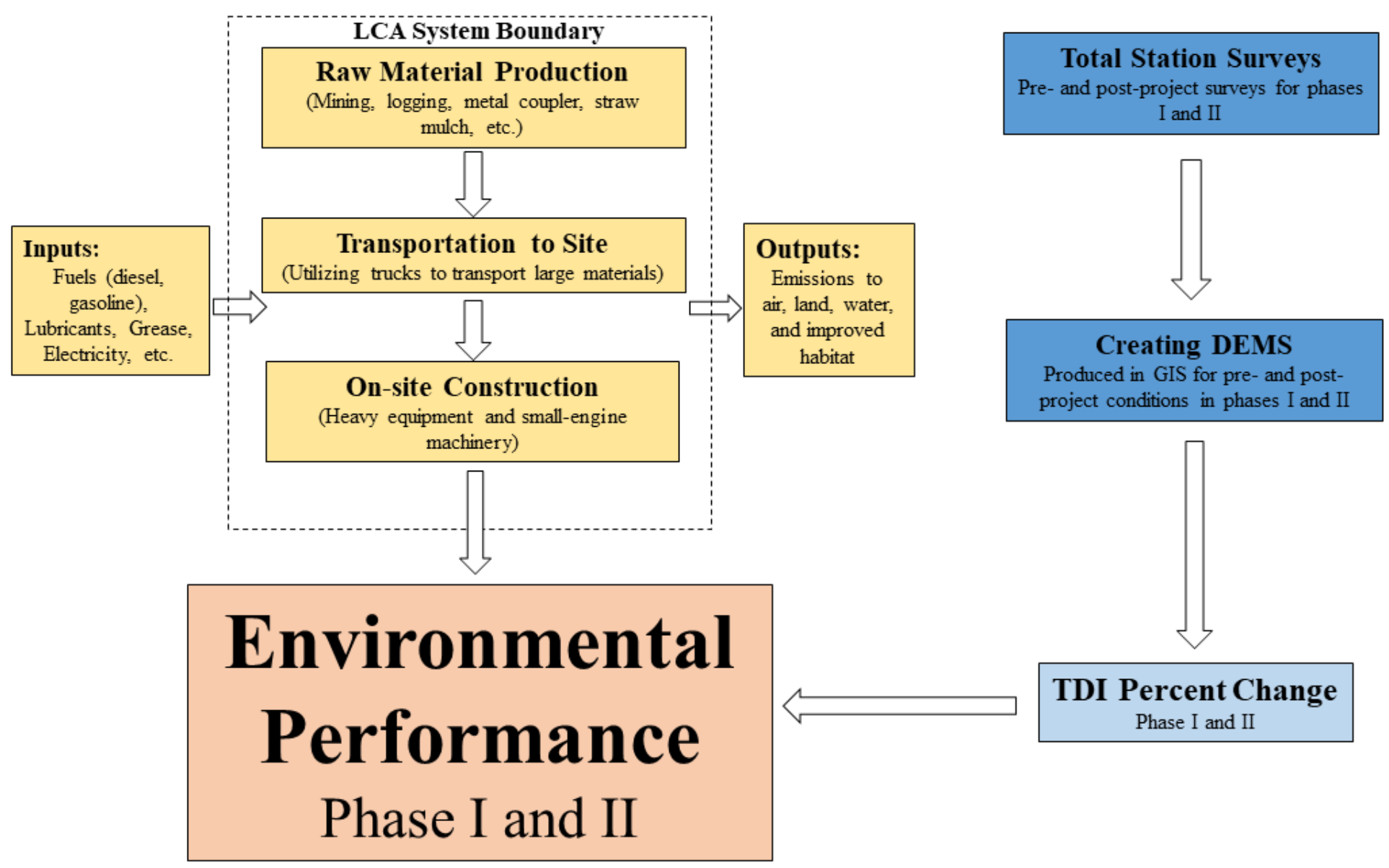

Figure 2. A schematic diagram of the LCA methodology used to quantify the environmental performance of SHI projects. 


\subsection{Study Site}

The Lower Scotts Creek Floodplain and Habitat Enhancement Project (LSCR) was installed along the lower reaches of Scotts Creek, located on the Central Coast of California along the north Coast of Santa Cruz County (Figure 3). The Scotts Creek watershed is approximately 78 $\mathrm{km}^{2}$ and is a $5^{\text {th }}$ order stream network (based on LiDAR-derived drainage data). The stream originates between 500 meters and 600 meters in elevation and drains to the ocean approximately 19 kilometers north of the city of Santa Cruz (Hillard, 2015). Scotts Creek maintains the only persistent population of Central California Coast (CCC) Coho Salmon (Oncorhynchus kisutch) in the Santa Cruz Mountains Diversity Stratum. CCC Coho salmon populations within Scotts Creek have been very low (Figure 4). The degradation of habitat has been the primary cause for the decline of both CCC Coho and CCC steelhead (NMFS, 2012). Habitat loss in lower Scotts Creek was associated with a legacy of dredging, channelization, wood removal, clearing of riparian forest, and the construction of levees. The goals of the LSCR were to restore floodplain connectivity and improve salmonid habitat conditions by removing short sections of the levee, and by creating alcove habitat, off-channel pool connections, tributary connections, and LWCs.

This case study compared two reaches within the LSCR, phase I and II measure approximately 160 meters and 125 meters respectively. A topographic survey was conducted for phase I in summer 2014 (pre-project) and in summer 2015 (post-project) and for phase II in summer 2015 (pre-project) and in summer 2016 (post-project). Phase II is situated immediately upstream of phase I. Within each study reach four LWCs were installed, each LWC was composed of a redwood log, boulder ballast, rootwad, and in-situ red alder (Alnus rubra). Industrial strength metal couplers were used to create flexible connections between rootwads, boulders, redwood logs, and in some cases to fasten logs against brace trees. The goals of each LWC was to increase instream complexity, initiate channel scour, increase instream refugia habitat, and/or redirect flow into off-channel features. In the phase I, a failing levee was excavated in four locations to 
increase floodplain connectivity and opportunity for refuge habitat during periods of high-flow.

In the phase II, an alcove was excavated at one location for refuge habitat (Cook, 2016). The design of the project is similar in both phases, the major difference being the amount of material excavated in off-channel features. Phase I and II removed approximately 279 and 92 cubic meters or material, respectively.

The substrate size, wetted width, and depths were estimated from data collected in the field in summer 2016. The flow rates were measured at a gauging site approximately 800 meters upstream of the study reaches. During the study period for phase I, there was only one high-flow event ( $<1000 \mathrm{cfs})$. During the study period of phase II there were two high-flow events (measuring $<1000 \mathrm{cfs}$ ) and two more minor flow events were recorded as well (measuring $\approx 700$ and $900 \mathrm{cfs})$.

The channel substrate is made of similar alluvial substrate, dominant substrate in both reaches is mudstone, with a minor component of granitic rocks from higher in the watershed. The percent substrate and channel dimensions are also similar between both study reaches, phase II is slightly wider, deeper, and has predominantly gravel substrate, silt/clay substrate. Whereas, phase I is slightly narrower, shallow and has predominately gravel and sand substrate (Table 1).

Table 1. Selected stream measurements for Phase I and II of the LSCR.

\begin{tabular}{lcc} 
Measurement & Phase I & Phase II \\
\hline Legth $(\mathrm{m})$ & 160 & 125 \\
Average Wetted Width $(\mathrm{m})$ & 6.15 & 7.15 \\
Average Depth $(\mathrm{m})$ & 0.35 & 0.42 \\
\% Silt/Clay & 16 & 23 \\
\% Sand $(<0.2 \mathrm{~cm})$ & 23 & 14 \\
\% Gravel $(0.2-6.4 \mathrm{~cm})$ & 23 & 28 \\
\% Small Cobble $(6.4-12.7 \mathrm{~cm})$ & 16 & 13 \\
\% Large Cobble $(12.7-25.4 \mathrm{~cm})$ & 16 & 15 \\
\% Boulder $(>25.4 \mathrm{~cm})$ & 6 & 6 \\
\% Bedrock & 0 & 0
\end{tabular}




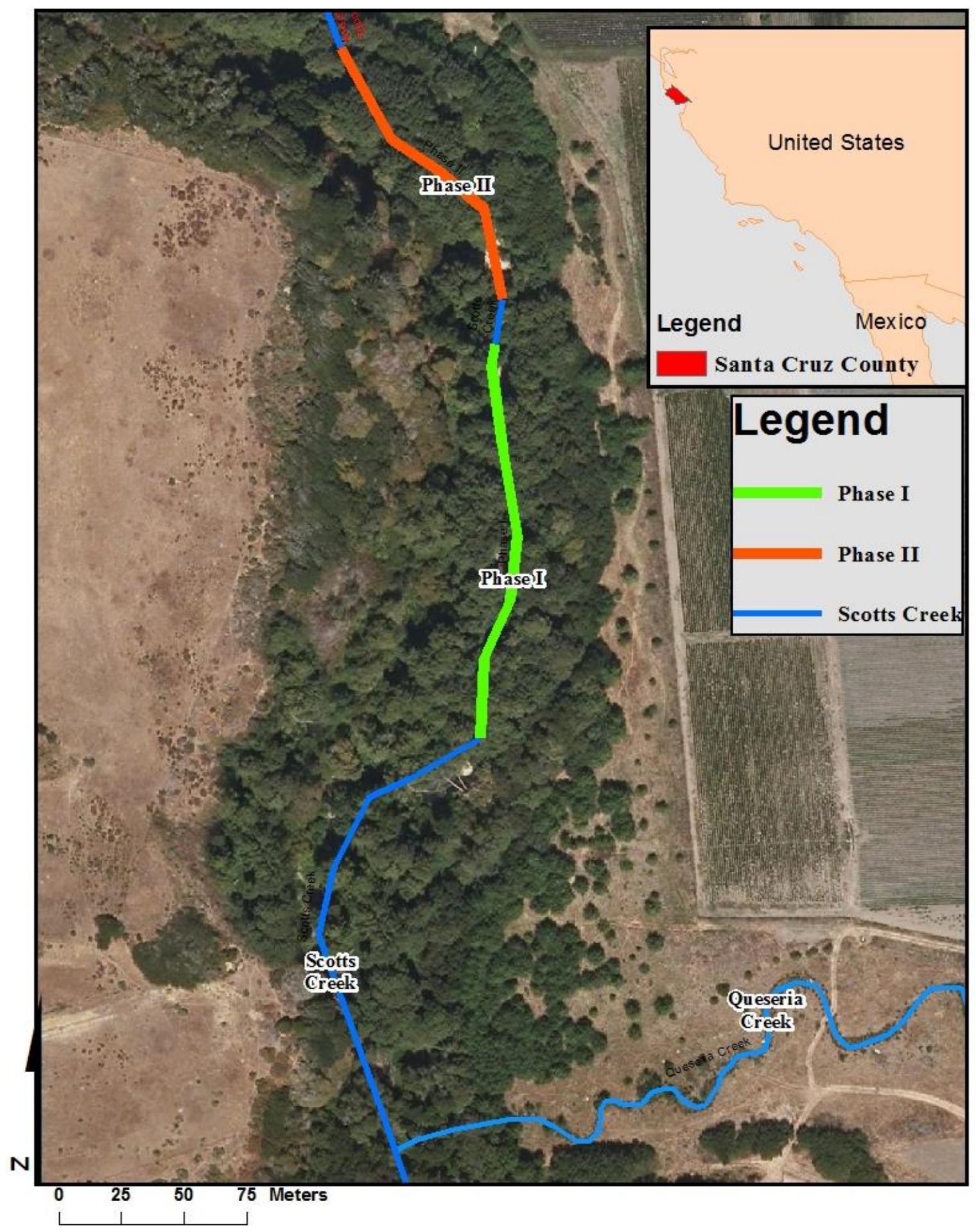

Figure 3. Location of Scott's Creek and phase I and II of the Lower Scotts Creek Floodplain and Habitat Enhancement. 


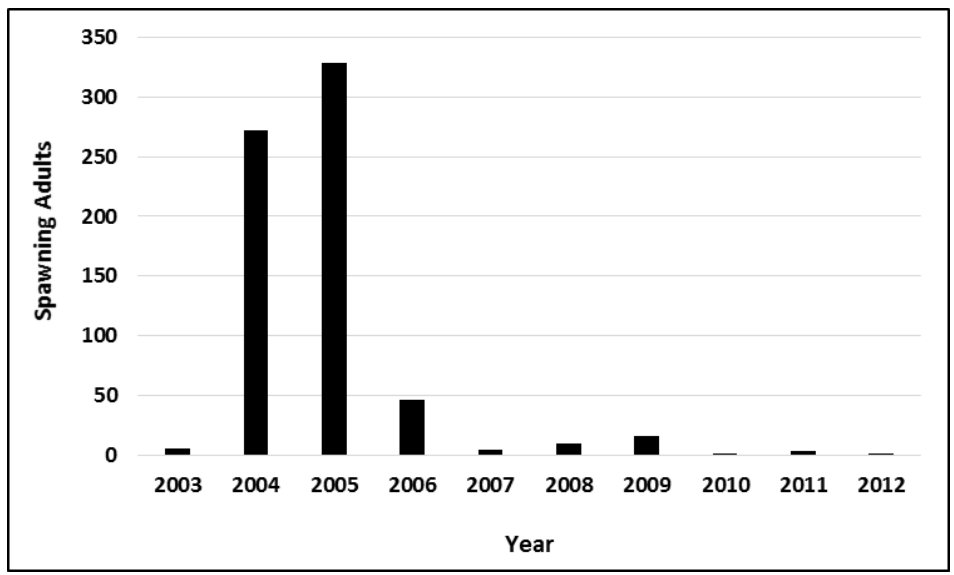

Figure 4 CCC Coho Salmon spawning adult estimates for Scotts creek (excerpted from NMFS, 2012).

\subsection{LCA Study Methodology}

\subsubsection{LCA Goal and Scope}

The goal of this LCA study is to quantify the baseline environmental impacts of phase I and II of the LSCR. The reasons for carrying out this study is to inform managers on the potential environmental impacts of the river restoration process. The intended audience for this study will be river restoration managers, LCA practitioners, land managers, fisheries experts, hydrologists, and geomorphologists. The results of this study are to be used in comparative assertions and are intended to be disclosed to the public.

This study used a limited scope cradle-to-gate analysis which adapted an abbreviated form of the internationally accepted standards (ISO, 2006) to quantify the environmental impacts from the SHI process. The function of this system is to improve instream habitat for various fish species, specifically CCC Coho salmon. The systems boundaries were limited to the unit processes associated with raw material production, material transportation, and on-site construction associated with the SHI process. The reference unit of study was one meter of stream restored, this reference unit was later used to scale the impacts to reflect a one percent TDI increase (Figure 2). Using one percent TDI increase as the functional unit allowed the author to compare 
the functionality of phases I and II. All of the inputs and outputs in this study were allocated to the SHI process. This study used primary data which was gathered in field during SHI construction process and with interviews from the LSCR project manager. OpenLCA v1.7.0 (Greendelta, 2018) LCA modeling software was used along with Ecoinvent (Ecoinvent, 2016) secondary data to quantify the environmental impacts from the SHI process.

\subsubsection{Assumption and Limitations}

This study was designed to inform river managers, LCA practitioners, and other land management agencies on the environmental impacts of SHI. Furthermore, the techniques used here are designed to be reproduced by river managers, who may not be familiar with LCA techniques. Due to this, data and other technicalities were kept to a minimum, to cater to those interested parties who may not be familiar with LCA.

This was a limited scope LCA study, which modeled the cradle-to-gate impacts of the SHI process. The emissions associated with instream life and end-of-life are not considered and are assumed to minimal (Dietterick, Robins, personal comm. 2017). The installations in this project were assumed to have a lifespan of ten years. Ten years was chosen as a conservative option (similar structures are designed to stay in place 25 years (Cederholm et al., 1997)) and was based off the 10-year flood recurrence interval for which the instream structures were rated to be able to withstand.

The unit processes included all upstream impacts, including infrastructure maintenance, raw material acquisition, machinery maintenance, and manufacturing. SHI activities were represented using global unit processes from Ecoinvent (Wernet, 2016). Global unit processes were used because there was a lack of data specific to North American systems. Many of the Ecoinvent unit processes were specific to European systems, thus making global unit processes the best option. Additionally, a few specific unit processes were not available in the Ecoinvent databases and 
were substituted for similar processes. For instance, the quarrying of granite boulders was not available. The author chose to represent this process with a gravel production process which incorporated mining and other similar processes. Similarly, the logging activities were represented using global low-intensity secondary forest management processes. This unit process was chosen because it was the closest approximation redwood forest management that is practiced in this region of California, USA.

The life cycle impacts were the focus of this study, data on associated ecological disturbances were not collected. For example, this study did not account for the impacts associated with tree removal or the physical impacts from equipment usage. Many of these impacts were mitigated, for instance, each tree which was removed during on-site construction was replaced with three tree seedlings. This study did not account for the impacts associated with transporting crews to the job site. For critical review this study was critiqued by three thesis committee members and was presented in the form of a thesis document. The committee members included an expert in LCA, hydrology, and restoration ecology.

\subsubsection{Life Cycle Inventory (LCI)}

The raw material production phase modeled the impacts associated with producing metal couplers, quarrying boulder ballasts, harvesting redwood logs, growing straw mulch for erosion control, excavating rootwads, and harvesting plant materials. The materials used in production and setting of the metal couplers were modeled using a steel production process, a zinc-coating process (galvanizing), and an epoxy production process (epoxy was used to set couplers in rocks). The weight and size of the metal couplers were estimated from field notes. The acquisition of boulder ballasts was modeled using a gravel production process, the weights of the boulders where estimated in the field with input from the project manager and equipment operators. The harvesting of redwood logs was modeled using a global roundwood production process, the 
volume of the logs was estimated using the scribner method. The excavating of rootwads was modeled using a machine operation process. The amount of time on the excavator was estimated from field notes. Similarly, A mid-sized backhoe was used to excavate plant materials, the amount of time on the backhoe was estimated with input from landowners. The production of straw mulch was modeled using a straw production process, whose weight was estimated from field notes. The production of machinery was included in equipment operation unit processes. The key inputs to the raw material production phase were the weights of the materials, the amount of time operating equipment, and the equipment horsepower (Table 2).

Table 2. LCI inputs and technical notes for raw material production phase of the LSCR. Phase I

\begin{tabular}{|c|c|c|c|}
\hline Item & Input & Unit & Activity \\
\hline Granite Boulder & 32000 & lbs. & Four boulders quarried \\
\hline Steel Metal Coupler & 8 & $\mathrm{~kg}$ & Creating industrial metal fasteners \\
\hline Zinc coating & 250 & $i^{2}$ & Galvanizing metal pieces \\
\hline Epoxy resin, liquid & 0.25 & $\mathrm{~kg}$ & Used to set metal couplers \\
\hline Excavating Plants & 16 & hrs & Running a Case 580 super L, Backhoe Production \\
\hline $\begin{array}{l}\text { Redwood Log Harvest } \\
\text { Rootwad Excavation } \\
\text { Straw Mulch Production }\end{array}$ & $\begin{array}{c}7.8 \\
2 \\
1080\end{array}$ & $\begin{array}{l}\mathrm{m}^{3} \\
\text { hrs } \\
\text { lbs. }\end{array}$ & $\begin{array}{l}\text { Logging four redwood trees } \\
\text { Four redwood rootwads excavated from jobsite } \\
24 \text { bales of straw mulch for erosion control }\end{array}$ \\
\hline \multicolumn{4}{|c|}{ Phase II } \\
\hline Item & Input & Unit & Activity \\
\hline Granite Boulder & 40000 & lbs. & Four boulders quarried \\
\hline Steel Metal Coupler & 8 & $\mathrm{~kg}$ & Creating industrial metal fasteners \\
\hline Zinc coating & 250 & in $^{2}$ & Galvanizing metal pieces \\
\hline Epoxy resin, liquid & 0.25 & $\mathrm{~kg}$ & Used to set metal couplers \\
\hline Excavating Plants & 8 & hrs & Running a Case 580 super L, Backhoe Production \\
\hline Redwood Log Harvest & 7.8 & $\mathrm{~m}^{3}$ & Logging four redwood trees \\
\hline Rootwad Excavation & 2 & hrs & Four redwood rootwads excavated from jobsite \\
\hline Straw Mulch Production & 540 & lbs. & 12 bales of straw mulch for erosion control \\
\hline
\end{tabular}

The transportation to site phase of this LCA modeled the impacts associated with the trucking of raw materials and heavy equipment from the source-gate to the job site. The weights of boulder ballasts and rootwads were estimated in the field and with input from the project manager and 
equipment operators. The weight of the redwood logs was estimated by scaling several of the logs in the LSCR and using the Scribner method. The haul distances were estimated from field notes, input from the project managers and contracting groups. Rootwads, boulders, redwood logs, and heavy equipment required large haul trucks to deliver materials. Additionally, heavy equipment transportation was considered as a key transportation process. Data in this phase was entered separately for phases I and II. The key inputs to this group was the weight of material, the type of vehicle used to deliver the material, and the transportation distance (Table 3). Additionally, the backhaul distances were modeled. This study assumed that haul trucks would return to their original departure point. Haul trucks were assumed to be empty unless they were hauling pieces of heavy equipment. Furthermore, the infrastructure maintenance, machinery manufacturing and associated upstream processes were included within the transportation unit processes.

Table 3. LCI inputs and technical notes for the transportation phase of the LSCR.

\begin{tabular}{|c|c|c|c|}
\hline \multicolumn{4}{|c|}{ Phase I } \\
\hline Item & Input & Unit & Activity \\
\hline Hyundai 140 LCD-7 & $30820.6 * 48$ & lbs.*mi & Hauling mid-sized excavator to the site \\
\hline Cat $305.5 \mathrm{E}$ & $11618 * 48$ & lbs.*mi & Hauling compact excavator to the site \\
\hline Bobcat Front Loader 259D & $8945 * 48$ & lbs. *mi & Hauling compact skid-steer to the site \\
\hline Bobtail dump truck & $1 * 48$ & $\mathrm{p}^{*} \mathrm{mi}$ & Driving bobtail dump truck to the site \\
\hline Redwood Logs & $33200 * 33$ & lbs*mi & Hauling redwood logs 33 mile at 8300 lbs. each \\
\hline Boulder Ballasts & $32000 * 40$ & lbs*mi & Hauling boulder ballasts 40 miles at 8000 lbs. each \\
\hline Rootwad Haul & $8000 * 19$ & lbs*mi & Hauling rootwads 19 miles at 2000 lbs. each \\
\hline Metal Coupler Pickup & $1 * 14.1$ & $\mathrm{p}^{*} \mathrm{mi}$ & Picking up metal couplers- 14 mile haul \\
\hline \multicolumn{4}{|c|}{ Phase II } \\
\hline Item & Input & Unit & Activity \\
\hline John Deere 135D & $30736.8 * 65$ & lbs.*mi & Hauling mid-sized excavator to the site \\
\hline Takeuichi TB175 & $17230 * 7.7$ & lbs.*mi & Hauling compact excavator to the site \\
\hline Bobtail dump truck & $1 * 52$ & $\mathrm{p}^{*} \mathrm{mi}$ & Driving bobtail dump truck to the site \\
\hline Redwood Logs & $33200 * 33$ & lbs*mi & Hauling redwood logs 33 mile at 8300 lbs. each \\
\hline Boulder Ballasts & $32000 * 114$ & lbs*mi & Hauling boulder ballasts 40 miles at 8000 lbs. each \\
\hline Rootwad Haul & $8000 * 19$ & lbs*mi & Hauling rootwads 19 miles at 2000 lbs. each \\
\hline Metal Coupler Pickup & $1 * 14.1$ & p*mi & Picking up metal couplers- 14 mile haul \\
\hline
\end{tabular}


The on-site construction phase of this LCA modeled the impacts associated with installation of the LSCR. This study broke the construction phase into five elements including, site preparation, installing off-channel features, installing wood features, conducting erosion control, and revegetating disturbed areas. A variety of equipment was used to conduct these five restoration elements. Erosion control and revegetation primarily used hand tools and small trucks to move people and materials around the site. Site preparation primarily used small-engine equipment to create access corridors for heavy equipment along riparian areas. Installing off-channel features and wood features required the use of a variety of heavy equipment including excavators, skid steers, and dump trucks. The key inputs to this group was the type of equipment, equipment horsepower, material weights, travel distances, and the number of hours spent operating each piece (Table 4 and 5). The upstream production of machinery was included in equipment operation unit processes.

\section{Table 4. LCI inputs and technical notes for on-site construction phase I of the LSCR}

Phase I

\begin{tabular}{cccccc} 
Equipment Make & Equipment Type & Fuel type & Amount & Units & $\begin{array}{c}\text { Engine } \\
\text { Power }\end{array}$ \\
\hline Bobcat Front Loader 259D & Tracked front loader & Diesel & 10 & hrs & $55 \mathrm{~kW}$ \\
Case 580 Super L & Backhoe & Diesel & 16 & $\mathrm{hrs}$ & $67 \mathrm{~kW}$ \\
Cat 305.5E & Compact Excavator & Diesel & 15 & $\mathrm{hrs}$ & $31 \mathrm{~kW}$ \\
Caterpillar 515 & Log Skidder & Diesel & 1.1 & $\mathrm{hrs}$ & $118 \mathrm{~kW}$ \\
Chevrolet 500 & Flatbed Truck & Gasoline & $1 * 27$ & $\mathrm{p}$ *mi & - \\
Honda eu 2000i & Generator & Diesel & 8 & $\mathrm{hrs}$ & - \\
Hyundai 140 LCD-7 & Excavator & Diesel & 48.5 & $\mathrm{hrs}$ & $85.8 \mathrm{~kW}$ \\
John Deere 1023E & Compact Tractor & Diesel & 20 & $\mathrm{hrs}$ & $16.5 \mathrm{~kW}$ \\
Stihl KM 94 R & Hedge Trimmer & Gasoline & 12 & $\mathrm{hrs}$ & - \\
Stihl 261 & Chainsaw & Gasoline & 20 & $\mathrm{hrs}$ & - \\
Stihl HT 250 & Pole Saw & Gasoline & 12 & $\mathrm{hrs}$ & - \\
Bobtail Truck & Single Unit Truck & Diesel & $10000 * 58$ & $\mathrm{lbs} * \mathrm{mi}$ & -
\end{tabular}


Table 5. LCI inputs and technical notes for on-site construction phase II of the LSCR

Phase II

\begin{tabular}{cccccc} 
Equipment Make & Equipment Type & Fuel type & Amount & Units & $\begin{array}{c}\text { Engine } \\
\text { Power }\end{array}$ \\
\hline Case 580 Super L & Backhoe & Diesel & 32 & $\mathrm{hrs}$ & $55 \mathrm{~kW}$ \\
Catepillar 515 & Log Skidder & Diesel & 3.5 & $\mathrm{hrs}$ & $118 \mathrm{~kW}$ \\
Chevrolet 500 & Flatbed Truck & Gasoline & $1 * 151$ & $\mathrm{p} * \mathrm{mi}$ & - \\
Honda eu 2000i & Generator & Diesel & 20 & $\mathrm{hrs}$ & - \\
John Deere 135 D & Excavator & Diesel & 36 & $\mathrm{hrs}$ & $69.4 \mathrm{~kW}$ \\
John Deere 1023E & Compact Tractor & Diesel & 19 & $\mathrm{hrs}$ & $16.5 \mathrm{~kW}$ \\
Takeuchi TB 175 & Excavator & Diesel & 27 & $\mathrm{hrs}$ & $48.2 \mathrm{~kW}$ \\
Stihl KM 94 R & Hedge Trimmer & Gasoline & 14 & $\mathrm{hrs}$ & - \\
Stihl 261 & Chainsaw & Gasoline & 16 & $\mathrm{hrs}$ & - \\
Stihl HT 250 & Pole Saw & Gasoline & 14 & $\mathrm{hrs}$ & - \\
Bobtail Truck & Single Unit Truck & Diesel & $22400 * 15$ & $\mathrm{lbs} * \mathrm{mi}$ & -
\end{tabular}

\subsubsection{Life cycle impact assessment (LCIA)}

Data were gathered in excel spreadsheets and entered into the LCA modeling software package OpenLCA 1.7.0 (Greendelta 2018) which was used to estimate the environmental impacts to air, water, and soil from the stream restoration process. Data outputted from the OpenLCA program were representative of restoring one meter of stream. The system boundaries were limited to the activities associated with raw material production, transportation to the site, and on-site construction.

The LCIA was summarized using the TRACI 2.1 (Tool for the Reduction and Assessment of Chemical and other environmental Impacts) impact assessment methodology which was developed by the US Environmental Protection Agency (Bare, 2011). The environmental impacts were grouped into ten categories including: photochemical ozone formation, acidification, global warming, eutrophication, respiratory effects, human Health-noncarcinogenics, human health-carcinogenics, ecotoxicity, ozone depletion, and resource depletionfossil fuels. Each environmental impact category was calculated relative to a reference unit photochemical ozone formation (ozone, $\mathrm{kg} \mathrm{O}_{3}$ eq.), acidification (sulfur dioxide, $\mathrm{kg} \mathrm{SO}_{2}$ eq.), 
global warming (carbon dioxide, $\mathrm{kg} \mathrm{CO}_{2}$ eq.), eutrophication (nitrogen, $\mathrm{kg} \mathrm{N}$

eq.), respiratory effects (particulate matter $>2.5$ microns, PM 2.5), ozone depletion

(trichlorofluoromethane, kg CFC-11 eq.), resource depletion- fossil fuels (MJ surplus). Human

Health-non-carcinogenics and human health-carcinogenics categories were measured in units of comparative toxic units for humans $\left(\mathrm{CTU}_{\mathrm{h}}\right)$. Ecotoxicty is measured in units of comparative toxic units for the ecosystem $\left(\mathrm{CTU}_{\mathrm{e}}\right)$.

Baseline LCIA results were presented as non-normalized results and as normalized by the US 2008 (Person/Year) normalization factor. This expressed the results in relation to the amount of impacts emitted by the average US citizen in 2008. Which allowed for a comparison between impact categories and an expression of results that were more relatable to interested parties.

\subsubsection{Key Contributor Analysis}

The key contributors were identified for each one of the impact categories within the TRACI 2.1 impact methodology. Hotspots within each respective impact category by using a contribution tree and Sankey diagram function in OpenLCA 1.7.0 (Greendelta 2018). Furthermore, a sensitivity analysis was conducted to identify hot spots and assess which parameters were the most impactful to the model. During the sensitivity analysis baseline model parameters were decreased by $25 \%$.

\subsection{Scenario Analysis}

Four separate scenarios were created by varying the baseline scenario. The alder scenario modeled the impacts associated with using the accelerated recruitment technique, which directly falls trees into the channel from the streambank. The plant sourcing scenario modeled the impacts associated with alternative plant sourcing techniques. The materials transportation scenario modeled the impacts associated with a two-fold increase in the transportation distance (see appendix, Table A2). 


\subsubsection{Alder Scenario (AS 50\% and AS 100\%)}

This scenario assumed that the LSCR would use the accelerated recruitment method. The accelerated recruitment technique involves falling red alders (Alnus rubra), which may be growing on the streambank or floodplain. Once these trees are felled they are placed unanchored into the stream to modify flow (Carah et al., 2014). This scenario compared the baseline scenario with: (1) a scenario which cut the amount of imported raw materials (i.e. logs, boulders, rootwads, metal couplers) and excavator operating time required to install wood features by $50 \%$ (AS 50\%). (2) a scenario which did not import any raw materials and cut the excavator operating time required to install wood features by $75 \%$ (AS10\%) (Table 6).

\subsubsection{Plant Sourcing (PS)}

This scenario assumed that the plants were sourced from a nearby plant nursery and quantified the impacts from growing plants in a nearby greenhouse and transporting plants to the restoration site. The number of plants grown in the greenhouse reflect the number of plants which were used to conduct revegetation in the LSCR. Plants for the greenhouse scenario were assumed to be 20 $\%$ trees (weighing $10 \mathrm{lbs}$. each), $30 \%$ mid-sized plants (weighing 5 lbs. each), and 50\% smaller shrubs (weighing 1 lbs. each) (Table 6).

\subsubsection{Materials Transportation (MT)}

This scenario quantified the impacts resulting from a two-fold increase in transportation distance. The haul distance for materials used in installing wood features was doubled. This scenario was added because many river restoration projects may take place along remote sections of stream were access is challenging. There was no change to material weights (Table 6). 
Table 6. Summary of the scenario analysis.

\begin{tabular}{|c|c|c|c|c|}
\hline Scenario & Description & Material Produciton & Transportation & On-Site Construction \\
\hline AS $50 \%$ & $\begin{array}{l}\text { Used a greater } \\
\text { degree of in-situ } \\
\text { trees to build LWCs }\end{array}$ & $\begin{array}{l}\text { Produced half of the } \\
\text { materials used to contruct } \\
\text { LWCs }\end{array}$ & $\begin{array}{l}\text { Imported half of the of } \\
\text { the materials used in to } \\
\text { constuct LWCs }\end{array}$ & $\begin{array}{c}\text { Operation time requrie to } \\
\text { installing wood features } \\
\text { was cut by } 50 \%\end{array}$ \\
\hline AS $100 \%$ & $\begin{array}{l}\text { Used only in-situ } \\
\text { trees to build LWCs }\end{array}$ & $\begin{array}{l}\text { Produced no materials } \\
\text { required to construct } \\
\text { LWCs }\end{array}$ & $\begin{array}{l}\text { No LWC materials } \\
\text { were imported }\end{array}$ & $\begin{array}{c}\text { Operation time requrie to } \\
\text { installing wood features } \\
\text { was cut by } 75 \%\end{array}$ \\
\hline PS & $\begin{array}{l}\text { Used greenhouse } \\
\text { grown plants }\end{array}$ & $\begin{array}{l}\text { Replaced excavation of } \\
\text { local plants with } \\
\text { greenhouse grown plants }\end{array}$ & $\begin{array}{l}\text { Estimated the weights } \\
\text { of plants and haul } \\
\text { distances to transport } \\
\text { materials from a }\end{array}$ & $\begin{array}{l}\text { Assumed no changes in } \\
\text { on-site revegetation }\end{array}$ \\
\hline MT & $\begin{array}{l}\text { Doubles the } \\
\text { transportaiton } \\
\text { distance }\end{array}$ & $\begin{array}{c}\text { No change to material } \\
\text { production }\end{array}$ & $\begin{array}{l}\text { Doubled transportation } \\
\text { distance }\end{array}$ & $\begin{array}{l}\text { Assumed no changes to } \\
\text { on-site construction }\end{array}$ \\
\hline
\end{tabular}

\subsection{Quantifying Environmental Performance}

This section describes the methodology for how the total station surveys were conducted, how the DEMs were created, and how the TDI was calculated. Additionally, this section describes how the TDI was incorporated with the LCA results to quantify the environmental performance of the LSCR. Figure 2 shows the general outline for this section.

\subsubsection{Total Station Surveys}

A total station was used to collect topographic survey data for phase I in the summer 2014 (preproject) and spring 2015 (post-project). Similarly, in phase II, a total station was used to collect topographic survey data in summer 2015 (pre-project) and summer 2016 (post-project). These surveys focused on capturing the topography of the active channel, nearby streambanks, and adjacent floodplain surfaces. Major break lines were shot, including the top-of-bank, bottom-ofbank, and thalweg. Additionally, a point cloud was shot between these break lines. The break lines and point cloud were intended to capture the major morphologic features of the study 
reaches. There were 1,000-1,500 points shot in each survey. Each point recorded the northing, easting, and elevation of that specific location. Once these data were collected they were offloaded into excel spreadsheets and checked for quality and data gaps.

\subsubsection{DEMs}

In phase I, the point cloud was used to build a triangular irregular network (TIN) surface AutoCAD Civil 3D by the project manager. The TIN surfaces were built by importing the point cloud and break lines in the phase I total station survey. Breaklines for the top-of-bank, bottomof-bank, and the thalweg were drawn on the TIN surface to add definition to the features. Once the breaklines were added, the TIN surface served as the base-layer for the DEMs. Similarly, in phase II, the point cloud was used to build a TIN surface in ArcMap v. 10.2.2 by the author. The TIN surfaces were built by importing the point cloud and break lines collected in the phase II total station survey. The TIN surfaces were built using the 3D Analyst and TIN editing toolbars in ArcMap. To increase the definition of the DEMs, break lines were drawn along the top-of-bank, bottom-of-bank, and thalweg. There were four DEMs created, one from each survey period (i.e. summer 2014, spring 2015, summer 2015, and summer 2016).

\subsubsection{Topographic Diversity Index (TDI) Percent Change}

The base-layer DEM was used to quantify the project effectiveness by adapting the concept of Shannon's Diversity Index (referred to as Topographic Diversity Index (TDI)). To adapt the topographic data: (1) the base layer DEM was reclassified into one-foot elevation categories; (2) the area within each one-foot category was considered a distinct category in Equation 1; (3) the total TDI was summed for each DEM.

Eq. $1 T D I=-\sum_{i=1}^{R}\left(P_{\mathrm{i}}\right) \operatorname{Ln}\left(\mathrm{P}_{\mathrm{i}}\right)$

Where: 
$P_{i}$ equals a proportion between of area within a given individual category and the total area in all categories

$\mathrm{R}$ equals the total number categories

This equation served as a quantitative indicator for the effectiveness of the LSCR and helped establish a functional unit of study for the LCA (Figure 2). This methodology allowed for a speedy quantification of the project benefits, as increasing habitat complexity is often a goal of SHI projects and is especially beneficial for salmonids (Solazzi et al., 2000; Hafs et al., 2014).

\subsubsection{Environmental Performance}

The environmental performance of phase I and II were quantified by calculating the percent TDI change and by dividing the baseline results by that factor. This scaled result approximates the amount of impacts required to create a $1 \%$ TDI change. Using the environmental performance as the end point of this study, fuses the LCA results with a quantifiable measure of restoration success. This gives LCA practitioners a flavor of the functionality of SHI and incorporates a common hydrologic monitoring technique into the backdrop of a LCA study. Figure 2 shows a schematic of the last step of this analysis. 


\section{Results}

\subsection{Baseline LCIA}

The LCIA results for the phase I and II baseline scenarios are reported on a per meter basis in Table 5. Phase I had $\approx 312$ overall impact, while phase II had $\approx 236$ overall impact. Phase II had lower impacts across all impact categories. In phase I, the normalized results (US 2008

[Person/Year]) assign the highest impacts to human health-carcinogenics, followed by: resource depletion, ecotoxicity, photochemical ozone formation, global warming, acidification, eutrophication, human health- non-carcinogenics, respiratory effect, and ozone depletion. In phase II the highest impacts were associated with human health-carcinogenics, followed by ecotoxicity, global warming, resource depletion, photochemical ozone formation, human health non-carcinogenics, eutrophication, acidification, respiratory effects, and ozone depletion (Table 7).

Table 7. Non-normalized and normalized LCIA results for restoring one meter of stream.

\begin{tabular}{lcccc} 
& \multicolumn{2}{c}{ Non-Normalized } & \multicolumn{2}{c}{ Normailzed \% } \\
\cline { 2 - 5 } Impact Category & Phase I & Phase II & Phase I & Phase II \\
\hline Human Health-Carcinogenics (CTUh) & $1.77 \mathrm{E}-06$ & $1.20 \mathrm{E}-06$ & 0.035 & 0.024 \\
Resource Depletion-Fossil Fuels (MJ surplus) & 118.57 & 64.63 & 0.0070 & 0.0038 \\
Ecotoxicity (CTUe) & 77.27 & 70.66 & 0.0070 & 0.0063 \\
Photochemical Ozone Formation (kg O3 eq) & 6.47 & 4.39 & 0.0046 & 0.0031 \\
Global Warming (kg CO2 eq) & 109.42 & 96.01 & 0.0045 & 0.0040 \\
Acidification (kg SO2 eq) & 0.26 & 0.17 & 0.0029 & 0.0019 \\
Eutrophication (kg N eq) & 0.063 & 0.045 & 0.0028 & 0.0021 \\
Human Health- Non-Carcinogenics (CTUh) & $2.64 \mathrm{E}-06$ & $2.50 \mathrm{E}-06$ & 0.0026 & 0.0024 \\
Respiratory Effects (kg PM2.5) & 0.025 & 0.018 & 0.0011 & 0.0008 \\
Ozone Depletion (kg CFC-11 eq) & $1.41 \mathrm{E}-05$ & $7.66 \mathrm{E}-06$ & 0.0001 & 0.0000 \\
\hline Total & $\mathbf{3 1 2 . 0 8}$ & $\mathbf{2 3 5 . 9 2}$ & $\mathbf{0 . 0 7}$ & $\mathbf{0 . 0 5}$
\end{tabular}




\subsection{Key Contributors to Impacts}

The key contributors to environmental impacts were estimated for human health-carcinogenics, photochemical ozone formation, global warming, acidification, ecotoxicity, eutrophication, human health non-carcinogenics, respiratory effects, resource depletion, and ozone depletion for both phase I and II. The impact categories are listed here in order of greatest magnitude according to the US 2008 [Person/Year] normalization and weighting factor.

\subsubsection{Key Contributors to Impacts in Phase I}

\subsubsection{Human Health- Carcinogenics}

The contributions are primarily from installing wood features, installing off-channel features, and transporting heavy equipment which make up account for $\approx 55 \%, \approx 15 \%$, and $\approx 15 \%$ of the impacts, respectively. In the installing wood feature and installing off-channel feature processes most of the impacts are associated with machine building. Machine building is upstream of the machinery operation process which modeled the operation of a large excavator (Hyundai 140 LCD-7) used to construct LWCs. Similarly, a metal working process was another hotspot in the wood feature construction, which was used to model the production of flexible couplers used to join LWCs. The impacts from transporting heavy-equipment were attributed the haul trucks used to transport the equipment (Figure 5).

\subsubsection{Resource Depletion-Fossil Fuels}

The majority of impacts stem from installing wood features, off-channel features, and heavy equipment transportation which account for $\approx 52 \%, \approx 25 \%$, and $\approx 15 \%$ of impacts, respectively. In installing wood features and off-channel features much of impacts stem from the operation of a large excavator (Hyundai 140 LCD-7). The upstream petroleum refinery operation was responsible for most of the impacts. This excavator had high fuel demands and had the highest operation hours. Similarly, in revegetation, most of the impacts were associated with the 
operation of a mid-sized backhoe. Which was used to excavate soil binding species which were planted along disturbed areas in the LSCR. The upstream manufacturing of diesel was a hotspot within heavy equipment operation processes (Figure 5).

\subsubsection{Ecotoxicity}

Much of impacts came from installing wood features, installing off-channel features, and heavy equipment transport, which account for $\approx 55 \%, \approx 15 \%$, and $\approx 14 \%$, respectively. Much of the impacts associated with installing wood features are from the operation of a large excavator (Hyundai 140 LCD-7), particularly the building of the machinery. Additionally, a metal working process upstream of the metal coupler production was a hotpot within installing wood features. The impacts associated with metal coupler production were from steel product manufacturing. In heavy equipment transport, the impacts were associated with the operation of haul trucks (Figure $5)$.

\subsubsection{Photochemical Ozone Formation}

The contributions are from installing wood features and off-channel features, which account for $\approx 52 \%$ and $\approx 22 \%$ of impacts, respectively. In both installing wood features and off-channel features most of the impacts were associated with the operation of heavy equipment, particularly a large excavator (Hyundai 140 LCD-7). Excavators were used to place LWCs and excavate offchannel features (Figure 5).

\subsubsection{Global Warming}

The primary contributions are primarily from installing wood features and off-channel features, which account for $\approx 73 \%$ and $\approx 13 \%$ of impacts, respectively. In installing wood features most of impacts are from the harvesting of redwoods in the material production phase of the LSCR.

Harvesting redwood accounted for $\approx 46 \%$ of the global warming impacts. In both installing wood features and installing off channel features impacts stem from excavator operation (Hyundai 140 LCD-7) (Figure 5). 


\subsubsection{Acidification}

The primary contributions are from primarily from installing wood feature and off-channel, which account for $\approx 52 \%$ and $\approx 22 \%$ of impacts, respectively. Most of the impacts were associated with the operation of a large excavator (Hyundai 140 LCD-7). The large excavator was used to create off-channel features and place LWCs in the stream. Upstream processes for diesel production was responsible for most of impacts (Figure 5).

\subsubsection{Eutrophication}

Most of the impacts came from installing wood features, installing off-channel features, and revegetation which account for $\approx 53 \%, \approx 20 \%$, and $\approx 13 \%$ of impacts, respectively. In installing wood features and off-channel features of the LSCR, operating a large excavator (Hyundai 140 LCD-7) was the key contributor to impacts in these processes. In revegetation, the operation of mid-sized backhoe (Case 580 Super L) was the key contributor to impacts. In all three of these processes, most of the impacts are associated with diesel manufacturing, a process upstream of the operation of diesel-powered machinery (Figure 5).

\subsubsection{Human Health- Non-Carcinogenics}

Most of the impacts stem from installing wood features, installing off-channel features, and heavy equipment transport which account for $\approx 55 \%, \approx 15 \%$, and $\approx 15 \%$, respectively. In installing wood features and off-channel features most of the impacts stem from machine building upstream of operating a large excavator (Hyundai 140 LCD-7). In installing wood features a secondary source of impacts stem from steel product manufacturing. Steel product manufacturing is associated with the production of metal couplers used to join LWC components. In heavy equipment transport the majority of impacts stem from operating diesel-powered haul trucks. (Figure 5).

\subsubsection{Respiratory Effects}

Impacts stem from installing wood features and installing off-channel features, which account for $\approx 53 \%$ and $\approx 21 \%$, respectively. In both processes the majority of impacts stem from operating a 
large excavator (Hyundai 140 LCD-7). More specifically, diesel manufacturing was responsible for most of the impacts (Figure 5).

\subsubsection{Ozone Depletion}

Ozone depletion impacts stem from installing wood features, installing off-channel features, and revegetation which accounts for $\approx 51 \%, \approx 25 \%$, and $\approx 15 \%$ of impacts, respectively. In installing wood features and off-channel features of the LSCR, operating a large excavator (Hyundai 140 LCD-7) was the key contributor to impacts in these processes. Similarly, in revegetation, the operation of mid-sized backhoe (Case 580 Super L) was the key contributor to impacts. In all three of these processes most of the impacts are associated with diesel manufacturing, a process upstream of the operation of diesel-powered machinery (Figure 5).

\subsubsection{Key Contributors to Impacts in Phase II}

\subsubsection{Human Health- Carcinogenics}

Impacts stem from installing wood features and revegetation activities, which make up account for $\approx 62 \%$ and $\approx 17 \%$ of the impacts, respectively. In installing wood features most of the impacts are from metal coupler production, particularly associated with a steel metal working process. A secondary source contributor in the installing wood features process was the operation of haul trucks, which were used to haul materials from the factory gate to the job site. In revegetation activities, much of the impacts are from the operation of mid-sized backhoe operation (Case 580 Super L) (Figure 5).

\subsubsection{Ecotoxicity}

Most of the impacts came from installing wood features and heavy equipment transport, which account for $\approx 63 \%$ and $\approx 17 \%$, respectively. Within the installing wood feature process, most of the impacts are associated with raw material transportation and metal coupler production. In both installing wood features and heavy equipment transport impacts are associated with the operation 
of haul trucks which moved raw materials and haul heavy equipment to the site. Also, metal coupler production was a key contributor to impacts in the installing wood features process. In metal coupler production the impacts are associated with a steel metal working process (Figure $5)$.

\subsubsection{Global Warming}

The overwhelming majority of impacts are from installing wood features, which account for $\approx 82 \%$ of impacts. Within this process much of impacts stem from the harvest of redwood logs, which account for $\approx 66 \%$ of the global warming impacts. Secondary to redwood log harvest, impacts stem from the operation of haul trucks (Figure 5).

\subsubsection{Resource Depletion-Fossil Fuels}

Much of impacts are from installing wood features, revegetation activities, and transporting heavy equipment, which account for $\approx 48 \%, \approx 25 \%$, and $\approx 14 \%$, respectively. Within these processes much of impacts stem from the operation of haul trucks, with secondary contributions from heavy equipment operation. Upstream refinement of petroleum projects is a consistent hotspot in both haul truck and heavy equipment operation (Figure 5).

\subsubsection{Photochemical Ozone Formation}

The majority of impacts stem from installing wood features, revegetation activities, and transporting heavy equipment, which account for $\approx 53 \%, \approx 17 \%$, and $\approx 16 \%$, respectively. Much of impacts stem from operating large haul tucks used to transport heavy equipment and raw materials. Impacts also stem from the onsite operation of diesel-powered heavy equipment. In all three categories impacts are associated with upstream diesel production (Figure 5).

\subsubsection{Human Health- Non-Carcinogenics}

The majority of impacts stem from installing wood features and transporting heavy equipment, which account for $\approx 64 \%$ and $\approx 18 \%$, respectively. Within these processes most of the impacts 
stem from transporting heavy equipment and raw materials, which used large haul trucks. Within installing wood features, metal coupler production was a substantial contributor to impacts, which was associated with an upstream steel metal working process (Figure 5).

\subsubsection{Eutrophication}

The majority of impacts stem from installing wood features and revegetation activities, which account for $\approx 57 \%$ and $16 \%$, respectively. In installing wood features most of the impacts are from transporting raw materials and metal coupler production. In revegetation activities, the majority of impacts stem from the operation of a mid-sized backhoe (Case 580 Super L) which was used to excavate plants for erosion control. In transportation of raw materials and heavy equipment operation the majority of impacts stem from upstream petroleum production (Figure 5).

\subsubsection{Acidification}

The majority of impacts stem from installing wood features, revegetation activities, and transporting heavy equipment, which account for $\approx 54 \%, \approx 18 \%$, and $\approx 15 \%$, respectively. Within installing wood features and transport heavy equipment much of impacts stem from the operation of haul trucks. In revegetation activities, the majority of impacts stem from the operation of a mid-sized backhoe (Case 580 Super L) (Figure 5).

\subsubsection{Respiratory Effects}

The majority of impacts stem from installing wood features, transporting heavy equipment, and revegetation activities, which account for $\approx 57 \%, \approx 16 \%$, and $\approx 15 \%$, respectively. Within installing wood features and transporting heavy equipment most of impacts stem from using haul trucks to move materials and equipment to and from the site. In revegetation activities, the majority of impacts stem from the operation of a mid-sized backhoe (Case 580 Super L) (Figure 5). 


\subsubsection{Ozone Depletion}

The majority of the impacts stem from installing wood features, transporting heavy equipment, and revegetation activities, which account for $\approx 47 \%, \approx 25 \%$, and $\approx 14 \%$, respectively. Within installing wood features and transporting heavy equipment, the majority of impacts stem from using haul trucks to move materials and equipment to and from the site. In revegetation activities, most of impacts stem from the operation of a mid-sized backhoe (Case 580 Super L) (Figure 5).

\subsubsection{Sensitivity Analysis}

\subsubsection{Phase I}

The LCA model was most sensitive to the amount of time spent operating a large excavator (Hyundai 140 LCD-7), the amount of redwoods which were harvested, and the time spent operating a mid-sized backhoe (Case 580 Super L). Reducing 25\% of the excavator operating time led to a $7 \%$ decrease in overall environmental impacts. Reducing the amount of redwoods which were harvested by $25 \%$ led to $4 \%$ decrease in overall environmental impacts. Reducing the backhoe operating time by $25 \%$ led to $3 \%$ decrease in overall environmental impacts (see appendix, Table A3).

\subsubsection{Phase II}

The LCA model was most sensitive to the amount of redwoods harvested, the time spent on a mid-sized backhoe (Case 580 Super L), and the number of boulders which were quarried and delivered to the job site. Reducing the amount of redwood harvests by $25 \%$ led to a $7 \%$ decrease in the overall environmental impacts. Reducing $25 \%$ of backhoe operating time led to $3 \%$ decrease in overall environmental impacts. Reducing the number of boulders which were transported by to the site by $25 \%$ reduced the impacts by $\approx 3 \%$, while cutting the number of boulders which were quarried reduced the impacts by $\approx 2.9 \%$ (see appendix, Table A4). 


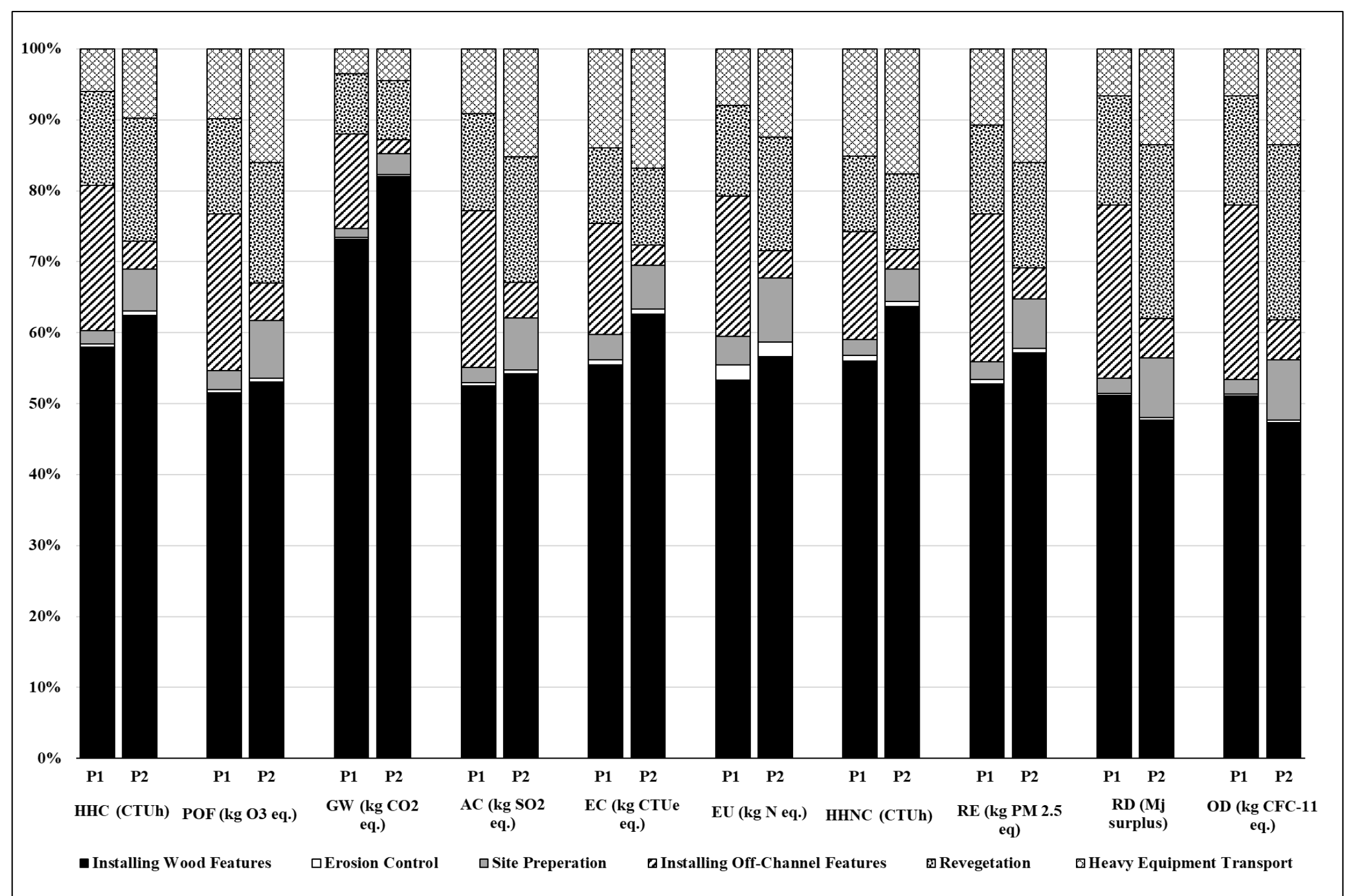

Figure 5. Key contributors to environmental impacts in Human Health-Carcinogenics (HHC), Photochemical Ozone Formation (POF), Global Warming (GW), Acidification (AC), Ecotoxicity (EU), Eutrophication (EU), Human Health Non-Carcinogenics (HHNC), Respiratory Effects (RE), Resource Depletion (RE), and Ozone Depletion (OD) in Phase I (P1) and Phase II (P2). 


\subsection{Scenario Analysis}

Figure 6 summarized the impacts from five scenarios in both phases I and II. On a per meter basis the overall impacts for the AS 50\% were $\approx 218$ and $\approx 159$ in phases I and II, respectively. For the AS $100 \%$ total impacts were $\approx 148$ and $\approx 83$ in phases I and II, respectively. In the PS $100 \%$ total impacts were $\approx 281$ and $\approx 210$ in phases I and II, respectively. In the MT total impacts were $\approx 325$ and $\approx 272$, respectively. The AS $50 \%$ reduced the overall environmental impacts by $30 \%$ in phase I and $33 \%$ in phase II. The AS $100 \%$ reduced overall environmental impacts by $52 \%$ in phase I and $65 \%$ in phase II. The PS reduced overall environmental impacts by $10 \%$ in phase I and $11 \%$ in phase II. The MT increased the overall environmental impacts by $4 \%$ in phase I and $15 \%$ in phase II (Figure 6). 


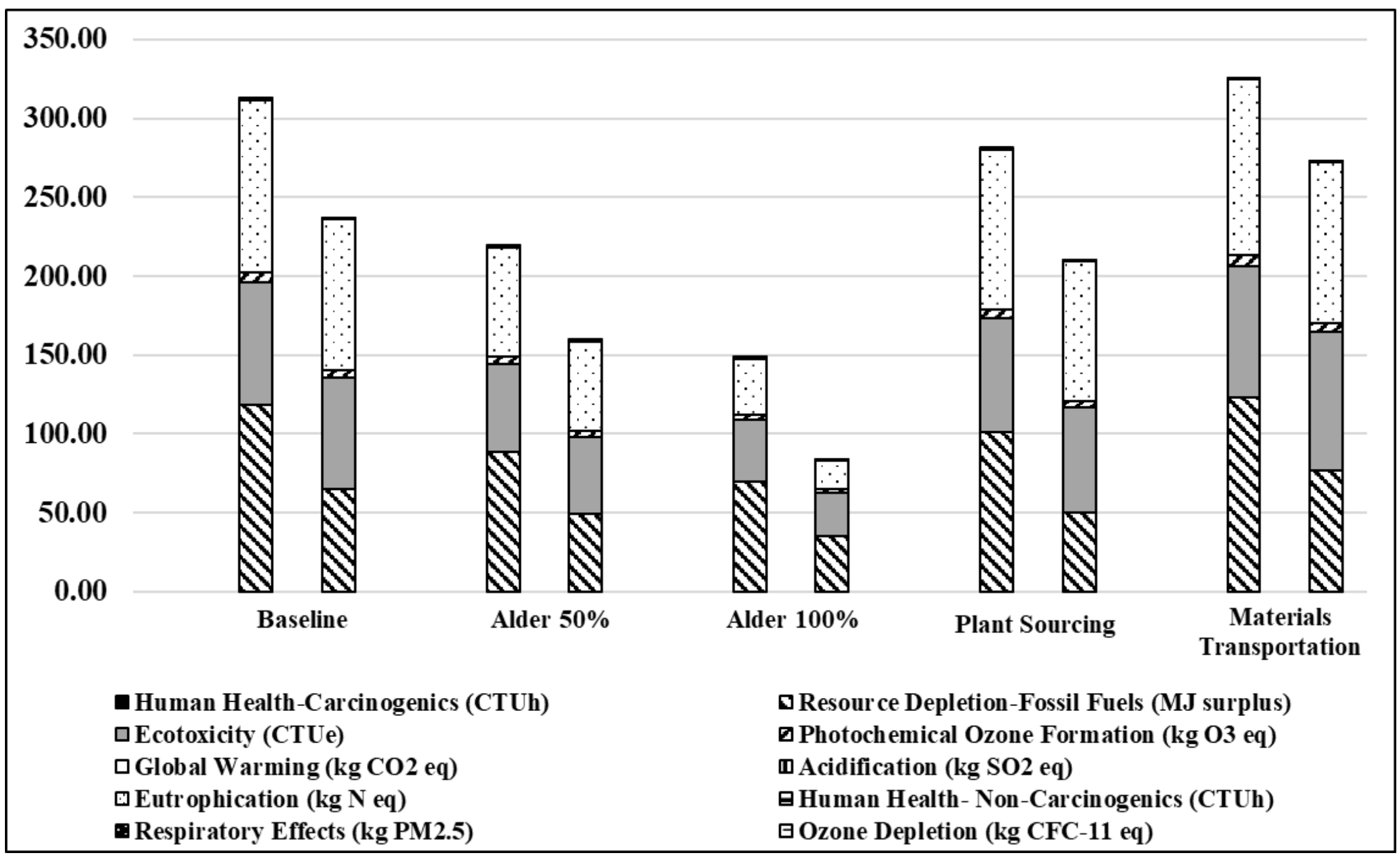

Figure 6. Quantifies the overall environmental impacts from the baseline, Alder 50\% (AS 50\%), Alder 100\% (AS 100\%), Plant Sourcing (PS), and Materials Transportation (MT) scenarios. 


\subsection{TDI Change}

The $\%$ TDI increase was nearly identical in each reach. TDI value increased by $0.145(7.7 \%)$ in phase I and $0.150(7.9 \%)$ in phase II (Table 4). Figure 7 shows the DEM and positioning of the LWC in both phase I and II. Overall, phase II had a greater TDI change, although the change was very similar. The TDI change was very similar despite the different water years, phase I experience only one bankful event, while phase II experienced several. The bulk of this section focused on the pool development because it was a main goal of the LSCR.

There were LWCs in both phase I and II that were strongly associated with deep pool formation (Figure 7). LWC 3 ( $3^{\text {rd }}$ LWC from the downstream end, see figure 7) in phase I generated a deep pool (residual pool depth of $\approx 3.1$ feet) near the tip of the structure. Due to the depth and defined nature of the pool downstream of LWC 3-phase I, the general design was mimicked in all four of the LWCs in phase II. LWC 3-phase I was constructed with a rootwad fastened by a metal coupler just downstream of the tip of the redwood log and boulder ballast upstream of the tip of

the redwood $\log$ (Figure 8). This design was dubbed "franken-log" because it mimicked the form of a living tree. The metal couplers flexible connection allowed the rootwad to lift during high flows. Theoretically, this action forced water beneath the rootwad and initiated scour into the channel bed.

LWC 2 in phase II and LWC 3 in phase II generated deep pools at the downstream end of the logs, with residual pool depths measuring $\approx 4.3 \mathrm{ft}$. and $\approx 3.2 \mathrm{ft}$. (Figure 7 ), respectively. The amount of scour that these features achieved contributed to TDI increases in and II. Additionally, the pool that formed downstream of LWC 3-phase II was likely influenced by a "semi-natural" alder recruit. This large multi stemmed alder recruit fell in March 2016, it had a very large rootwad and spanned the entire active channel. It is very likely that LWC 3-phase II initiated migration of thalweg towards the right-bank which helped generate the erosion that caused the alder clump to fall. 
Aside from forming deeper pool habitat these structures tended to break up stream flow. When the stream flow was disrupted a slow-water area often formed downstream and behind LWCs. In these slow-water areas generally led to an accumulation of material in the slow-water areas.

These depositional features were noted on the left bank of behind LWC-4 in phase I and on the left bank behind LWC-4 in phase II. The subsequent deposition and erosion led to an increase in TDI in both phase I and II.

Table 6. Area (ft2) and TDI value for each elevation category in phase I and II of the LSCR.

\section{Phase I}

Pre-Installation Post-Installation

\begin{tabular}{ccccccc}
\hline \hline $\begin{array}{c}\text { Elevation } \\
\text { Category }\end{array}$ & Area $\left(\mathbf{f t}^{\mathbf{2}}\right)$ & TDI & & $\begin{array}{c}\text { Elevation } \\
\text { Category }\end{array}$ & Area $\left(\mathbf{f t}^{\mathbf{2}}\right)$ & TDI \\
\cline { 6 - 7 } & & - & & $7.66-8$ & 39 & 0.009 \\
$8.47-9$ & 177 & 0.032 & & $8--9$ & 453 & 0.066 \\
$9--10$ & 2283 & 0.203 & & $9--10$ & 3292 & 0.250 \\
$10--11$ & 5838 & 0.326 & & $10--11$ & 5122 & 0.309 \\
$11--12$ & 10705 & 0.368 & & $11--12$ & 7812 & 0.355 \\
$12--13$ & 4139 & 0.281 & & $12--13$ & 5318 & 0.314 \\
$13--14$ & 2276 & 0.203 & & $13--14$ & 3554 & 0.260 \\
$14--15$ & 1632 & 0.165 & $14--15$ & 1582 & 0.161 \\
$15--16$ & 930 & 0.112 & $15--16$ & 943 & 0.113 \\
$16--17$ & 271 & 0.045 & & $16--17$ & 249 & 0.042 \\
\hline Total & $\mathbf{2 8 2 5 1}$ & $\mathbf{1 . 7 3 5}$ & Total & $\mathbf{2 8 3 6 4}$ & $\mathbf{1 . 8 7 9}$
\end{tabular}

Phase II

Pre-Installation

Post-Installation

\begin{tabular}{cccccc}
\hline \hline $\begin{array}{c}\text { Elevation } \\
\text { Category }\end{array}$ & Area $\left(\mathbf{f t}^{\mathbf{2}}\right)$ & TDI & $\begin{array}{c}\text { Elevation } \\
\text { Category }\end{array}$ & Area $\left(\mathbf{f t}^{\mathbf{2}}\right)$ & TDI \\
\hline- & - & - & $8.45--9$ & 59 & 0.01472 \\
$9.91-10$ & 1 & 0.000 & $9--10$ & 241 & 0.046 \\
$10--11$ & 145 & 0.031 & $10--11$ & 488 & 0.079 \\
$11--12$ & 1025 & 0.134 & $11--12$ & 1378 & 0.164 \\
$12--13$ & 4318 & 0.308 & $12--13$ & 5763 & 0.342 \\
$13--14$ & 8504 & 0.368 & $13--14$ & 6118 & 0.348 \\
$14--15$ & 4637 & 0.317 & $14--15$ & 4753 & 0.320 \\
$15--16$ & 2777 & 0.249 & $15--16$ & 2790 & 0.250 \\
$16--17$ & 1728 & 0.189 & $16--17$ & 1396 & 0.165 \\
$17--18$ & 786 & 0.112 & $17--18$ & 893 & 0.122 \\
$18--19$ & 182 & 0.037 & $18--19$ & 205 & 0.041 \\
$19--20$ & 5 & 0.002 & $19--20$ & 18 & 0.005 \\
\hline Total & $\mathbf{2 4 1 0 8}$ & $\mathbf{1 . 7 4 6}$ & Total & $\mathbf{2 4 1 0 2}$ & $\mathbf{1 . 8 9 6}$
\end{tabular}



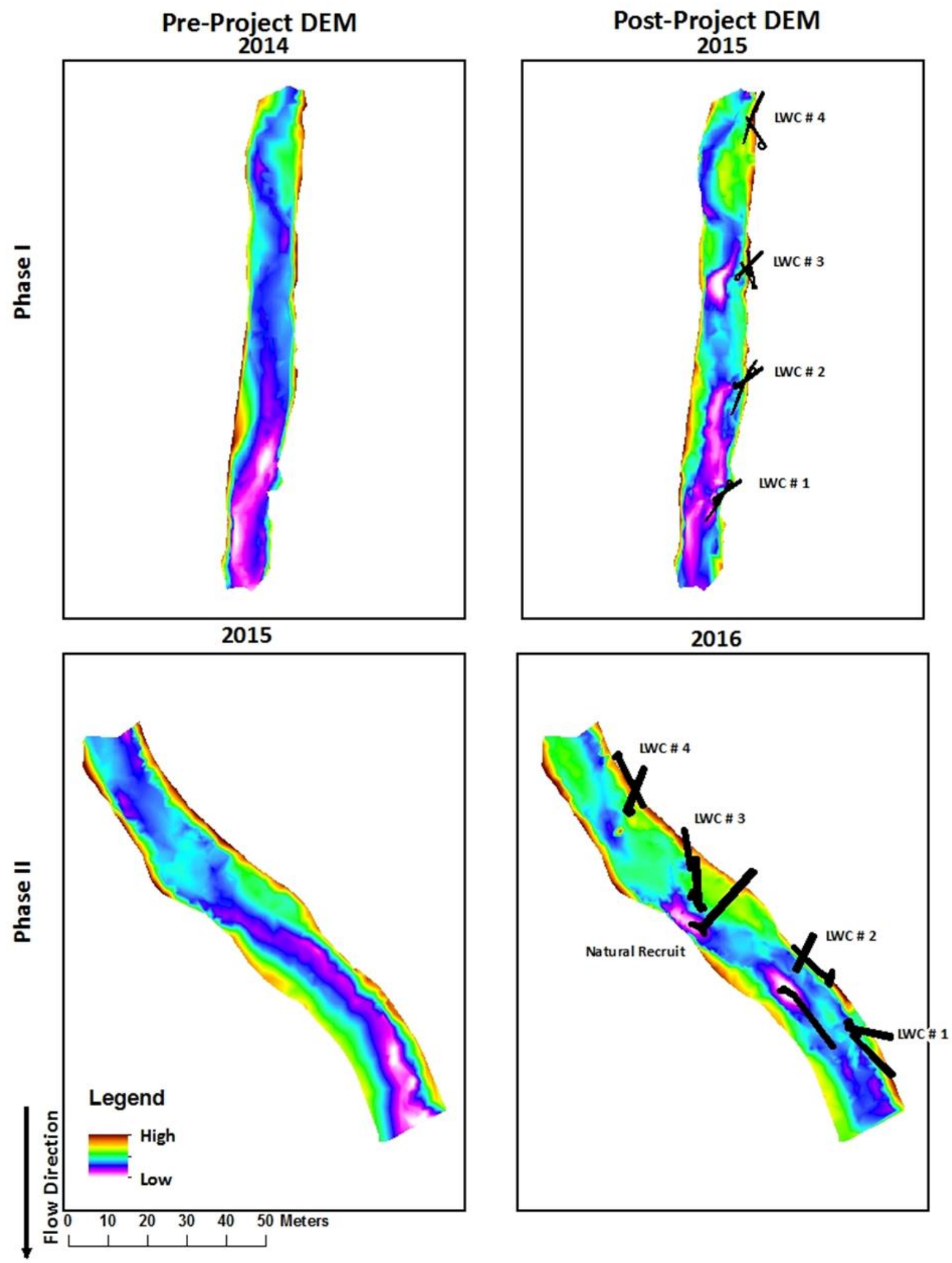

Figure 7. DEM of study reach channels for phase I (top) and phase II (bottom), pre-project survey is shown on the left, post-project survey is shown on the right. 


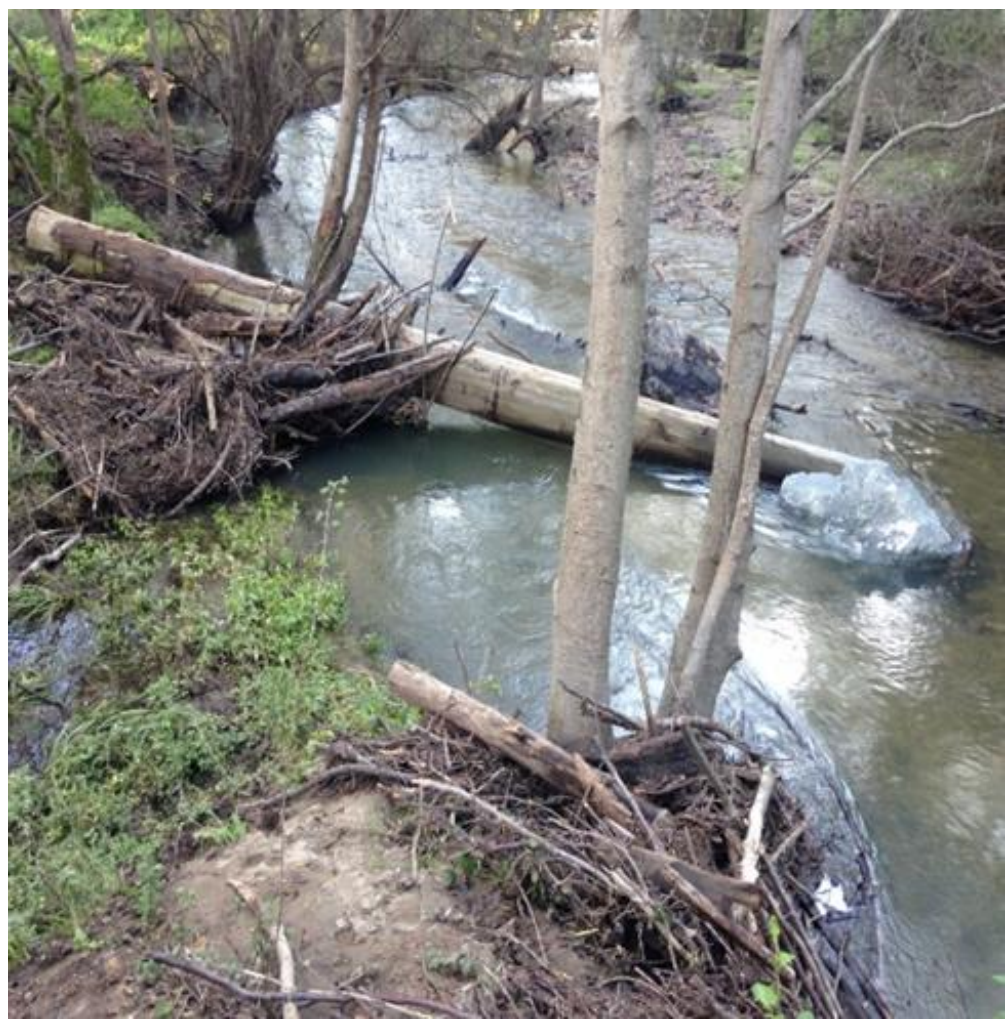

Figure 8. A picture of a franken-log LWC configuration.

\subsection{Environmental Performance}

This study incorporated TDI percent change with LCA impacts to quantify the environmental performance. Life cycle impacts were scaled to represent the a $1 \%$ TDI change. The overall environmental impacts amounted to 6479 for phase I and 3733 for phase I. Phase II performed better in all the TRACI impact categories and $43 \%$ better in overall impacts (Table 7). The TDI change amplified the existing difference in impacts between the two phases, as TDI increased by $7.9 \%$ in phase II and by $7.7 \%$ in phase I. 
Table 7. The impact assessment results scaled to reflect a $1 \%$ TDI increase functional unit in both phase I and II.

\begin{tabular}{lcc} 
& \multicolumn{2}{c}{ Environmental Performance } \\
\cline { 2 - 3 } Impact Category & Phase I & Phase II \\
\hline Human Health-Carcinogenics (CTUh) & $3.64 \mathrm{E}-05$ & $1.90 \mathrm{E}-05$ \\
Resource Depletion-Fossil Fuels (MJ surplus) & 2467.53 & 1022.63 \\
Ecotoxicity (CTUe) & 1597.40 & 1118.12 \\
Photochemical Ozone Formation (kg O3 eq) & 134.60 & 69.57 \\
Global Warming (kg CO2 eq) & 2272.73 & 1518.99 \\
Acidification (kg SO2 eq) & 5.47 & 2.78 \\
Eutrophication (kg N eq) & 1.32 & 0.72 \\
Human Health- Non-Carcinogenics (CTUh) & $5.45 \mathrm{E}-05$ & $3.92 \mathrm{E}-05$ \\
Respiratory Effects (kg PM2.5) & 0.53 & 0.30 \\
Ozone Depletion (kg CFC-11 eq) & $3.25 \mathrm{E}-04$ & $1.22 \mathrm{E}-04$ \\
\hline Total & 6479.58 & 3733.10
\end{tabular}




\section{Discussion}

\subsection{Life Cycle Interpretation}

This study aimed to quantify and identify the key contributors to the environmental impacts from installing a representative SHI project. Furthermore, this study conducted a scenario analysis to quantify the impacts associated with different LWC construction, plant material sourcing, and transportation distances. No other study to date has quantified the life cycle impacts of SHI or the river restoration process. Therefore, this study may interest river restoration managers and LCA practitioners. This section discusses the most important LCA results per the study reference unit of one meter of stream restored.

In both phases I and II, the clear majority of impacts came from installing wood features (Figure 5), which represented the greatest time- and fuel-consuming activities in the SHI process and required the largest material inputs. On a per meter basis, installing wood features was responsible for $79.5 \mathrm{~kg} \mathrm{CO}_{2}$ eq (73\%) of the global warming impact, in phase I and accounted for $78.8 \mathrm{~kg} \mathrm{CO}_{2} \mathrm{eq},(82 \%)$ of the global warming impacts in both phases II. The greatest global warming impacts were from harvesting redwood logs in the raw material phase (Figure 5). Harvesting logs was responsible for $45 \%$ of the global warming impact in phase I and $66 \%$ in phase II. Also, diesel-powered equipment such as excavators and large-haul trucks were key contributors. In phase I a large excavator was responsible for $22 \%$ of the global warming impacts. In phase II haul trucks and excavators accounted for approximately $12 \%$ of the global warming impacts. This result is echoed in the literature, where diesel combustion in heavy equipment was a large contributor to global warming impacts (Dias and Arroja, 2012; González-García et al., 2014b; a; Han et al., 2015). For example, a study of redwood production in northern California, Han et al., (2015) found that primary in-woods transportation (i.e. skidding and yarding) was responsible for the greatest impacts to global warming because of large fuel requirements. 
Activities associated with heavy equipment operation were also key contributors to impacts in photochemical ozone formation, eutrophication, and acidification. Installing wood features was responsible for just over $50 \%$ of the contributions in these impact categories. Operating large excavators was the primary contributor to photochemical ozone formation. Most impacts in acidification and eutrophication are associated with diesel manufacturing upstream of heavy equipment operation and materials hauling. Along with global warming potential, these impact categories were the most commonly quantified impact categories in the literature. Studies in forestry documented similar results. For instance, Gonzalez-Garcia et al., (2013) found that the stand thinning, roundwood forwarding and loading logs onto trucks were the most impactful activities in the aforementioned categories because of high fuel combustion in large machinery.

This study identified human health-carcinogenics as the most impactful category, and as in the other impact categories, installing wood features was the key contributor. Installing wood features accounted for 1.03E-6 CTUh eq (58\%) in phase I and for 7.44E-5 (62\%) in phase II. These impacts were most strongly associated with machinery building and steel metal working. Machinery building was upstream of all the heavy equipment operation processes. Steel metal working was required to produce metal couplers which were eventually used to join LWC components. A study by Cambria and Pierangeli (2012) documented similar results in the production of metallic fences, which also were zinc-coated and were used to fence off forest production areas. They found that the fence building process had tremendous impacts to the entire product system, but especially in photochemical oxidation, and marine, terrestrial, and freshwater ecotoxicity.

Notwithstanding many consistencies between the environmental profile of phase I and II, phase II did outperform phase I. The primary difference between the two phases was the amount of material which had to be removed to create off-channel features. Approximately, 279 cubic 
meters of material were removed in the construction of five off-channel features in phase I.

Whereas in phase II, only 92 cubic meters were removed to create one small alcove feature. The amount of removed material directly correlated with the number of trips on a dump truck and number of equipment hours. Therefore, the more material which was removed led to greater impacts because dump trucks had to make more trips (73 in phase I and 15 in phase II). For example, installing off-channel features was responsible for $\approx 25 \%$ of the impacts in resource depletion in phase I. Whereas in phase II, installing off-channel features was only responsible for $\approx 6 \%$ of the impact.

Key contributors to impacts also varied by impact category. For instance, in phase I the key contributor to ecotoxicity was the operation of a large excavator, whereas in phase II the key contributors to ecotoxicity are mining and transportation of granite boulders. This difference was due in part to the size of granite boulders. Phase II boulders were approximately $2000 \mathrm{lbs}$. heavier than phase I boulders, requiring greater efforts to quarry and transport. Excavator operation hours also varied between projects and were a key contributor in both projects. There were five more excavator hours in phase I, making it a larger contributor relative to other activities in phase I.

Although processes required to install wood features (log harvest, excavator operation) were key contributors to impacts in this SHI project, it was also central to the design of the LSCR. One way to circumvent most of the impacts associated with installing wood features is to use the accelerated recruitment method. The accelerated recruitment method cuts or excavates trees growing on or nearby the streambank and places them into the channel to modify flow regimes and increase habitat complexity. Carah et al., (2014) demonstrated the promise of this method, finding that recruited trees reliably improved habitat, retained wood over the short term, and have the potential to increase the scale and efficiency of the river restoration process. To model the impacts from using the accelerated recruitment method, this study created the 50\% and $100 \%$ 
alder scenarios (AS 50\% and AS 100\%). These scenarios assumed that red alders (Alnus rubra) growing on the streambank would be pushed, pulled, or otherwise manipulated into the channel.

The AS 50\% reduced overall impacts by $30 \%$ in phase I and $33 \%$ in phase II. The primary cause of this reduction was the limited use of large materials such as redwood logs and granite boulders which had high environmental costs in both phases of the LSCR. The AS 100\% reduced overall impacts by $\approx 53 \%$ in phase I and by $\approx 65 \%$ in phase II. This dramatic impact reduction was due to completely omitting the use of outside material in installing wood features and cutting the excavator operating time by $75 \%$. Both alder scenarios caused significant reductions in overall environmental impacts because they limited excavator operating time and upstream materials production, both of which are hotspots in SHI. Although reductions from the accelerated recruitment were expected, the striking degree of reductions was surprising, especially in phase II.

To model the impacts associated with using nursery grown plants this study created the plant sourcing scenario (PS). The overall impacts of the PS resulted in reduction by $10 \%$ in phase I and by $11 \%$ in phase II. This result was surprising because we expected increased overall impacts from the PS because the revegetation methods employed in the LSCR were time efficent. In the baseline scenario, a mid-sized backhoe was used to excavate various species of rush (Juncus spp.). This method allowed field crews to gather a large amount of plants in a short time. Furthermore, juncus species are hardy and have important soil binding and water tolerance attributes making them valuable in revegetation of disturbed areas. Using nearby native plants also preserved genetic stock because plants were removed from the same watershed. However, from a life cycle prospective, using nursery grown plants and transporting the plants a short distance proved to be less impactful in all impact categories except for eutrophication. This result should be interpreted with caution. The operation of the backhoe was responsible for 
approximately $95 \%$ of the impacts in the revegetation process. Using a backhoe to harvest plant materials was a time-saving necessity for the field crew but was not necessarily required.

Furthermore, the impacts of nursery plant use on eutrophication were increased 15 -fold compared to the baseline scenario. The heightened eutrophication potential in the PS was associated with fertilizer use in the nursery process. Also, the PS scenario used a representative nursery located only 33 miles away, thus lowering the impacts associated with hauling plant martials from the nursery to the job site. Potential impacts could vary with greater distances to a nursery. In the baseline scenario, hauling materials was a large contributor in some categories. Haul distance is directly associated with increased impacts, a finding which was confirmed in the materials transportation scenario (MT).

The MT scenario doubled the haul distance for raw materials used in installing wood features. This resulted in a $4 \%$ and $15 \%$ increase in overall impacts in phase I and II, respectively. This scenario was conducted because sources of materials in the LSCR were nearby (fewer than 100 miles away, generally). An important question leading to this assessment was, how would the model react if a manager were to import materials to a more remote location? Some river restoration projects take place along very remote sections of river which are difficult to access. From a life cycle prospective, these results strongly favor locally sourced materials.

\subsection{Maximizing Environmental Performance of SHI}

This section discusses specific ways for managers to improve the SHI process. Installing wood features was by far the most impactful phase of the LSCR. However, LWCs were key to improving instream habitat and were largely responsible for the TDI increases (Table 6 and Figure 7). Instream large wood is known to benefit salmonid habitat (Howson et al., 2012) particularly from the formation of deep pools (Roni et al., 2014). It is crucial that managers attempt to maintain the benefits that instream large wood provides, while minimizing the impacts 
associated with LWC construction. The alder scenarios in this study modeled the impacts of using the accelerated recruitment method to construct LWCs. In the accelerated recruitment method, LWCs were constructed by falling in-situ trees into the channel as unanchored wood structures.

Managers should consider using the accelerated recruitment method to a greater degree. The accelerated recruitment method can increase the scale of river restoration projects, reduce economic costs, reduce installation time, and reliably improve habitat (Carah et al., 2014). This technique was also used during the LSCR to incorporate red alders (Alnus rubra) into LWCs alongside imported materials (metal couplers, redwood logs, boulders ballasts, and rootwads). The findings from the scenario analysis suggest that impacts could be reduced by $30 \%-65 \%$ depending on the degree to which accelerated recruitment was used (Figure 6). Managers should be aware that using this technique could dramatically reduce the overall environmental impacts of a SHI project and create favorable habitat changes.

The effectiveness monitoring data also suggest a positive response from the accelerated recruitment method, particularly in phase II. LWC 3 in phase II initiated thawleg (a line connecting the lowest point of the stream) migration which caused a large multi-stemmed red alder to fall. A deep pool formed beneath the bole of this semi-natural recruit. It is likely that the size and position of this piece played a role in the creation of this pool. The alder spanned more than two times the channel width and had a diameter at breast height $(\mathrm{DBH})$ of $>70 \mathrm{~cm}$ on its largest stem. Multiple studies suggest that logs greater than 1.5 times the channel width were retained at higher rates than shorter logs (Carah et al., 2014). Another study found that logs greater than $60 \mathrm{~cm}$ in diameter tended to form a higher proportion of pools than did thinner logs (Rosenfeld and Huato, 2003). If the accelerated recruitment method is used to introduce large key pieces (which are greater than 1.5 times the channel width and are $60 \mathrm{~cm}$ in $\mathrm{DBH}$ ), then the 
ecological benefits of LWCs will be maintained and the environmental impacts would be significantly reduced.

The alder scenarios generated a dramatic reduction of environmental impacts because they limited excavator operating time, production and transport of redwood logs and boulders, and metal coupler production. Some other ways to improve the environmental performance of SHI would be to minimize operation of heavy equipment by: (1) ensuring easy clear access to the channel and streambank, (2) using small engine equipment to clear access corridors during site preparation, (3) running more fuel-efficient machinery and/or using biofuel-powered machinery (Cambria and Pierangeli, 2012), and (4) sourcing nearby materials as to minimize transportation distance.

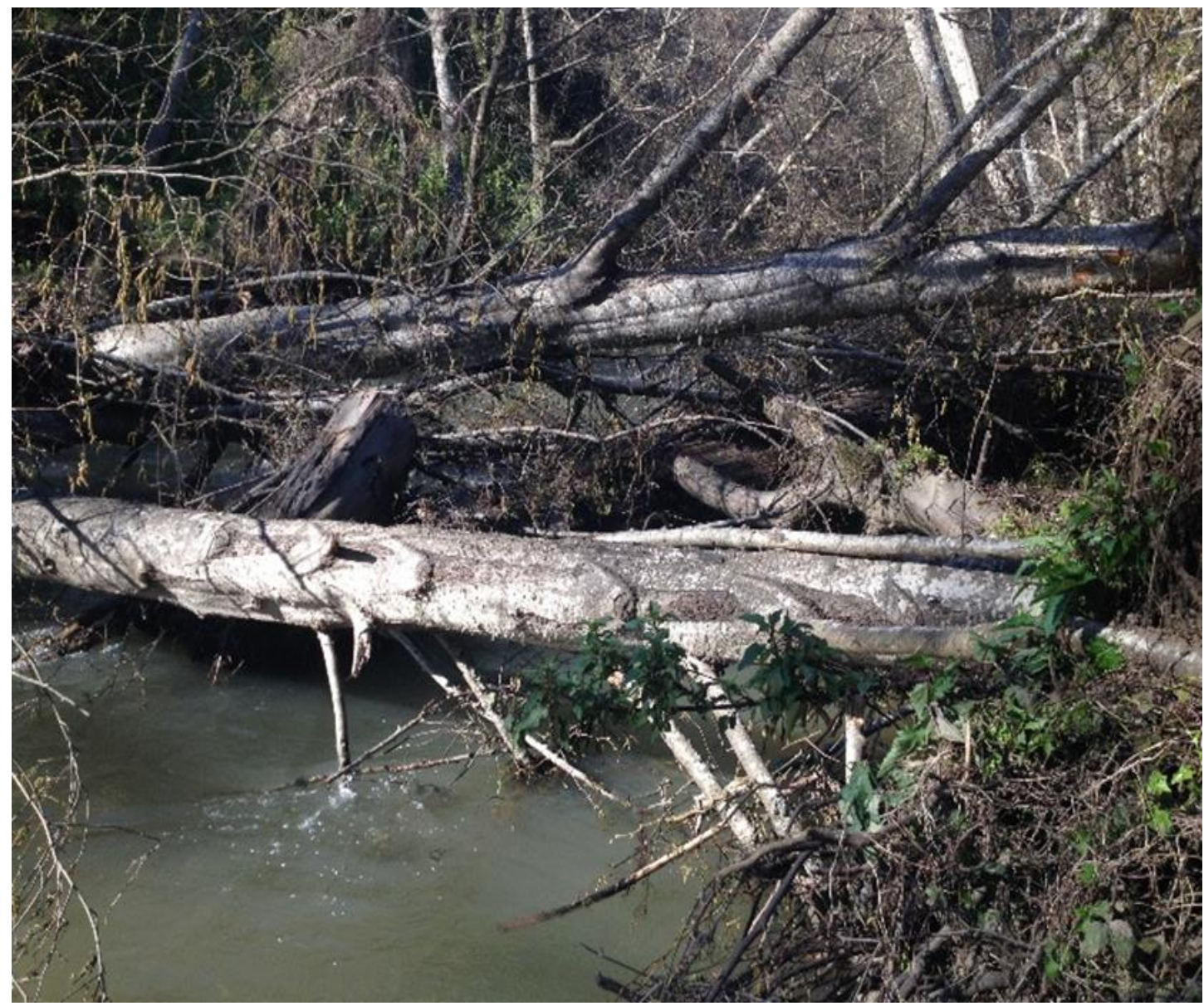

Figure 9. A view looking upstream at LWC 3 in phase II showing the multi-stemmed alder and LWC beneath. Most readily identifiable is the rootwad of LWC 3 in phase II on the left of the picture. 


\subsection{LCA Model Confidence}

This study was one of the first to apply LCA to the river restoration process. Therefore, it is difficult to compare the results of this study with others. Han et al., (2015) examined the impacts of several management scenarios in redwood forests. They documented that approximately $49 \%$ of global warming potential across these scenarios was associated with primary transportation. Primary transportation involved yarding logs from the stump to the landing and was the most time-consuming part of the timber harvesting processes they studied. If roughly half the impacts from the manual-ground based system in an un-even aged management scenario were from primary transportation, global warming impacts would be approximately $\approx 12,441 \mathrm{~kg} \mathrm{CO}_{2}$ eq per entry (entry is a term for a harvesting a timber stand).

In comparison to LSCR baseline scenarios, phase I emitted approximately $17,400 \mathrm{~kg} \mathrm{CO}_{2}$ eq. to restore 160 meters of stream, while phase II emitted approximately $12,000 \mathrm{~kg} \mathrm{CO}_{2}$ eq. to restore 125 meters of stream. Both primary transportation and river restoration use heavy machinery to transport and manipulate logs over rough terrain. There are additional interplays between the river restoration and timber harvest. Logging crews construct restoration projects because they have the machinery and skills to manipulate large materials such as trees and boulders (Cederholm et al., 1997).

Furthermore, primary transportation in a forest system may involve the operation of several logskidders, an excavator, or a front-end loader. Conducting SHI used similar equipment to primary transportation process. Therefore, it is reasonable to assume that the LSCR would emit less $\mathrm{CO}_{2}$ than would an entire logging operation. Logging operations tend to be large-scale and may take months to complete. Whereas, the LSCR took approximately three weeks for phase I and two weeks for phase II. 
Another study by Dias and Arroja (2012) documented the impacts associated with site preparation of eucalypt and maritime pine production in Portugal. Site preparation for the high intensity management sites, was responsible for emitting approximately three $\mathrm{kg} \mathrm{CO}_{2}$ eq. per $\mathrm{m}^{3}$ of roundwood. This is similar to the site preparation in phase I of the LSCR, which emitted approximately two $\mathrm{kg} \mathrm{CO}_{2}$ eq. per meter of stream restored. Both site preparation processes used small engine equipment, such as chainsaws and small tractors to clear and manipulate vegetation.

Another roundwood production study by González-García et al. (2014), attributed $5.6 \mathrm{~kg} \mathrm{CO}_{2}$ eq. per $\mathrm{m}^{3}$ of roundwood in the logging stage of a low-intensity pine wood scenario in Portugal. The logging stage referred to final cutting, forwarding, and loading onto trucks. A process which is similar to the site preparation in phase II of the LSCR, which emitted $6.2 \mathrm{~kg} \mathrm{CO}_{2}$ eq. per meter of stream restored. Both systems employed the use of small engine equipment and large equipment, such as chainsaws, hedge trimmers, pole saws, tractors, and mid-sized excavators.

Timber harvest and river restoration have distinctly different goals. However, both processes utilize similar equipment to transport heavy materials and clear land. Therefore, it is reasonable to expect that LCA studies on timber harvests would provide comparison points for LCA studies on river restoration. Despite similarities between the two processes, further LCA studies are needed to assess the full range of impacts from river restoration.

This study used Ecoinvent v. 3.3 data to report the final life cycle impact assessment results. In the process of developing this study, two secondary data sets were used. The impact results were initially computed using a combination of data from Ecoinvent v. 3.3 and from the National Renewable Energy Laboratory- U.S. Life Cycle Inventory Database. Data from the U.S. Life Cycle Inventory Database were initially used to specify the rate of fuel and lubricant use of each piece of equipment used in on-site construction. At this stage of study development, Ecoinvent data were used to model upstream impacts from transportation and raw material production. 
Despite using two data sources, initial life cycle impact results were similar to the final results reported in this study. Ultimately, Ecoinvent data were chosen for consistency and data quality. The similarity between the initial modeling results and current results suggest our findings are reasonable.

\subsection{Monitoring Requirements for the LCA Model}

This LCA study modeled the impacts from the transportation, construction, and raw material extraction phases of the LSCR. Table 8 outlines the tasks required to repeat the methodology used in this study to quantify the environmental performance of a river restoration project. We estimate that 563 person-hours would be required over the course of a year to model environmental impacts on the basis of geomorphic change. To assess the geomorphic change, a geomorphic effectiveness monitoring program was used. This program required a great deal of person hours and can be complex and expensive to set up and employ. Furthermore, to measure effectiveness using this method the field crew must survey prior to and approximately one year after installing structures to account for changes in the stream channel. This is necessary along most locations on the west coast of North America because of to the timing of the rainy season. The results of this study suggest that SHI projects should be exposed to at least one substantial flow event (close to bankful) to expect any significant change in channel morphology. Monitoring tasks become less onerous without effectiveness monitoring. We estimate that it would take approximately 255 person-hours to run a LCA on a typical SHI project. 
Table 8. An outline of tasks associated with LCA data collection, modeling, and incorporation with a geomorphic effectiveness monitoring program.

Data Collection

Task

Person Hours

Key Inputs

Suggestions

Gathering primary data on
during on-site
construction

Data mining for raw material production
20

Equipment operation hours, the model of equipment, types of equipment, and engine power

Type of material (material makeup), weights of material, haul distance (origin to site), and backhaul patterns

Material weight or size, type of material

40

Data mining for process that represent upstream processes
Spend time observing the installation of the project, speaking with equipment operators, ask operators to track hourly usage

Ask equipment operators to estimate weight or speak to managers at source gate

These data are relatively easy to gather based off of the transportation phase

Use generic diesel machinery unit processes to represent on-site construction, transportation processes

Use available upstream processing data

\section{LCA Model Building}

Task

Person Hours

Key Processes

Notes

\begin{tabular}{cccc}
$\begin{array}{c}\text { Constructing the LCA } \\
\text { Model }\end{array}$ & 20 & Building the LCA model on LCA software & $\begin{array}{c}\text { Most of the required processes were } \\
\text { available in Ecoinvent databases } \\
\text { Many studies focused on global } \\
\text { warming, acidification, }\end{array}$ \\
$\begin{array}{c}\text { Running models and } \\
\text { debugging }\end{array}$ & 20 & $\begin{array}{c}\text { Outputting results based on desired impact } \\
\text { assessment methodology and functional unit }\end{array}$ & $\begin{array}{c}\text { eutrophication, and photochemical } \\
\text { ozone formation }\end{array}$ \\
$\begin{array}{c}\text { Report writing and life } \\
\text { cycle interpretation }\end{array}$ & 120 & Writing, data entry, site description, etc. & Plan for adquate time for this phase \\
$\begin{array}{c}\text { Incorporating geomorphic } \\
\text { effectiveness monitoring } \\
\text { program }\end{array}$ & 308 & $\begin{array}{c}\text { Incorporating an ongoing geomorphic } \\
\text { monitoring program to recreate the 1\% TDI } \\
\text { change as functional unit }\end{array}$ & $\begin{array}{c}\text { Ensure that TDI percent increase is } \\
\text { accurate }\end{array}$ \\
\hline
\end{tabular}

Total 


\subsection{Data Requirements for TDI Effectiveness Monitoring}

Topographic surveys are a reliable way to monitor effectiveness of river restoration projects and have been employed in many studies (Tompkins and Kondolf, 2007; Koljonen et al., 2013; Carah et al., 2014; Poppe et al., 2016). However, collecting the topographic data required to run the TDI analysis was time consuming and required at least 8-12 months between pre- and post- project surveys (Table 9). Once the data were collected, the TDI was a straightforward way to quantify effectiveness of the LSCR and required about 28 person hours. Availability of these data would allow managers to calculate environmental performance much more quickly.

Roughly 600-1000 points needed to be shot to generate a point cloud large enough to capture subtle changes in a representative stream reach $(\approx 150$ meters $)$. This number depends on the complexity of the surface, as more shots are needed to represent more complex topography. Conversely, simpler or planar stream channels require less surveying time. Furthermore, a total station or similar survey equipment was required to collect the data. Total stations can cost over $\$ 10,000$ and generally require two people to operate, especially in dense riparian vegetation.

Also, setting control points can be expensive and time consuming, as it is wise to use a professional land surveyor to georeference a set of control points.

Ways to streamline survey data collection include: (1) adequately marking the study reach; (2) shooting approximately the same number of points for pre- and post-installation surveys; (3) placing control points so that they minimize the need to pick up; (4) maximize visibility by using total station functions to backsight off two points; and (5) setup in the stream channel if conditions allow. 
Table 9. An outline of tasks associated with establishing a geomorphic effectiveness monitoring program.

\begin{tabular}{|c|c|c|}
\hline \multicolumn{3}{|c|}{ Geomorphic Effectivness Monitoring } \\
\hline Task & Person Hours & Key Actions \\
\hline Setting Control Points & 80 & $\begin{array}{l}\text { Ensure georeferenced control points are permantly } \\
\text { monumented adjacent to restoration reach }\end{array}$ \\
\hline & & $\begin{array}{c}\text { Need a professional land surveyor or expert in } \\
\text { hydrology/surveying }\end{array}$ \\
\hline & & $\begin{array}{c}\text { Ensure control points are mapped, clearly labeled, and } \\
\text { visible. }\end{array}$ \\
\hline & & $\begin{array}{l}\text { Ensure that extra control points are set in case of } \\
\text { movement (usually 10-12 per } 200 \text { meters of stream) }\end{array}$ \\
\hline Total Station Survey & 200 & $\begin{array}{c}\text { Using a total station to shooting approximaltey } 2000 \\
\text { survey points for a before/after restoration survey- } \\
\text { generally requires two people }\end{array}$ \\
\hline & & Shoot breaklines at thalweg, bottom bank, and top bank. \\
\hline & & $\begin{array}{c}\text { Shoot generally topographic survey over the channel and } \\
\text { off-channel features }\end{array}$ \\
\hline & & Shoot in LWC components \\
\hline Creating DEM and Raster & 16 & Generating DEM in GIS or CAD \\
\hline Classification & 4 & Running 1 foot classificaiton in GIS \\
\hline Quantifiying TDI & 4 & Using TDI equation to quantify changes \\
\hline Integrating into LCA & 4 & Integrating results into the LCA software \\
\hline
\end{tabular}




\section{Conclusion}

\subsection{Addressing the Key Research Questions}

This study was the first to quantify the environmental performance of a river restoration project. The results suggest that SHI projects can generate substantial environmental impacts, on a scale comparable to certain aspects of forestry operations. The SHI impacts were most strongly associated with installing wood features. In both phase I and II, installing wood features accounted the majority $(<50 \%)$ of the contributions to each impact category. These impacts were most strongly associated with upstream processes in raw material production and heavy machinery operation during on-site construction. This study also quantified TDI change, which gave insights into the functionality of each phase. Coupling the LCA results with TDI changes allowed the author to quantify the environmental performance of phases I and II of the LSCR and gain a better understanding of the costs and benefits of SHI.

\subsection{Recommendations for Managers}

This research demonstrates that SHI projects can generate significant environmental impacts. Considering this finding, managers may want to consider ways they could reduce the impacts of SHI projects. This section outlines four major techniques that may better the environmental performance of SHI. Three of which may directly reduce life cycle impacts and one of which may enhance favorable changes in TDI.

\subsubsection{Accelerated Recruitment Method}

The accelerated recruitment method may be applicable to many SHI projects. It has the capacity to reliably improve habitat, increase the speed and scale of SHI project installations, and is more cost-effective than importing materials (Carah et al., 2014). Although accelerated recruitment was used in the LSCR, greater use of this method may have decreased impacts substantially (Figure 6). Additionally, the effectiveness monitoring portion of this study showed promising results 
when large pieces of wood were recruited from the streambank (Figure 7). If the opportunity presents itself, managers should consider using the accelerated recruitment technique. It is likely that this technique would increase the environmental performance of a SHI project, especially if this technique were used to introduce larger key pieces to the channel.

\subsubsection{Plant Sourcing}

A surprising result of this study is that using nursery grown plants generate lower impacts than those of the baseline scenario (Figure 6), which used a backhoe to harvest most plants. Nursery sourcing lowered cumulative environmental impacts by $10 \%$ in phase I and $11 \%$ in phase II. This result is subject to change depending on the nursery process and plant haul distance. Managers may opt to use plants sourced from a nearby nursery, especially if local plant harvesting requires heavy equipment use.

\subsubsection{Fuels Combustion}

Heavy equipment operation and associated upstream fuel production was a hotspot in this study and many others. It is crucial that a manger seeks to minimize operation time, for which some suggestions are: (1) to ensure easy and clear access to the channel and streambank, (2) to use small engine equipment to clear access corridors during site preparation, (3) to run more fuelefficient machinery or use biofuel-powered machinery, and (4) to source materials from nearby to minimize transportation distance.

\subsubsection{Franken-log Design}

If developing pool habitat or improving topographic diversity are goals of a SHI project, managers may want to consider incorporating a "franken-log design". A "franken-log" was a ballasted LWC with a rootward attached to downstream end of the log. In both phases I and II, the structures that created the most scour were all "franken-logs". "Franken-logs" have the 
potential to improve habitat by initiating pool development and by increasing overall complexity. Therefore, this design warrants further experimentation and research.

\subsection{Study Conclusions}

\subsubsection{LCA Monitoring Applicability}

The LCA methodology employed in this study follows an internationally standardized framework (ISO, 2006). This framework helps to provide a repeatable protocol for conducting LCA studies on SHI and other river restoration projects. This study suggests that if the appropriate primary data are collected during on-site construction, then quantifying the environmental impacts of SHI is relatively straightforward and quick. The key challenge for this study was approximating the time spent on each piece of equipment and some other crucial measurements such as material weights. These data were approximated by the author and the project manager months after the LSCR was installed. Fortunately, the author and project manager were on-site during construction and were able to back out many of these data. To minimize these data collection challenges, practitioners should keep detailed notes on the LCI inputs outlined in Tables 1,2, and 3 (sample data form provided, see appendix, Table A5). Furthermore, managers should carefully note what efforts are assigned to a given aspect of a restoration project. Ideally, addressing these key challenges will make LCA a valuable tool in monitoring SHI and river restoration projects. Repeating this methodology is crucial to verifying the results reported in this study.

\subsubsection{Functional Unit Applicability}

The TDI effectiveness monitoring in our study was developed as a novel way to quantify the benefits of the SHI process. TDI percent change was incorporated into our study as a functional unit, which was used to scale the baseline LCA results. TDI adapted topographic survey data to quantify the complexity of a stream channel and provide a functional unit for the LCA study. The key challenge to TDI effectiveness was establishing and conducting the total station survey. To 
set up the total station survey a professional land surveyor checked benchmark locations and helped to setup the first survey control points. Once the first control points were set, a lot of effort went into setting and maintaining control points along the restoration reaches. Once the second set of control points were set, the survey took approximately 200 person-hours and a year to complete. If these data are already available, then they can be readily processed to quantify TDI. If topographic survey data were not available, a manager might consider using a length-based reference unit to scale environmental impacts. The length-based reference unit gave valuable insights but did not reflect the actual function of SHI. Given the available data, TDI was the best way to quantify the benefits of the LSCR. However, more research is needed to understand if TDI can reliably quantify the complexity of a stream channel.

\subsection{Future Research}

There are two ideal case studies to apply this methodology. One of which is phase III of the LSCR which was implemented in summer of 2017. Phase III of the LSCR used techniques that this study attempted to represent in the AS 50\%. Phase III used less imported materials and the accelerated recruitment method more frequently. Evaluating the environmental performance of phase III would give managers a better idea of the range of impacts which could be expected from SHI projects.

The second case-study opportunity was a SHI project on San Vicente Creek. San Vicente Creek is near Scotts Creek and supports Coho and steelhead. In summer of 2017 a SHI project was installed using the directional falling of trees into the stream channel. The San Vicente Creek SHI project used techniques that this study attempted to represent in the AS $100 \%$. Using this methodology to evaluate projects on Scotts Creek and San Vicente Creek will provide insight on how the accelerated recruitment method can influence TDI and how this affects the overall environmental performance of SHI. 


\section{References}

Association of Environmental Professionals. 2010. California Environmental Quality Act Statute and Guidelines.

Barandica, J.M., G. Fernandez-Sanchez, A. Berzosa, J.A. Delgado, and F.J. Acosta. 2013. Applying life cycle thinking to reduce greenhouse gas emissions from road projects. J. Clean. Prod. 57: 79-91.

Bare, J. 2011. TRACI 2.0: The tool for the reduction and assessment of chemical and other environmental impacts 2.0. Clean Technol. Environ. Policy 13(5): 687-696.

Bernhardt, E.S., M.A. Palmer, J.D. Allan, G. Alexander, K. Barnas, S. Brooks, J. Carr, S. Clayton, C. Dahm, J. Follstad-Shah, D. Galat, S. Gloss, P. Goodwin, D. Hart, B. Hassett, R. Jenkinson, S. Katz, G.M. Kondolf, P.S. Lake, R. Lave, J.L. Meyer, T.K. O’Donnell, L. Pagano, B. Powell, and E. Sudduth. 2005. Synthesizing U.S. River Restoration Efforts. Science (80-308) (5722).

Cambria, D., and D. Pierangeli. 2012. Application of a life cycle assessment to walnut tree (Juglans regia L.) high quality wood production: a case study in southern Italy. J. Clean. Prod. 23(1): 37-46

Carah, J.K., C.C. Blencowe, D.W. Wright, and L. a Bolton. 2014. Low-Cost Restoration Techniques for Rapidly Increasing Wood Cover in Coastal Coho Salmon Streams. North Am. J. Fish. Manag. 34(May): 1003-1013

Cederholm, C.J., R.E. Bllby, P.A. Bisson, T.W. Bumstead, B.R. Fransen, W.J. Scarlett, and J.W. Ward. 1997. Response of Juvenile Coho Salmon and Steelhead to Placement of Large Woody Debris in a Coastal Washington Stream. North Am. J. Fisheries Manag. 17: 947963.

Cook, B.O. 2016. Lower Scotts Creek Floodplain and Habitat Enhancement Project. Master's Theses Proj. Reports

Dias, A.C., and L. Arroja. 2012. Environmental impacts of eucalypt and maritime pine wood production in Portugal. J. Clean. Prod. 37: 368-376.

Flosi, G., S. Downie, J. Hopelain, M. Bird, R. Coey, and B. Collins. 2010. California Salmonid Stream Habitat Restoration Manual, 4th Edition. 1(4): 525

Fullerton, A.H., D. Jensen, E.A. Steel, D. Miller, and P. Mcelhany. 2010. How Certain Are Salmon Recovery Forecasts? A Watershed-scale Sensitivity Analysis. Environ. Model Assess. 15: 13-26

Gallagher, S., S. Thompson, and D. Wright. 2012. Identifying factors limiting Coho salmon to inform stream restoration in coastal Northern California. Calif. Fish Game 98(4): 185-201

Gan, V.J.L., J.C.P. Cheng, and I.M.C. Lo. 2016b. Integrating life cycle assessment and multiobjective optimization for economical and environmentally sustainable supply of aggregate. J. Clean. Prod. 113: 76-85

Gerhard, M., and M. Reich. 2000. Restoration of streams with large wood: Effects of accumulated and built-in wood on channel morphology, habitat diversity and aquatic fauna. Int. Rev. Hydrobiol. 85(1): 123-137. 
González-García, S., V. Bonnesoeur, A. Pizzi, G. Feijoo, and M.T. Moreira. 2014a. Comparing environmental impacts of different forest management scenarios for maritime pine biomass production in France. J. Clean. Prod. 64: 356-367

González-García, S., A.C. Dias, G. Feijoo, M.T. Moreira, and L. Arroja. 2014b. Divergences on the environmental impact associated to the production of maritime pine wood in Europe: French and Portuguese case studies. Sci. Total Environ. 472: 324-337

González-García, S., I. Krowas, G. Becker, G. Feijoo, and M.T. Moreira. 2013a. Cradle-to-gate life cycle inventory and environmental performance of Douglas-fir roundwood production in Germany. J. Clean. Prod. 54: 244-252

González-García, S., B. Mola-Yudego, I. Dimitriou, P. Aronsson, and R. Murphy. 2012. Environmental assessment of energy production based on long term commercial willow plantations in Sweden. Sci. Total Environ. 421-422: 210-219

González-García, S., B. Mola-Yudego, and R.J. Murphy. 2013b. Life cycle assessment of potential energy uses for short rotation willow biomass in Sweden. Int. J. Life Cycle Assess. 18(4): 783-795.

Gerhard, M., and M. Reich. 2000. Restoration of streams with large wood: Effects of accumulated and built-in wood on channel morphology, habitat diversity and aquatic fauna. Int. Rev. Hydrobiol. 85(1): 123-137.

Hafs, A.W., L.R. Harrison, R.M. Utz, and T. Dunne. 2014. Quantifying the role of woody debris in providing bioenergetically favorable habitat for juvenile salmon. Ecol. Modell. 285: 30 38.

Han, H.-S., E. Oneil, R.D. Bergman, I.L. Eastin, and L.R. Johnson. 2015. Cradle-to-gate life cycle impacts of redwood forest resource harvesting in northern California. J. Clean. Prod. 99: $217-229$

Handler, R.M., D.R. Shonnard, P. Lautala, D. Abbas, and A. Srivastava. 2014. Environmental impacts of roundwood supply chain options in Michigan: life-cycle assessment of harvest and transport stages. J. Clean. Prod. 76: 64-73

Hilderbrand, R.H., A.D. Lemly, C.A. Dolloff, and K.L. Harpster. 1998. Design considerations for large woody debris placement in stream ehancement projects. North Am. J. Fish. Manag. 18(November): 161-167.

Hillard, A.B. 2015. Detecting Change in Central California Coast Coho Salmon Habitat in Scotts Creek, California, from 1997-2013. (April)

Howson, T.J., B.J. Robson, T.G. Matthews, and B.D. Mitchell. 2012. Size and quantity of woody debris affects fish assemblages in a sediment-disturbed lowland river. Ecol. Eng. 40: 144152

ISO. 2006. Environmental management — Life cycle assessment — Principles and framework. Int. Stand. Organ. 2006: 1-28

Jong, M., and I.G. Cowx. 2016. Long-term response of salmonid populations to habitat restoration in a boreal forest stream. Ecol. Eng.

Kail, J., D. Hering, S. Muhar, M. Gerhard, and S. Preis. 2007. The use of large wood in stream restoration: Experiences from 50 projects in Germany and Austria. J. Appl. Ecol. 44(6): $1145-1155$.

Katz, S.L., K. Barnas, R. Hicks, J. Cowen, and R. Jenkinson. 2007. Freshwater habitat restoration 
actions in the Pacific Northwest: A decade's investment in habitat improvement. Restor. Ecol

Kauffman, J.B., R.L. Beschta, N. Otting, and D. Lytjen. 2011. An ecological perspective of riparian and stream restoration in the western United States. Fisheries 22(5): 12-24.

Kayo, C., R. Noda, T. Sasaki, and S. Takaoku. 2014. Carbon balance in the life cycle of wood: targeting a timber check dam. J. Wood Sci. 61(1): 70-80.

Koljonen, S., A. Huusko, A. Mäki-Petäys, P. Louhi, and T. Muotka. 2013. Assessing habitat suitability for juvenile atlantic salmon in relation to in-stream restoration and discharge variability. Restor. Ecol. 21(3): 344-352.

Kristensen, E.A., A. Baattrup-Pedersen, and H. Thodsen. 2011. An evaluation of restoration practises in lowland streams: Has the physical integrity been re-created? Ecol. Eng

Liu, C., C.R. Ahn, A.M. Asce, X. An, and S. Lee. 2013. Life-Cycle Assessment of Concrete Dam Construction: Comparison of Environmental Impact of Rock-Filled and Conventional Concrete.

López Gayarre, F., J. González Pérez, C. López-Colina Pérez, M. Serrano López, and A. López Martínez. 2015. Life cycle assessment for concrete kerbs manufactured with recycled aggregates. J. Clean. Prod. 113

Morandi, B., H. Piégay, N. Lamouroux, and L. Vaudor. 2014. How is success or failure in river restoration projects evaluated? Feedback from French restoration projects. J. Environ. Manage. 137: 178-188.

Muotka, T., R. Paavola, A. Haapala, M. Novikmec, and P. Laasonen. 2002. Long-term recovery of stream habitat structure and benthic invertebrate communities from in-stream restoration. Biol. Conserv.

Nagayama, S., and F. Nakamura. 2010. Fish habitat rehabilitation using wood in the world. Landsc. Ecol. Eng. 6(2): 289-305.

National Marine Fisheries Service. 2012. Final recovery plan for central California coast Coho salmon Evolutionarily Significant Unit. Natl. Mar. Fish. Serv. Southwest Reg. St. Rosa, Calif.

Nehlsen, W., J.E. Williams, and J.A. Lichatowich. 1991. Pacific Salmon at the Crossroads: Stocks at Risk from California, Oregon, Idaho, and Washington. Fisheries 16(2).

O’Neal, J., P. Roni, B. Crawford, A. Ritchie, and A. Shelly. 2016. Comparing Stream Restoration Project Effectiveness Using a Programmatic Evaluation of Salmonid Habitat and Fish Response. North Am. J. Fish. Manag. 36(November): 681-703.

Palmer, M., J.D. Allan, J. Meyer, and E.S. Bernhardt. 2007. River restoration in the twenty-first century: Data and experiential knowledge to inform future efforts. Restor. Ecol.

Pilotto, F., G.L. Harvey, G. Wharton, and M.T. Pusch. 2016. Simple large wood structures promote hydromorphological heterogeneity and benthic macroinvertebrate diversity in lowgradient rivers. Aquat. Sci. 78(4): 755-766.

Poppe, M., J. Kail, J. Aroviita, M. Stelmaszczyk, M. Giełczewski, and S. Muhar. 2016. Assessing restoration effects on hydromorphology in European mid-sized rivers by key hydromorphological parameters. Hydrobiologia 769(1). 
Rocco, M. V., G. Cassetti, F. Gardumi, and E. Colombo. 2015. Exergy Life Cycle Assessment of soil erosion remediation technologies: an Italian case study. J. Clean. Prod. 112: 3007-3017

Roni, P., T.J. Beechie, R.E. Bilby, F.E. Leonetti, M.M. Pollock, and G.R. Pess. 2002. A Review of Stream Restoration Techniques and a Hierarchical Strategy for Prioritizing Restoration in Pacific Northwest Watersheds. North Am. J. Fish. Manag. 22(1): 1-20.

Roni, P., T. Beechie, G.R. Pess, and K. Hanson. 2014. Wood placemment in river restoration: Fact, fiction and future direction. Can. J. Fish. Aquat. Sci. 478(206): 10.1139

Roni, P., K. Hanson, and T. Beechie. 2008. Global Review of the Physical and Biological Effectiveness of Stream Habitat Rehabilitation Techniques. North Am. J. Fishenel Manag. 28: 856-890.

Roni, P., G. Pess, T. Beechie, and S. Morley. 2010. Estimating Changes in Coho Salmon and Steelhead Abundance from Watershed Restoration: How Much Restoration is Needed to Measurably Increase Smolt Production? North Am. J. Fish. Manag. 30(6): 1469-1484.

Rosenfeld, J.S., and L. Huato. 2003. Relationship between Large Woody Debris Characteristics and Pool Formation in Small Coastal British Columbia Streams. North Am. J. Fish. Manag. 23(3): 928-938

Rumps, J.M., S.L. Katz, K. Barnas, M.D. Morehead, R. Jenkinson, S.R. Clayton, and P. Goodwin. 2007. Stream Restoration in the Pacific Northwest: Analysis of Interviews with Project Managers. Restor. Ecol. 15(3): 506-515

Saud, P., J. Wang, W. Lin, B. Sharma, and D. Hartley. 2013. A life cycle analysis of forest carbon balance and carbon emissions of timber harvesting in West Virginia. Wood Fiber Sci

Scotts, L., C. Salmonid, H. Improvement, J. Mckenna, B. President, A. Moss, G. Manager, P. Agency, I. Tribe, and S.L. Obispo. 2014. FRGP F \& D 2014 Proposal Application Form Section 1 : Summary Information Section 2 : Location Information.

Solazzi, M.F., T.E. Nickelson, S.L. Johnson, and J.D. Rodgers. 2000. Effects of increasing winter rearing habitat on abundance of salmonids in two coastal Oregon streams. Can. J. Fish. Aquat. Sci 57: 906-914.

Stewart, G.B., H.R. Bayliss, D.A. Showler, W.J. Sutherland, A.S. Pullin, and A.S. Pullin1 '. 2009. Effectiveness of Engineered In-Stream Structure Mitigation Measures to Increase Salmonid Abundance: A Systematic Review. Source Ecol. Appl. Ecol. Appl. 19(194): 931941

Stripple, H. 2001. Life cycle assessment of Road. Swedish Environ. Res. Inst. IVL,(March 2001) 29(4): 414-22

Suwanit, W., and S.H. Gheewala. 2011. Life cycle assessment of mini-hydropower plants in Thailand. Int. J. Life Cycle Assess. 16(9): 849-858.

Swamp. 2015. The Perennial Streams Assessment (PSA): An Assessment of Biological Condition using the new California Stream Condition Index (CSCI).

Thompson, D.M. 2006. Did the pre-1980 use of in-stream structures improve streams? A reanalysis of historical data. Ecol. Appl.

Thompson, D.M., and G.N. Stull. 2002. The Development and Historic Use of Habitat Structures in Channel Restoration in the United States: The Grand Experiment in Fisheries Management. Géographie Phys. Quat. 56(1): 45 
Tompkins, M.R., and G.M. Kondolf. 2007. Systematic Postproject Appraisals to Maximize Lessons Learned from River Restoration Projects: Case Study of Compound Channel Restoration Projects in Northern California. Restor. Ecol. 15(3): 524-537.

Turney, D., and V. Fthenakis. 2011. Environmental impacts from the installation and operation of large-scale solar power plants. Renew. Sustain. Energy Rev. 15(6): 3261-3270.

Varun, R. Prakash, and I.K. Bhat. 2012. Life cycle greenhouse gas emissions estimation for small hydropower schemes in India. Energy 44(1): 498-508

Wernet, G., Bauer, C., Steubing, B., Reinhard, J., Moreno-Ruiz, E., and Weidema, B. 2016. The ecoinvent database version 3 (part I): overview and methodology. Int. J. Life Cycle Assess. 21(9): 1218-1230.

Whiteway, S.L., P.M. Biron, A. Zimmermann, O. Venter, and J.W.A. Grant. 2010. Do in-stream restoration structures enhance salmonid abundance? A meta-analysis. Can. J. Fish. Aquat. Sci. 67: 831-841.

Zhang, S., B. Pang, and Z. Zhang. 2014. Carbon footprint analysis of two different types of hydropower schemes: comparing earth-rockfill dams and concrete gravity dams using hybrid life cycle assessment. J. Clean. Prod. 103: 854-862 


\section{APPENDIX}

Table A1. Summary of selected LCA studies.

\begin{tabular}{|c|c|c|c|c|c|c|c|c|c|}
\hline Source & Field & Study Subject & Functional Unit & System Boundaries & Scenario & $\begin{array}{l}\text { Photochemical } \\
\text { Ozone Formation }\end{array}$ & Acidification & Global Warming & Eutrophication \\
\hline \multirow{4}{*}{$\begin{array}{c}\text { Barandica et al., } \\
2013\end{array}$} & \multirow{4}{*}{$\begin{array}{l}\text { Road } \\
\text { Projects }\end{array}$} & \multirow{4}{*}{$\begin{array}{l}\text { Examining the impacts } \\
\text { of constructing roads }\end{array}$} & \multirow{4}{*}{$1 \mathrm{~km}$ of road } & \multirow{4}{*}{$\begin{array}{l}\text { Materials production, site } \\
\text { preparation, construction, } \\
\text { operation, maintenance, and } \\
\text { disposal }\end{array}$} & Road Project 1 & - & - & $15200 \mathrm{tCO}_{2} \mathrm{e}$ & - \\
\hline & & & & & Road Project 2 & - & - & 50300 tCO2e & - \\
\hline & & & & & Road Project 3 & - & - & $41000 \mathrm{tCO} 2 \mathrm{e}$ & - \\
\hline & & & & & Road Project 4 & - & - & 8860 tCO2e & - \\
\hline $\begin{array}{c}\text { Cambria and } \\
\text { Pierangeli, } 2012\end{array}$ & Forestry & $\begin{array}{l}\text { Studying the impact of } \\
\text { walnut production in } \\
\text { Italy }\end{array}$ & $\begin{array}{l}\text { One } \mathrm{m}^{3} \text { of dry solid } \\
\text { wood under bark- } \\
\text { Walnut }\end{array}$ & $\begin{array}{l}\text { Background process, plantation } \\
\text { activities, silvicultural/log } \\
\text { transport }\end{array}$ & & $130 \mathrm{~g} \mathrm{C}_{2} \mathrm{H}_{4}$ eq & $770 \mathrm{~g} \mathrm{SO}_{2} \mathrm{eq}$ & $110 \mathrm{~kg} \mathrm{CO}_{2}$ eq & $582 \mathrm{~g} \mathrm{PO}_{4}^{-3} \mathrm{eq}$ \\
\hline \multirow[t]{9}{*}{$\begin{array}{c}\text { Dias and Arroja, } \\
2012\end{array}$} & \multirow[t]{9}{*}{ Forestry } & \multirow{9}{*}{$\begin{array}{l}\text { Examining the impacts } \\
\text { of forestry operations } \\
\text { in eucalyptus and } \\
\text { maritime pine } \\
\text { production in Portugal }\end{array}$} & \multirow[t]{9}{*}{$\begin{array}{l}\text { One } \mathrm{m}^{3} \text { of fresh } \\
\text { round wood under } \\
\text { bark }\end{array}$} & \multirow[t]{9}{*}{$\begin{array}{l}\text { Infrastructure establishment, site } \\
\text { preparation, stand establishment, } \\
\text { stand tending, and logging }\end{array}$} & $\begin{array}{l}\text { High Intensity Eucalypt- } \\
\text { Best Mgmt. Practices }\end{array}$ & $0.0031 \mathrm{~kg} \mathrm{C} 2 \mathrm{H} 4 \mathrm{eq}$ & $0.23 \mathrm{~kg} \mathrm{SO} 2 \mathrm{eq}$ & $18.5 \mathrm{~kg} \mathrm{CO} 2 \mathrm{eq}$ & $0.17 \mathrm{~kg} \mathrm{PO} 4 \mathrm{eq}$ \\
\hline & & & & & High Intensity Eucalypt & $0.0074 \mathrm{~kg} \mathrm{C} 2 \mathrm{H} 4 \mathrm{eq}$ & $0.22 \mathrm{~kg} \mathrm{SO} 2 \mathrm{eq}$ & $16.9 \mathrm{~kg} \mathrm{CO} 2 \mathrm{eq}$ & $0.16 \mathrm{~kg} \mathrm{PO} 4 \mathrm{eq}$ \\
\hline & & & & & Low Intensity Eucalypt & $0.0058 \mathrm{~kg} \mathrm{C} 2 \mathrm{H} 4 \mathrm{eq}$ & $0.05 \mathrm{~kg} \mathrm{SO} 2 \mathrm{eq}$ & $8.3 \mathrm{~kg} \mathrm{CO} 2 \mathrm{eq}$ & $0.02 \mathrm{~kg} \mathrm{PO} 4 \mathrm{eq}$ \\
\hline & & & & & High Intensity Maritime & & & & \\
\hline & & & & & $\begin{array}{l}\text { Pine- Best Mgmt. } \\
\text { Practices }\end{array}$ & $0.0021 \mathrm{~kg} \mathrm{CsH} 4 \mathrm{eq}$ & $0.08 \mathrm{~kg} \mathrm{SO} 2 \mathrm{eq}$ & $12.2 \mathrm{~kg} \mathrm{CO} 2 \mathrm{eq}$ & $0.03 \mathrm{~kg}$ PO4 eq \\
\hline & & & & & High Intensity Maritime & & & & \\
\hline & & & & & Pine & $0.0048 \mathrm{~kg} \mathrm{C} 2 \mathrm{H} 4 \mathrm{eq}$ & $0.07 \mathrm{~kg} \mathrm{SO} 2 \mathrm{eq}$ & $11.2 \mathrm{~kg} \mathrm{CO} 2 \mathrm{eq}$ & $0.03 \mathrm{~kg} \mathrm{PO} 4 \mathrm{eq}$ \\
\hline & & & & & Low Intensity Maritime & & & & \\
\hline & & & & & Pine & $0.0036 \mathrm{~kg} \mathrm{C} 2 \mathrm{H} 4 \mathrm{eq}$ & $0.03 \mathrm{~kg} \mathrm{SO} 2 \mathrm{eq}$ & $4.8 \mathrm{~kg} \mathrm{CO} 2 \mathrm{eq}$ & $0.01 \mathrm{~kg} \mathrm{PO} 4 \mathrm{eq}$ \\
\hline \multirow[t]{2}{*}{$\begin{array}{l}\text { Gonzalez-Garcia } \\
\text { et al., 2014a }\end{array}$} & \multirow[t]{2}{*}{ Forestry } & \multirow{2}{*}{$\begin{array}{l}\text { Comparing forest } \\
\text { management scenarios } \\
\text { in France }\end{array}$} & \multirow{2}{*}{$\begin{array}{l}\text { One } \mathrm{m} 3 \text { of fresh } \\
\text { round wood under } \\
\text { bark }\end{array}$} & \multirow[t]{2}{*}{$\begin{array}{l}\text { Site preparation, stand } \\
\text { establishment, logging }\end{array}$} & $\begin{array}{l}\text { Extensive Management } \\
\text { Scenario } \\
\text { Intensive Management }\end{array}$ & $0.0044 \mathrm{~kg} \mathrm{C} 2 \mathrm{H} 4 \mathrm{eq}$ & $0.099 \mathrm{~kg} \mathrm{SO} 2 \mathrm{eq}$ & $16.7 \mathrm{~kg} \mathrm{CO} 2 \mathrm{eq}$ & $0.029 \mathrm{~kg} \mathrm{PO} 4 \mathrm{eq}$ \\
\hline & & & & & Scenario & $0.0037 \mathrm{~kg} \mathrm{C} 2 \mathrm{H} 4 \mathrm{eq}$ & $0.104 \mathrm{~kg} \mathrm{SO} 2 \mathrm{eq}$ & $16 \mathrm{~kg} \mathrm{CO} 2 \mathrm{eq}$ & $0.039 \mathrm{~kg}$ PO4 eq \\
\hline
\end{tabular}


Table A1 cont.

\begin{tabular}{|c|c|c|c|c|c|c|c|c|c|}
\hline Source & Field & Study Subject & Functional Unit & System Boundaries & Scenario & $\begin{array}{c}\text { Photochemical } \\
\text { Ozone Formation }\end{array}$ & Acidification & Global Warming & Eutrophication \\
\hline \multirow[t]{4}{*}{$\begin{array}{l}\text { Gonzalez-Garcia } \\
\text { et al., 2014b }\end{array}$} & \multirow[t]{4}{*}{ Forestry } & \multirow{4}{*}{$\begin{array}{l}\text { Comparing French and } \\
\text { Portuguese case } \\
\text { studies }\end{array}$} & \multirow{4}{*}{$\begin{array}{l}\text { One } \mathrm{m} 3 \text { of fresh } \\
\text { round wood under } \\
\text { bark }\end{array}$} & \multirow[t]{4}{*}{$\begin{array}{l}\text { Site preparation, stand } \\
\text { establishment, logging }\end{array}$} & $\begin{array}{l}\text { Intensive Management - } \\
\text { France }\end{array}$ & $0.19 \mathrm{~kg}$ NMVOC eq & $0.12 \mathrm{~kg} \mathrm{SO} 2 \mathrm{eq}$ & $18.9 \mathrm{~kg} \mathrm{CO} 2 \mathrm{eq}$ & $0.22 \mathrm{~kg} 1,4-\mathrm{DCB}$ eq \\
\hline & & & & & $\begin{array}{l}\text { Extensive Management- } \\
\text { France }\end{array}$ & $0.28 \mathrm{~kg}$ NMVOC eq & $0.17 \mathrm{~kg} \mathrm{SO} 2 \mathrm{eq}$ & $27.3 \mathrm{~kg} \mathrm{CO} 2 \mathrm{eq}$ & $0.33 \mathrm{~kg} 1,4-\mathrm{DCB}$ eq \\
\hline & & & & & & $0.09 \mathrm{~kg}$ NMVOC eq & $0.04 \mathrm{~kg} \mathrm{SO} 2 \mathrm{eq}$ & $5.6 \mathrm{~kg} \mathrm{CO} 2 \mathrm{eq}$ & $0.04 \mathrm{~kg}$ 1,4-DCB eq \\
\hline & & & & & $\begin{array}{c}\text { High Intensive } \\
\text { Management- Portugal }\end{array}$ & $0.24 \mathrm{~kg}$ NMVOC eq & $0.15 \mathrm{~kg} \mathrm{SO} 2 \mathrm{eq}$ & $21.8 \mathrm{~kg} \mathrm{CO} 2 \mathrm{eq}$ & $0.32 \mathrm{~kg} \mathrm{1,4-DCB} \mathrm{eq}$ \\
\hline $\begin{array}{l}\text { Gonzalez-Garcia } \\
\text { et al., 2013a }\end{array}$ & Forestry & $\begin{array}{l}\text { Studying the impacts } \\
\text { of Douglas-fir } \\
\text { production in } \\
\text { Germany }\end{array}$ & $\begin{array}{c}\text { One } \mathrm{m} 3 \text { of fresh } \\
\text { round wood under } \\
\text { bark }\end{array}$ & $\begin{array}{l}\text { Site preparation, stand } \\
\text { establishment, logging }\end{array}$ & $\begin{array}{l}\text { German Douglas-fir } \\
\text { forest plantation }\end{array}$ & $24.91 \mathrm{~kg}$ NMVOC eq & $14.65 \mathrm{~kg} \mathrm{SO} 2 \mathrm{eq}$ & $2.35 \mathrm{~kg} \mathrm{CO} 2 \mathrm{eq}$ & $7.15 \mathrm{~kg} \mathrm{~N} \mathrm{eq}$ \\
\hline \multirow{2}{*}{$\begin{array}{l}\text { Gonzalez-Garcia } \\
\text { et al., } 2012\end{array}$} & \multirow{2}{*}{ Forestry } & $\begin{array}{l}\text { Assessment of energy } \\
\text { production in long- }\end{array}$ & \multirow{2}{*}{$\begin{array}{l}1 \text { hectare of } \\
\text { cultivated area }\end{array}$} & \multirow{2}{*}{$\begin{array}{l}\text { Establishment, cutting, and } \\
\text { restoration/replacement }\end{array}$} & Non-fertilized scenario & $0.52 \mathrm{~kg} \mathrm{C} 2 \mathrm{H} 4 \mathrm{eq}$ & $20.9 \mathrm{~kg} \mathrm{SO} 2 \mathrm{eq}$ & $-207010 \mathrm{~kg} \mathrm{CO} 2 \mathrm{eq}$ & $5.9 \mathrm{~kg} \mathrm{PO} 4 \mathrm{eq}$ \\
\hline & & $\begin{array}{c}\text { willow plantations in } \\
\text { Sweden }\end{array}$ & & & Fertilized scenario & $1.2 \mathrm{~kg} \mathrm{C} 2 \mathrm{H} 4 \mathrm{eq}$ & $73.3 \mathrm{~kg} \mathrm{SO} 2 \mathrm{eq}$ & $-323702 \mathrm{~kg} \mathrm{CO} 2 \mathrm{eq}$ & $159.5 \mathrm{~kg}$ PO4 eq \\
\hline \multirow{4}{*}{$\begin{array}{l}\text { Gonzalez-Garcia } \\
\text { et al., 2013b }\end{array}$} & \multirow{4}{*}{ Forestry } & Assesses of potential & \multirow{4}{*}{$\begin{array}{l}1 \mathrm{~km} \text { distance- } \\
\text { drive } / 1 \mathrm{MJ} \text { of heat } \\
\text { released }\end{array}$} & \multirow{4}{*}{$\begin{array}{l}\text { Establishment, cutting, and } \\
\text { restoration, energy plants, } \\
\text { ethanol/gasoline production } \\
\text { systems }\end{array}$} & Ethanol use in vehicle & $0.153 \mathrm{~kg} \mathrm{C} 2 \mathrm{H} 4 \mathrm{eq}$ & $0.806 \mathrm{~kg} \mathrm{SO} 2 \mathrm{eq}$ & $0.092 \mathrm{~kg} \mathrm{CO} 2 \mathrm{eq}$ & $0.963 \mathrm{~kg} \mathrm{PO} 4 \mathrm{eq}$ \\
\hline & & $\begin{array}{l}\text { energy uses for short } \\
\text { rotation willow }\end{array}$ & & & Gasoline use in vehicle & $0.072 \mathrm{~kg} \mathrm{C} 2 \mathrm{H} 4 \mathrm{eq}$ & $0.734 \mathrm{~kg} \mathrm{SO} 2 \mathrm{eq}$ & $0.257 \mathrm{~kg} \mathrm{CO} 2 \mathrm{eq}$ & $0.097 \mathrm{~kg} \mathrm{PO} 4 \mathrm{eq}$ \\
\hline & & $\begin{array}{l}\text { rotation willow } \\
\text { biomass in Sweden }\end{array}$ & & & Bio-heat system & $0.006 \mathrm{~kg} \mathrm{C} 2 \mathrm{H} 4 \mathrm{eq}$ & $0.16 \mathrm{~kg} \mathrm{SO} 2 \mathrm{eq}$ & $35.22 \mathrm{~kg} \mathrm{CO} 2 \mathrm{eq}$ & $0.184 \mathrm{~kg}$ PO4 eq \\
\hline & & & & & Fossil-heat system & $0.003 \mathrm{~kg} \mathrm{C} 2 \mathrm{H} 4 \mathrm{eq}$ & $0.02 \mathrm{~kg} \mathrm{SO} 2 \mathrm{eq}$ & $63.35 \mathrm{~kg} \mathrm{CO} 2 \mathrm{eq}$ & $0.004 \mathrm{~kg} \mathrm{PO} 4 \mathrm{eq}$ \\
\hline \multirow[t]{6}{*}{ Han et al., 2015} & \multirow[t]{6}{*}{ Forestry } & $\begin{array}{l}\text { Assesses the impacts } \\
\text { of forest resource }\end{array}$ & \multirow{6}{*}{$\begin{array}{l}\text { One } \mathrm{m}^{3} \text { of redwood } \\
\log \end{array}$} & \multirow[t]{6}{*}{$\begin{array}{l}\text { From greenhouse grown seedling } \\
\text { to arrival at the mill. }\end{array}$} & $\begin{array}{l}\text { Uneven-aged manual } \\
\text { ground-based }\end{array}$ & $0.31 \mathrm{~g} \mathrm{NOx}$ & $13.55 \mathrm{H}+$ moles & $17.75 \mathrm{~kg} \mathrm{CO} 2 \mathrm{eq}$ & $0.014 \mathrm{~kg} \mathrm{~N}$ eq \\
\hline & & $\begin{array}{l}\text { harvesting in northern } \\
\text { California }\end{array}$ & & & Uneven-aged skyline & $0.3 \mathrm{~g}$ NOx & $12.94 \mathrm{H}+$ moles & $16.96 \mathrm{~kg} \mathrm{CO} 2 \mathrm{eq}$ & $0.013 \mathrm{~kg} \mathrm{~N} \mathrm{eq}$ \\
\hline & & & & & Uneven-aged helicopter & 0.35 g NOx & $17.16 \mathrm{H}+$ moles & $49.89 \mathrm{~kg} \mathrm{CO} 2 \mathrm{eq}$ & $0.016 \mathrm{~kg} \mathrm{~N}$ eq \\
\hline & & & & & $\begin{array}{c}\text { Even-aged manual } \\
\text { ground-based } \\
\text { Even-aged mechanical }\end{array}$ & $0.25 \mathrm{~g} \mathrm{NOx}$ & $10.78 \mathrm{H}+$ moles & $14.2 \mathrm{~kg} \mathrm{CO} 2 \mathrm{eq}$ & $0.011 \mathrm{~kg} \mathrm{~N} \mathrm{eq}$ \\
\hline & & & & & ground-based & 0.29 g NOx & $12.83 \mathrm{H}+$ moles & $16.65 \mathrm{~kg} \mathrm{CO} 2 \mathrm{eq}$ & $0.013 \mathrm{~kg} \mathrm{~N} \mathrm{eq}$ \\
\hline & & & & & Even-aged skyline & $0.26 \mathrm{~g} \mathrm{NOx}$ & $11.14 \mathrm{H}+$ moles & $14.68 \mathrm{~kg} \mathrm{CO} 2 \mathrm{eq}$ & $0.011 \mathrm{~kg} \mathrm{~N} \mathrm{eq}$ \\
\hline
\end{tabular}


Table A1 cont.

\begin{tabular}{|c|c|c|c|c|c|c|c|c|}
\hline Source & Field & Study Subject & Functional Unit & System Boundaries & Scenario & $\begin{array}{c}\text { Photochemical } \\
\text { Ozone Formation }\end{array}$ & Acidification & Global Warming \\
\hline \multirow[t]{9}{*}{$\begin{array}{l}\text { Handler et al., } \\
\quad 2014\end{array}$} & Forestry & $\begin{array}{l}\text { Assessing forestry } \\
\text { supply chain options } \\
\text { in Michigan }\end{array}$ & $\begin{array}{l}\text { One metric tonne of } \\
\text { forest biomass }\end{array}$ & $\begin{array}{l}\text { Feedstock harvesting and } \\
\text { feedstock tranport }\end{array}$ & $\begin{array}{l}\text { Cut-to-length full } \\
\text { processor/forwarder- } \\
30 \% \text { cut } \\
\text { Cut-to-length full }\end{array}$ & - & - & $14.7 \mathrm{~kg} \mathrm{CO} 2 \mathrm{eq}$ \\
\hline & & & & & $\begin{array}{l}\text { processor/forwarder- } \\
70 \% \text { cut } \\
\text { Cut-to-length full }\end{array}$ & - & - & $12.3 \mathrm{~kg} \mathrm{CO} 2 \mathrm{eq}$ \\
\hline & & & & & $\begin{array}{c}\text { processor/forwarder- } \\
\text { Clearcut } \\
\text { Feller- }\end{array}$ & - & - & $9.9 \mathrm{~kg} \mathrm{CO} 2 \mathrm{eq}$ \\
\hline & & & & & $\begin{array}{c}\text { buncher/skidder/slasher- } \\
30 \% \text { cut } \\
\text { Feller- }\end{array}$ & - & - & $26.3 \mathrm{~kg} \mathrm{CO} 2 \mathrm{eq}$ \\
\hline & & & & & $\begin{array}{c}\text { buncher/skidder/slasher- } \\
70 \% \text { cut } \\
\text { Feller- }\end{array}$ & - & - & $19.1 \mathrm{~kg} \mathrm{CO} 2 \mathrm{eq}$ \\
\hline & & & & & $\begin{array}{l}\text { buncher/skidder/slasher- } \\
\text { clearcut }\end{array}$ & - & - & $13.6 \mathrm{~kg} \mathrm{CO} 2 \mathrm{eq}$ \\
\hline & & & & & $\begin{array}{c}\text { Chainsaws/skidder- } \\
30 \% \text { cut }\end{array}$ & - & - & $24.3 \mathrm{~kg} \mathrm{CO} 2 \mathrm{eq}$ \\
\hline & & & & & $\begin{array}{c}\text { Chainsaws/skidder- } \\
70 \% \text { cut }\end{array}$ & - & - & $23.3 \mathrm{~kg} \mathrm{CO} 2 \mathrm{eq}$ \\
\hline & & & & & $\begin{array}{l}\text { Chainsaws/skidder- } \\
\text { clearcut }\end{array}$ & - & - & $22 \mathrm{~kg} \mathrm{CO} 2 \mathrm{eq}$ \\
\hline \multirow{2}{*}{$\begin{array}{l}\text { Gayarre et al., } \\
2015\end{array}$} & \multirow{2}{*}{$\begin{array}{l}\text { Materials } \\
\text { production }\end{array}$} & \multirow{2}{*}{$\begin{array}{l}\text { Concrete kerb } \\
\text { production }\end{array}$} & \multirow{2}{*}{$\begin{array}{l}\text { Producing one } \mathrm{m}^{3} \text { of } \\
\text { concrete }\end{array}$} & \multirow{2}{*}{$\begin{array}{l}\text { Obtaining recycled aggregates, } \\
\text { manufacturing, product use, end of } \\
\text { life }\end{array}$} & Natural Aggregate & $0.69 \mathrm{~kg} \mathrm{C} 2 \mathrm{H} 4 \mathrm{eq}$ & $2278 \mathrm{~kg} \mathrm{SO} 2 \mathrm{eq}$ & $370000 \mathrm{~kg} \mathrm{CO} 2 \mathrm{eq}$ \\
\hline & & & & & Recycled Aggregate & $0.84 \mathrm{~kg} \mathrm{C} 2 \mathrm{H} 4 \mathrm{eq}$ & $2310 \mathrm{~kg} \mathrm{SO} 2 \mathrm{eq}$ & $37500 \mathrm{~kg} \mathrm{CO} 2 \mathrm{eq}$ \\
\hline $\begin{array}{l}\text { Suwanit and } \\
\text { Gheewala, } 2011\end{array}$ & Hydropower & $\begin{array}{l}\text { Investigating the } \\
\text { impacts from mini- } \\
\text { hydropower plants }\end{array}$ & $\begin{array}{l}\text { One MWh } \\
\text { electricity produced }\end{array}$ & Construction and Transportation & $\begin{array}{l}\text { Average of } 5 \text { mini- } \\
\text { hydropower plants }\end{array}$ & $5.02 \mathrm{~kg} \mathrm{C} 2 \mathrm{H} 4 \mathrm{eq}$ & $88.49 \mathrm{~kg} \mathrm{SO} 2 \mathrm{eq}$ & $17.62 \mathrm{~kg} \mathrm{CO} 2 \mathrm{eq}$ \\
\hline \multirow[t]{2}{*}{ Zhang et al., 2014} & \multirow[t]{2}{*}{ Hydropower } & $\begin{array}{l}\text { Quantifying the carbon } \\
\text { footprint of two } \\
\text { different types of }\end{array}$ & One $\mathrm{kWh}$ of & $\begin{array}{l}\text { Materials production, transport of } \\
\text { suppies, construction, operation }\end{array}$ & Concrete dam & - & - & $1169.2510^{4} \mathrm{tCO} 2 \mathrm{eq}$ \\
\hline & & hydropower dams & production & and maintance & Rockfill dam & - & - & $879.95104 \mathrm{tCO} 2 \mathrm{eq}$ \\
\hline
\end{tabular}


Table A2. Table of Parameters used in the AS, PS, and MT.

\begin{tabular}{|c|c|c|c|c|c|c|c|c|c|c|c|}
\hline \multicolumn{6}{|c|}{ Phase I } & \multicolumn{6}{|c|}{ Phase II } \\
\hline Parameter & Baseline & $\begin{array}{l}\text { Alder } \\
50 \%\end{array}$ & $\begin{array}{l}\text { Alder } \\
100 \%\end{array}$ & $\begin{array}{c}\text { Plant } \\
\text { Sourcing }\end{array}$ & $\begin{array}{c}\text { Materials } \\
\text { Transportation }\end{array}$ & Parameter & Baseline & $\begin{array}{l}\text { Alder } \\
50 \%\end{array}$ & $\begin{array}{l}\text { Alder } \\
100 \%\end{array}$ & $\begin{array}{c}\text { Plant } \\
\text { Sourcing }\end{array}$ & $\begin{array}{c}\text { Materials } \\
\text { Transportation }\end{array}$ \\
\hline Granite Boulder & 4 & 2 & 0 & 4 & 4 & Granite Boulder Backhaul & 114 & 114 & 0 & 114 & 228 \\
\hline Granite Boulder Backhaul & 40 & 40 & 0 & 40 & 80 & Granite Boulder & 4 & 2 & 0 & 4 & 4 \\
\hline Granite Boulder Transport & 4 & 2 & 0 & 4 & 4 & Granite Boulder Transport & 4 & 2 & 0 & 4 & 4 \\
\hline Granite Boulder Transport Distance & 40 & 40 & 0 & 40 & 80 & Granite Boulder Transport Distance & 114 & 114 & 0 & 114 & 228 \\
\hline Honda Generator & 8 & 4 & 0 & 8 & 8 & Honda Generator & 9 & 4.5 & 0 & 9 & 9 \\
\hline Hyundai Excavator Hours & 25 & 12.5 & 6.25 & 25 & 25 & Rootwad Excavation & 2 & 1 & 0 & 2 & 2 \\
\hline Rootwad Excavation & 2 & 1 & 0 & 2 & 2 & John Deere Excavator Hours & 20 & 10 & 5 & 20 & 20 \\
\hline Metal Coupler Production & 8 & 4 & 0 & 8 & 8 & Metal Coupler Backhaul & 14 & 14 & 0 & 14 & 28 \\
\hline Metal Coupler Backhaul & 14 & 14 & 0 & 14 & 28 & Metal Coupler Production & 8 & 4 & 0 & 8 & 8 \\
\hline Metal Coupler Transport Distance & 14 & 14 & 0 & 14 & 28 & Metal Coupler Transport Distance & 14 & 14 & 0 & 14 & 28 \\
\hline Redwood Backhaul & 33 & 33 & 0 & 33 & 66 & Redwood Backhaul & 33 & 33 & 0 & 33 & 66 \\
\hline Redwood Harveted & 4 & 2 & 0 & 4 & 4 & Redwood Harveted & 4 & 2 & 0 & 4 & 4 \\
\hline Redwood Transport & 4 & 2 & 0 & 4 & 4 & Redwood Transport & 4 & 2 & 0 & 4 & 4 \\
\hline Redwod Tranportation Distance & 33 & 33 & 0 & 33 & 66 & Redwod Tranportation Distance & 33 & 33 & 0 & 33 & 66 \\
\hline Rootwad Backhaul & 33 & 33 & 0 & 33 & 38 & Rootwad Backhaul & 19 & 19 & 0 & 19 & 38 \\
\hline Rootwad Transport & 4 & 2 & 0 & 19 & 4 & Rootwad Transport & 4 & 2 & 0 & 4 & 4 \\
\hline Rootwad Tranport Distance & 19 & 19 & 0 & 19 & 38 & Rootwad Tranport Distance & 19 & 19 & 0 & 19 & 38 \\
\hline Case Backhoe Hours & 16 & 16 & 16 & 0 & 16 & Case Backhoe Hours & 8 & 8 & 8 & 0 & 8 \\
\hline Nursery Plant Transport & 0 & 0 & 0 & 180720 & 0 & Nursery Plant Backhaul & 0 & 0 & 0 & 36 & 0 \\
\hline Nursery Plant Backhaul & 0 & 0 & 0 & 36 & 0 & Nursery Plant Transport & 0 & 0 & 0 & 86400 & 0 \\
\hline Nursery Seedlineg & 0 & 0 & 0 & 1255 & 0 & Nursery Seedlineg & 0 & 0 & 0 & 600 & 0 \\
\hline Plant Backhaul & 42 & 42 & 42 & 0 & 42 & Plant Backhaul & 14 & 14 & 14 & 0 & 14 \\
\hline Plant Hualing & 42000 & 42000 & 42000 & 0 & 42000 & Plant Hualing & 2800 & 2800 & 2800 & 0 & 2800 \\
\hline
\end{tabular}


Table A3. Phase I sensitivity analysis results.

\begin{tabular}{|c|c|c|c|c|c|c|c|c|c|c|c|}
\hline Phase I - 25\% Reduction & Baseline & GB-3 & GBBH-30 & GBT-3 & GBTRAN-3 & HGEN-6 & HYEX-18.75 & HYEXROOT-1.5 & MC-6.0 & мСвн-10.5 & MCTRAN-10.5 \\
\hline Human Health- Non-Carcinogenics (CTUh) & $2.64 \mathrm{E}-06$ & $2.60 \mathrm{E}-06$ & $2.64 \mathrm{E}-06$ & $2.60 \mathrm{E}-06$ & $2.60 \mathrm{E}-06$ & $2.64 \mathrm{E}-06$ & $2.49 \mathrm{E}-06$ & & & & \\
\hline Human Health-Carcinogenics (CTUh) & $1.77 \mathrm{E}-06$ & $1.75 \mathrm{E}-06$ & $1.77 \mathrm{E}-06$ & $1.76 \mathrm{E}-06$ & $1.76 \mathrm{E}-06$ & $1.77 \mathrm{E}-06$ & $1.62 \mathrm{E}-06$ & $1.76 \mathrm{E}-06$ & $1.71 \mathrm{E}-06$ & $1.77 \mathrm{E}-06$ & $1.77 \mathrm{E}-06$ \\
\hline Photochemical Ozone Formation (kg 03 eq) & 6.47 & 6.44 & 6.47 & 6.43 & 6.43 & 6.47 & 5.9 & 6.43 & 6.46 & 6.47 & 6.47 \\
\hline Resource Depletion-Fossil Fuels (MJ surplus) & 118.57 & 118.12 & 118 & 118.06 & 118 & 118.46 & 106.7 & 117.63 & 118.35 & 118.54 & 118.54 \\
\hline Respiratory Effects (kg PM2.5) & 0.025 & 0.025 & 0.0253 & 0.025 & 0.0252 & 0.025 & 0.023 & 0.025 & 0.025 & 0.025 & 0.025 \\
\hline Ozone Depletion (kg CFC-11 eq) & 1.41E-05 & $1.41 \mathrm{E}-05$ & $1.41 \mathrm{E}-05$ & 1.40E-05 & $1.40 \mathrm{E}-05$ & $1.40 \mathrm{E}-05$ & $1.30 \mathrm{E}-05$ & $1.39 \mathrm{E}-05$ & $1.41 \mathrm{E}-05$ & $1.41 \mathrm{E}-05$ & 1.41E-05 \\
\hline Ecotoxicity (CTUe) & 77.27 & 76.180 & 77.20 & 76.57 & 76.57 & 77.23 & 72.64 & 76.9 & 74.53 & 77.19 & 77.19 \\
\hline Acidification (kg SO2 eq) & 0.26 & 0.26 & 0.263 & 0.26 & 0.261 & 0.26 & 0.24 & 0.26 & 0.26 & 0.26 & 0.26 \\
\hline $\begin{array}{l}\text { Global Warming }\left(\mathrm{kg} \mathrm{CO}^{\text {Geq }}\right) \\
\text { Eutrophication }(\mathrm{kg} \mathrm{N} \mathrm{eq})\end{array}$ & $\begin{array}{l}109.42 \\
00632\end{array}$ & 109.15 & 109.43 & 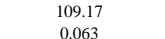 & 109.17 & 109.37 & 103.43 & 108.95 & 109.16 & 109.41 & 109.41 \\
\hline $\begin{array}{l}\text { Eutrophication }(\mathrm{kg} \mathrm{N} \mathrm{eq}) \\
\text { Total }\end{array}$ & 0.063 & $\begin{array}{r}0.063 \\
\mathbf{3 0 2 4} \\
\end{array}$ & 0.063 & $\begin{array}{c}0.063 \\
\mathbf{3 0 5 8}\end{array}$ & 0.063 & 0.063 & 0.059 & 0.063 & 0.062 & 0.063 & $\frac{0.0637}{31.96}$ \\
\hline $\begin{array}{l}\text { Total } \\
\quad \text { Phase I- 25\% Reduction } \\
\end{array}$ & $\begin{array}{c}312.08 \\
\text { REDWBH-24.75 }\end{array}$ & $\begin{array}{c}310.24 \\
\text { REDW-3.0 }\end{array}$ & $\begin{array}{l}311.45 \\
\text { REDWT-3.0 }\end{array}$ & $\begin{array}{c}310.58 \\
\text { REDWTRAN-24.75 }\end{array}$ & $\begin{array}{c}310.52 \\
\text { ROOTBH-14.25 }\end{array}$ & $\begin{array}{c}311.88 \\
\text { ROOTT-3.0 }\end{array}$ & $\begin{array}{l}2888.99 \\
\text { ROOTRAN-14.5 }\end{array}$ & $\begin{array}{l}310.26 \\
\text { CBH-12 }\end{array}$ & $\begin{array}{l}3088.85 \\
\text { VEGBAK } 10.5\end{array}$ & $\begin{array}{l}3311.96 \\
\text { VEGHAUL-31500 }\end{array}$ & 311.96 \\
\hline Human Health- Non-Carcinogenics (CTUh) & $2.64 \mathrm{E}-06$ & $2.69 \mathrm{E}-06$ & $2.62 \mathrm{E}-06$ & $2.62 \mathrm{E}-06$ & $2.40 \mathrm{E}-06$ & $2.64 \mathrm{E}-06$ & $2.64 \mathrm{E}-06$ & $2.58 \mathrm{E}-06$ & $2.64 \mathrm{E}-06$ & $2.64 \mathrm{E}-06$ & \\
\hline Human Health-Carcinogenics (CTUh) & $1.77 \mathrm{E}-06$ & $1.76 \mathrm{E}-06$ & $1.77 \mathrm{E}-06$ & $1.76 \mathrm{E}-06$ & $1.77 \mathrm{E}-06$ & $1.77 \mathrm{E}-06$ & $1.77 \mathrm{E}-06$ & $1.71 \mathrm{E}-06$ & $1.77 \mathrm{E}-06$ & $1.77 \mathrm{E}-06$ & \\
\hline Photochemical Ozone Formation $(\mathbf{k g} 03$ eq) & 6.47 & 6.41 & 6.44 & 6.44 & 6.47 & 6.47 & 6.47 & 6.26 & 6.47 & 6.47 & \\
\hline Resource Depletion-Fossil Fuels (MJ surplus) & 118 & 118.07 & 118.14 & 118.13 & 118.57 & 118.51 & 118.51 & 114.15 & 118.57 & 118.54 & \\
\hline Respiratory Effects (kg PM2.5) & 0.025 & 0.025 & 0.025 & 0.025 & $2.53 \mathrm{E}-02$ & 0.025 & $2.53 \mathrm{E}-02$ & 0.024 & 0.025 & 0.025 & \\
\hline Ozone Depletion (kg CFC-11 eq) & $1.41 \mathrm{E}-05$ & $1.41 \mathrm{E}-05$ & $1.40 \mathrm{E}-05$ & $1.40 \mathrm{E}-05$ & $1.41 \mathrm{E}-05$ & $1.41 \mathrm{E}-05$ & $1.41 \mathrm{E}-05$ & $1.35 \mathrm{E}-05$ & $1.41 \mathrm{E}-05$ & $1.41 \mathrm{E}-05$ & \\
\hline Ecotoxicity (CTUe) & 77.27 & 76.97 & 76.67 & 76.67 & 77.27 & 77.18 & 77.18 & 75.54 & 77.27 & 77.21 & \\
\hline Acidification (kg SO2 eq) & 0.26 & 0.26 & 0.26 & 0.26 & 0.26 & 0.26 & 0.26 & 0.25 & 0.26 & 0.26 & \\
\hline Global Warming $(\mathrm{kg} \mathrm{CO} 2$ eq) & 109.42 & 97 & 109.21 & 109.21 & 109.42 & 109.4 & 109.39 & 107.19 & 109.42 & 109.41 & \\
\hline $\begin{array}{l}\text { Eutrophication (kg Neq) } \\
\text { Total }\end{array}$ & $\frac{0.0637}{311.51}$ & $\frac{0.063}{298.80}$ & $\frac{0.063}{310.81}$ & $\begin{array}{l}0.063 \\
310.80\end{array}$ & $\frac{0.063}{312.08}$ & $\frac{0.063}{311.91}$ & $\frac{0.063}{311.90}$ & $\frac{0.061}{303.48}$ & $\frac{6.372-02}{312.08}$ & $\frac{0.063}{311.98}$ & \\
\hline
\end{tabular}

Table A4. Phase II sensitivity analysis results.

\begin{tabular}{|c|c|c|c|c|c|c|c|c|c|c|c|}
\hline Phase II- $25 \%$ Reduction & Baseline & GBHH-85.5 & GBII-3 & GBTIL-3 & GBTRANNII-85.5 & HGENII-6.75 & JDEX-15 & HYЕХRОOТI-1.5 & МСВНІІ-10.5 & MCH-6.0 & MCTRANII-10.5 \\
\hline Human Health- Non-Carcinogenics (CTUh) & $2.50 \mathrm{E}-06$ & $2.50 \mathrm{E}-06$ & $2.43 \mathrm{E}-06$ & $2.38 \mathrm{E}-06$ & $2.38 \mathrm{E}-06$ & $2.49 \mathrm{E}-0.05$ & & & $2.49 \mathrm{E}-06$ & $2.37 \mathrm{E}-0.06$ & \\
\hline Human Health-Carcinogenics (CTUh) & $1.20 \mathrm{E}-06$ & $1.20 \mathrm{E}-06$ & $1.18 \mathrm{E}-06$ & $1.17 \mathrm{E}-06$ & $1.17 \mathrm{E}-06$ & $1.20 \mathrm{E}-06$ & $1.18 \mathrm{E}-06$ & $1.18 \mathrm{E}-06$ & $1.20 \mathrm{E}-06$ & $1.13 \mathrm{E}-06$ & $1.20 \mathrm{E}-06$ \\
\hline Photochemical Ozone Formation (kg O3 eq) & 4.39 & 4.39 & 4.33 & 4.21 & 4.2 & 4.38 & 4.3 & 4.34 & 4.39 & 4.38 & 4.39 \\
\hline Resource Depletion-Fossil Fuels (MJ surplus) & 64.63 & 64.63 & 63.9 & 62.3 & 62.29 & 64.47 & 62.99 & 63.41 & 64.59 & 64.34 & 64.59 \\
\hline Respiratory Effects (kg PM2.5) & 0.018 & $1.87 \mathrm{E}-02$ & 0.018 & 0.018 & 0.017 & 0.018 & 0.018 & 0.018 & 0.018 & 0.018 & 0.018 \\
\hline Ozone Depletion (kg CFC-11 eq) & $7.65 \mathrm{E}-06$ & $7.65 \mathrm{E}-06$ & $7.56 \mathrm{E}-04$ & $7.37 \mathrm{E}-06$ & $7.37 \mathrm{E}-06$ & 7.63E-06 & $7.45 \mathrm{E}-06$ & $7.51 \mathrm{E}-06$ & $7.64 \mathrm{E}-06$ & $7.62 \mathrm{E}-06$ & $7.64 \mathrm{E}-06$ \\
\hline $\begin{array}{l}\text { Ecotoxicity (CTUe) } \\
\text { Acidifiction (k SO2 eq) }\end{array}$ & $\begin{array}{l}70.66 \\
0.17\end{array}$ & $\begin{array}{l}70.66 \\
0.17\end{array}$ & $\begin{array}{l}68.92 \\
0.17\end{array}$ & $\begin{array}{c}67.48 \\
0.17\end{array}$ & 67.48 & 70.6 & 70.03 & 70.19 & 70.56 & 67.16 & 70.56 \\
\hline $\begin{array}{l}\text { Acidificiation (kg SO SO eq) } \\
\text { Glibal Warming } \mathbf{k g} \text { cO2 eq) }\end{array}$ & $\begin{array}{c}0.17 \\
9601\end{array}$ & $\begin{array}{c}0.17 \\
9601\end{array}$ & $\begin{array}{l}0.17 \\
0.58\end{array}$ & $\begin{array}{l}0.17 \\
9488\end{array}$ & 0.016 & $\begin{array}{l}0.17 \\
0593\end{array}$ & 0.17 & $\begin{array}{l}0.17 \\
054\end{array}$ & $\begin{array}{l}0.17 \\
0909\end{array}$ & 0.17 & $\begin{array}{l}0.17 \\
0999\end{array}$ \\
\hline 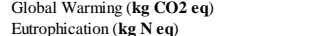 & $\begin{array}{c}96.01 \\
7.66 \mathrm{E}-06\end{array}$ & $\begin{array}{l}96.01 \\
0.045\end{array}$ & $\begin{array}{l}95.58 \\
0.044\end{array}$ & $\begin{array}{r}94.88 \\
0.044\end{array}$ & $\begin{array}{l}94.87 \\
0.043\end{array}$ & $\begin{array}{l}95.93 \\
0.045\end{array}$ & $\begin{array}{l}95.19 \\
0.044\end{array}$ & $\begin{array}{c}95.4 \\
0044\end{array}$ & $\begin{array}{r}95.99 \\
0.042\end{array}$ & $\begin{array}{r}95.68 \\
0.043\end{array}$ & $\begin{array}{r}95.99 \\
0.94\end{array}$ \\
\hline Total & 2335.88 & 235.92 & 2332.96 & 0.044 & 228.92 & $\frac{0.043}{235.61}$ & $\begin{array}{l}0.044 \\
232.74\end{array}$ & 0.044 & 235.76 & 231.79 & $\frac{0.045}{235.76}$ \\
\hline Phase II - $25 \%$ Reduction & REDWBHII-24.75 & REDWII-3.0 & REDWTII-3.0 & REDWTRANII-24.75 & ROOTBHII-14.25 & ROOTTII-3.0 & ROOTTRANII-14.25 & СBHII-6 & VEGBACK 10.5 & VEGHAUL-21000 & \\
\hline Human Health- Non-Carcinogenics (CTUh) & $2.50 \mathrm{E}-06$ & $2.49 \mathrm{E}-06$ & $2.45 \mathrm{E}-06$ & $2.47 \mathrm{E}-06$ & $2.50 \mathrm{E}-06$ & $2.47 \mathrm{E}-06$ & $2.49 \mathrm{E}-06$ & $2.45 \mathrm{E}-06$ & $2.51 \mathrm{E}-06$ & $2.50 \mathrm{E}-06$ & \\
\hline Human Health-Carcinogenics (CTUh) & $1.20 \mathrm{E}-06$ & $1.19 \mathrm{E}-06$ & $1.17 \mathrm{E}-06$ & $1.19 \mathrm{E}-06$ & $1.20 \mathrm{E}-06$ & $1.18 \mathrm{E}-06$ & $1.20 \mathrm{E}-06$ & $1.15 \mathrm{E}-06$ & $1.20 \mathrm{E}-06$ & $1.20 \mathrm{E}-06$ & \\
\hline Photochemical Ozone Formation (kg O3 eq) & 4.39 & 4.31 & 4.25 & 4.35 & 4.36 & 4.29 & 4.39 & & 4.4 & 4.4 & \\
\hline Resource Depletion-Fossil Fuels (MJ surplus) & 64.63 & 63.98 & 62.43 & 64.07 & 64.63 & 62.91 & 64.55 & 60.83 & 64.74 & 64.71 & \\
\hline Respiratory Effects (kg PM2.5) & 0.018 & 0.018 & 0.018 & 0.018 & 0.018 & 0.018 & 0.018 & 0.018 & 0.018 & 0.018 & \\
\hline Ozone Depletion (kg CFC-11 eq) & $7.65 \mathrm{E}-06$ & $7.57 \mathrm{E}-06$ & 7.39E- -06 & $7.58 \mathrm{E}-06$ & $7.65 \mathrm{E}-06$ & $7.44 \mathrm{E}-06$ & $7.64 \mathrm{E}-06$ & $7.19 \mathrm{E}-06$ & $7.66 \mathrm{E}-06$ & $7.66 \mathrm{E}-06$ & \\
\hline Ecotoxicity (CTUe) & 70.66 & 70.28 & 69.26 & 69.9 & 70.66 & 69.92 & 70.55 & 69.18 & 70.9 & 70.83 & \\
\hline Acidification (kg SO2 eq) & 0.17 & 0.17 & 0.17 & 0.17 & 0.17 & 0.17 & 0.17 & 0.16 & 0.17 & 0.17 & \\
\hline $\begin{array}{l}\text { Global Warming }(\mathrm{kg} \text { CO2 eq) } \\
\text { Futrontication }\end{array}$ & 96.01 & $\begin{array}{l}80.11 \\
0.04\end{array}$ & 94.9 & 95.74 & 96.01 & 95.15 & 95.98 & 94.09 & 96.08 & 96.06 & \\
\hline $\begin{array}{l}\text { Eutrophication }(\mathrm{kg} \mathrm{N} \mathrm{eq)} \\
\text { Total }\end{array}$ & $\begin{array}{l}0.0455 \\
235.92\end{array}$ & $\begin{array}{r}0.044 \\
21891\end{array}$ & $\begin{array}{r}0.0 .04 \\
231.07\end{array}$ & $\begin{array}{r}0.0 .04 \\
234.29\end{array}$ & $\begin{array}{c}0.045 \\
235.89\end{array}$ & $\begin{array}{r}0.044 \\
23250\end{array}$ & $\begin{array}{c}0.045 \\
2350\end{array}$ & $\begin{array}{r}0.043 \\
2228.53\end{array}$ & $\begin{array}{r}0.043 \\
232535\end{array}$ & $\begin{array}{c}0.045 \\
22363\end{array}$ & \\
\hline
\end{tabular}


Table A5. Sample LCA field data form.

\begin{tabular}{l} 
LCA Field Data Form \\
River Restoration \\
\begin{tabular}{|l|l|l|l|l|}
\hline Monitor Name: & \multicolumn{3}{|c|}{} \\
\hline Construction & Equipment Model & Equipment Type & Engine Power & Operating Hours \\
\hline Activity Overview: & & \\
& & & \\
Activity Purpose: & & & \\
& &
\end{tabular} \\
\hline
\end{tabular}

\begin{tabular}{|l|l|l|l|l|}
\hline Transportation & Equipment Model & Truck Type & Haul Distance & Haul Weight \\
\hline Activity Overview: & \multicolumn{4}{|c|}{} \\
& & & & \\
Activity Purpose: & & & & \\
& & \\
\hline
\end{tabular}

\begin{tabular}{|l|c|c|c|}
\hline Raw Material & Material Type & Weight & Material Source \\
\hline Activity Overview: & & & \\
Activity Pupose: & & & \\
& & & \\
& & \\
\hline
\end{tabular}

